Portland State University

PDXScholar

6-21-1994

\title{
English Language Teaching and Curricula in the People's Republic of China
}

Kirsten Nadia Ngan

Portland State University

Follow this and additional works at: https://pdxscholar.library.pdx.edu/open_access_etds

Part of the Bilingual, Multilingual, and Multicultural Education Commons Let us know how access to this document benefits you.

\section{Recommended Citation}

Ngan, Kirsten Nadia, "English Language Teaching and Curricula in the People's Republic of China" (1994). Dissertations and Theses. Paper 4800.

https://doi.org/10.15760/etd.6683

This Thesis is brought to you for free and open access. It has been accepted for inclusion in Dissertations and Theses by an authorized administrator of PDXScholar. Please contact us if we can make this document more accessible: pdxscholar@pdx.edu. 


\section{THESIS APPROVAL}

The abstract and thesis of Kirsten Nadia Ngan for the Masters of Arts in Teaching English to Speakers of Other Languages were presented June 21, 1994, and accepted by the thesis committee and the department.

COMMITTEE APPROVAL
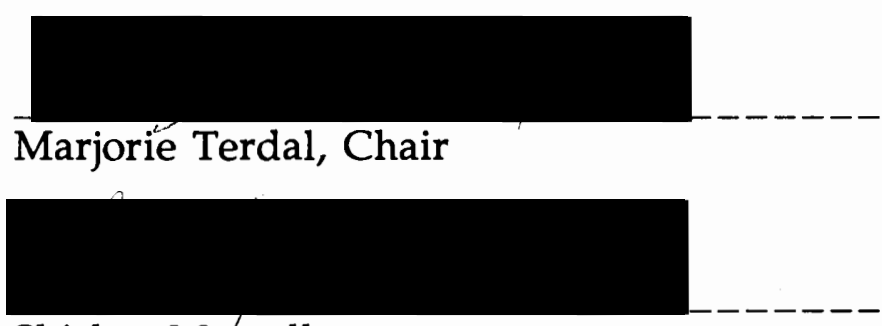

Shirley Morrell

DEPARTMENT APPROVAL:

James R. Nattinger, Chair

Jonathan Pease

Nancy Benson

Representative of the Office of Graduate Studies
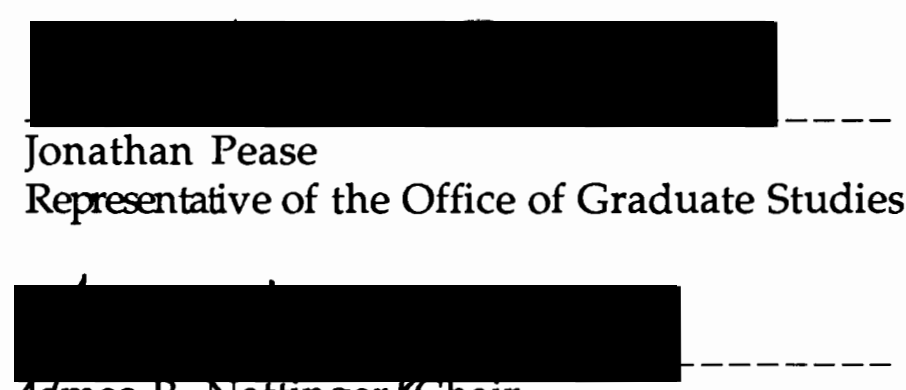

pepartment of Applied Linguistics

$* * * * * * * * * * * * * * * * * * * * * * * * * * * * * * * * * * * * * * * * * * * * * * * * * * * * * * * * * * * * * * * * * * * * * * * *$

ACCEPTED FOR PORTLAND STATE UNIVERSITY BY THE LIBRARY

by

on

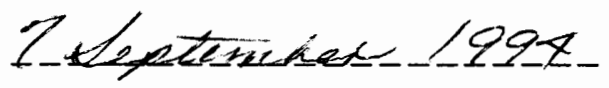




\begin{abstract}
An abstract of the thesis of Kirsten Nadia Ngan for the Masters of Arts in Teaching English to Speakers of Other Languages presented June 21, 1994.

Title: $\quad$ English Language Teaching and Curricula in the People's Republic of China.
\end{abstract}

Since China's open-door policy of 1978, an increasing number of Western language teachers have entered the People's Republic. Numerous reports criticizing Chinese teaching methods, books, curricula, and students have been written by teachers of English, the cause of which can, in many cases, be related back to teachers' different expectations about language curricula.

Dubin and Olshtain's (1986) curriculum framework was utilized in this study to examine the premises of language learning and teaching in China. A questionnaire was sent to teachers and students at seven schools in the People's Republic of China. The questionnaire included a brief needs analysis and questions related to views about language, language learning and education. Data from the 347 student respondents and 34 teacher respondents were used to discuss (i) the priorities of English language teachers and learners in China, and (ii) whether Western methodologies were suitable for use in China. 
The conclusions drawn from the study were, firstly, that Chinese language teachers and learners rank product over process. Linked to this was the conclusion that no one Western methodology was particularly suitable or unsuitable for use in China. Secondly, it appeared that students in China prioritize passive language skills and passive ways of learning over active language skills and active methods of learning. 


\title{
ENGLISH LANGUAGE TEACHING AND CURRICULA \\ IN THE PEOPLE'S REPUBLIC OF CHINA
}

\author{
by \\ KIRSTEN NADIA NGAN
}

A thesis submitted in partial fulfillment of the requirements for the degree of

\author{
MASTER OF ARTS \\ in \\ TEACHING ENGLISH TO SPEAKERS OF OTHER LANGUAGES
}

Portland State University

1994 


\section{ACKNOWLEDGMENTS}

Thank you Dr. Terdal for your supervision of this study, in particular your help with the peculiarities of American English, punctuation, and for promptly returning different drafts as they meandered in. By the way, did you know that 'MA TESOL thesis' is an anagram of 'Oh I'm tasteless'. Thanks also to my other advisors: Nancy Benson, Shirley Morrell, and Jonothan Pease for their suggestions and encouragement.

This thesis would have been very difficult to complete without the assistance of those teachers and students in China who responded to the questionnaires. Thank you all for participating. Thanks also to Monica Emi and several Chinese friends from the International Coffee House and PSU for translating and editing the Chinese questionnaire.

John Gaines made sense of what seemed like screeds of numbers and proofread chapter IV to ensure that no incorrect assumptions were made. Your help was invaluable. A special thanks to Dad. Your clear thinking and directional comments assisted me to tighten the sections and to ensure that the route taken wasn't completely haphazard.

Thanks heaps Phillip. Thank you for reassuring me that I wasn't going crazy, cooking, providing advice, hours of data entry, analyzing and explaining the statistics, and editing \& re-editing my droll drafts.

And certainly my pen wouldn't even have been lifted without the breath of life given from the one reminding me... 
Why spend money on what is not bread, and your labor on what does not satisfy?

Listen, listen to me, and eat what is good, and your soul will delight in the richest of fare.

Give ear and come to me;

hear me, that your soul may live. (Isaiah 55: 2-3) 
TABLE OF CONTENTS

PAGE

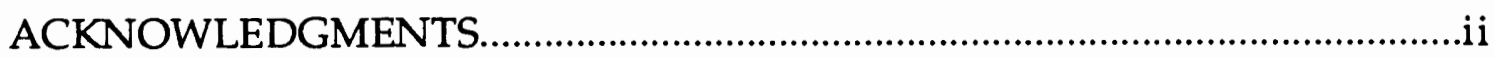

LIST OF TABLES ........................................................................................................

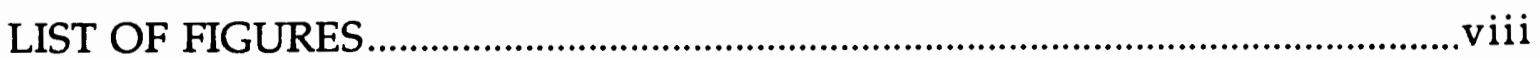

\section{CHAPTER}

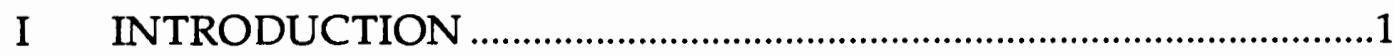

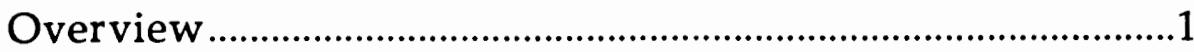

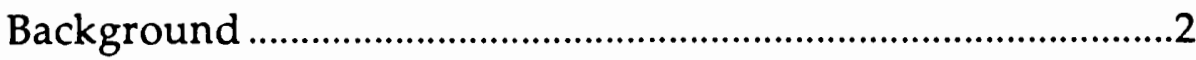

Western Language Teachers in China ...................................

Explanations for Dissatisfaction.............................................

Research Questions .......................................................................

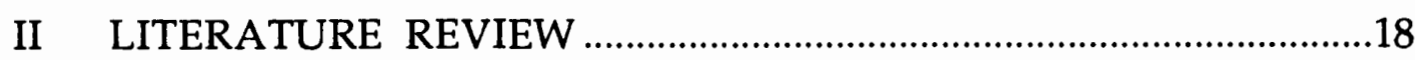

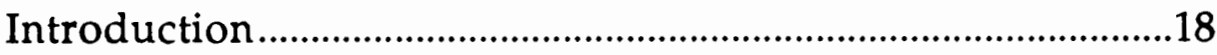

An Overview of the History of China........................................18

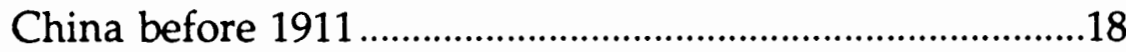

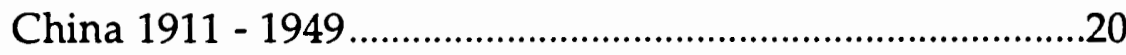

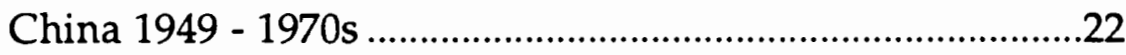

China 1970s to the present ...................................................23

Values held in Chinese society ............................................24

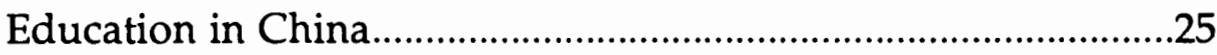

Views about Education in China..........................................35

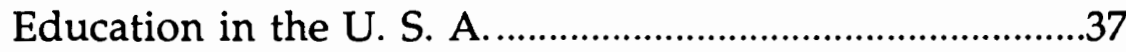

Views about Language.....................................................................41

English Language Teaching ....................................................43

History of English Language Teaching in China ..............46 


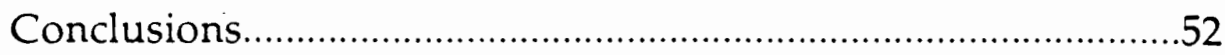

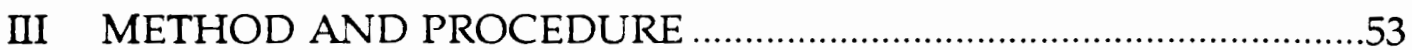

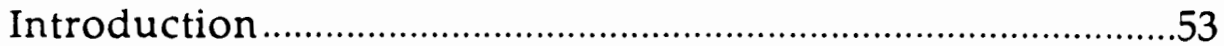

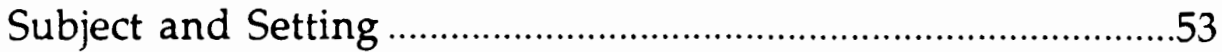

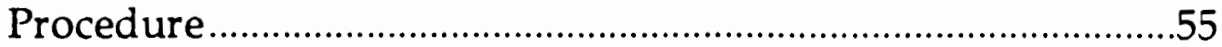

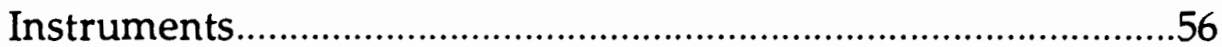

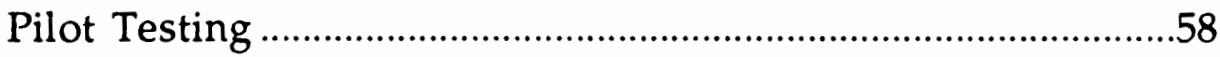

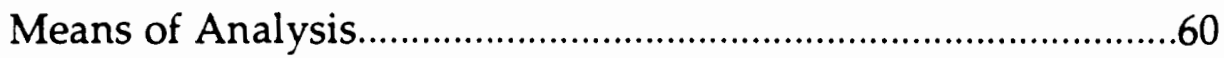

Description of Statistical Tests.......................................................60

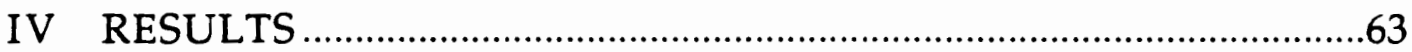

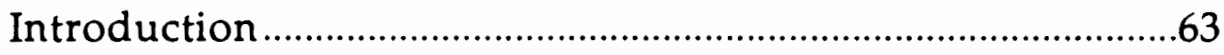

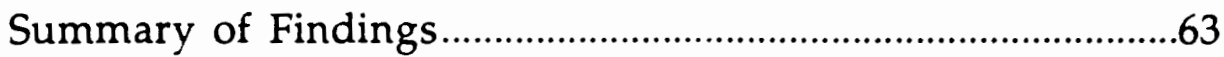

Demographic Data .................................................................63

Preferred Teachers and Methods...................................................66

The Importance and Use of Language ...............................71

Views about Language, Language Learning and

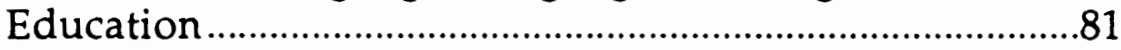

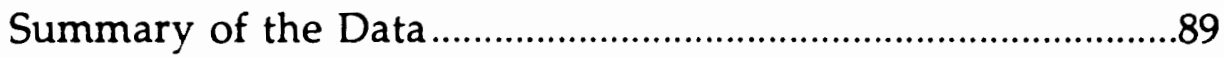

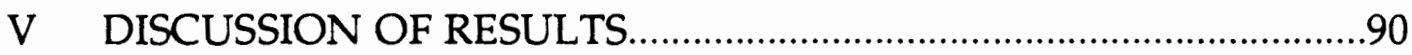

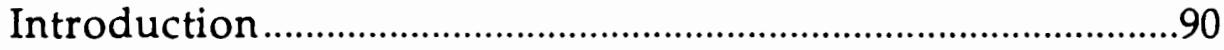

Discussion of Research Questions...............................................90

imitations of this Study ..............................................................103

Dubin and Olshtain's Framework ............................................104

Implications for Teaching in China/ Curriculum

Development ................................................................................109

Suggestions for Further Research ...............................................111

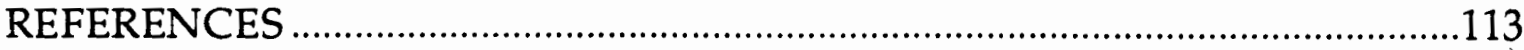


APPENDICES

A GUIDELINES FOR THE DEVELOPMENT OF THE QUESTIONNAIRE 119

B CONSENT FORM AND QUESTIONNAIRES .................................126

C CORRESPONDENCE WITH COORDINATORS 139

D VARIATION BETWEEN DEMOGRAPHIC GROUPS RESPONSES TO QUESTIONNAIRE ITEMS 142

E TYPES OF QUESTIONS TO ASK ALONGSIDE OR INSTEAD OF QUESTIONS 41-62 


\section{LIST OF TABLES}

TABLE

I Stages, Decision-Making Roles and Products in Curriculum Development ............................................. 14

II A Summary of Chinese History before 1911............... 19

III A Comparison of the Values Attributed to

Education in America and China ................................. 40

IV An Overview of Historical Events, Education, and

Language Teaching in China, and Western

Language Teaching Methods .......................................... 48

V Values Underlying Questionnaire Items 41 to $62 \ldots . . .59$

VI Demographic Characteristics of Respondents............. 64

VII Teachers and Students Self Evaluation of English

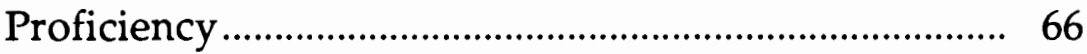

VIII Demographic Data by University ................................. 67

IX Factors for Questions 25a-40a: Importance Scale ........ 75

$X \quad$ Derived Factors from Student and Teacher

Responses for Questions 25-40...................................... 77

XI Rank Order of the Means of Questions 41-62 from

Most Agreement to Least Agreement............................ 83

XII Responses to Questions 41-62 by Conceptual

Framework and Subject Groups......................................... 


\section{LIST OF FIGURES}

FIGURE

1 Factors Influencing Curriculum

2 Map of China Showing Provincial Boundaries and the Cities Where the Seven Universities are Situated

3 Mean responses of Teachers and Students to Questions 13-24 68

4 Preferences for Teacher and Method by School 71

5 Teachers and Students Mean Responses to Questions $25 a-40 a$

6 Teachers and Students Mean Responses to Questions $25 \mathrm{~b}-40 \mathrm{~b}$.

7 A Comparison of the Frequency Means and Importance Means from all Respondents for Questions 25-40

8 Mean Responses to Questions 25-40 Factor Groupings by School

9 Teachers and Students Mean Responses to the Factor Groupings of Questions 25-40

10 Mean Responses of Students and Teachers for Questions 41-62

11 Mean Response of Teachers and Students to Questions 41-62 Ordered by Students' Agreement to Items Within the Conceptual Groupings 85

12 Summary of the Questionnaire Information Using

Dubin and Olshtain's (1986) Framework for Curriculum Design 


\section{CHAPTER I}

\section{INTRODUCTION}

\section{OVERVIEW}

Since the late 1970's, educators in the field of teaching English to speakers of other languages (TESOL) have heavily debated the appropriateness of the teaching methods, learners' strategies, text books and curricula used in China for teaching English, with particular reference to how the Chinese methods contrast with Western methods ${ }^{1}$, notably the communicative approach. (The communicative approach asserts that a language exists for the purpose of communication. The approach stresses use of the target language and the conveyance of meaning over grammatical form.)

Briefly, as China opened to the West, and to Western teachers of English in December 1978, the foreign language teachers compared the education systems of China and their home countries. These evaluations tended to be subjective and critical. The result was that several questions were raised about the appropriateness of various methodologies, learning

${ }^{1}$ Western methods is a phrase that has been used in many TESOL publications to refer to methods and ideas that have been articulated in the non-communist countries of Europe and their progeny. This paper follows this usage but acknowledges that the ideas labeled Western are not necessarily unique to Western countries. 
strategies, and learning styles in China. These questions of appropriateness do not appear to have been conclusively answered over the last decade.

Dubin and Olshtain (1986) present a framework from which one can analyze the debate about language training in China. They posit that a language program is influenced by its setting, the patterns of language use in society, the political and national context and group and individual attitudes (p. 6). In turn the curriculum of the program is influenced by viewpoints on the nature of language, the nature of language learning and educationalcultural viewpoints (p. 34). Hence a language curriculum tends to be the culmination of a society's educational views. In the case of the above debate, it is likely that the educational views and expectations of policy makers, teachers, and students in China compared with their counterparts in the United States of America are the cause of 'incompatible' differences.

The study presented in this thesis used Dubin and Olshtain's framework to look at issues raised in the debate over language teaching methods in China. A needs analysis was used to elucidate the views of language teachers and students in China. From this needs analysis, the ways that English is used in China and the participants' views about language learning were compared with those promoted by Western teachers, methodologists and curricula.

\section{BACKGROUND}

The catalysts of this study were comments about Chinese language learners in several journal articles. These articles concentrated around two themes: first, that Chinese learners of English were in some way different from other 
learners; and second, that the methods used to teach Chinese learners were different from those used to teach other learners. Chinese learners were thought to differ from others in several ways. One Western teacher of English in China who exemplifies the belief that Chinese students learn a language in a different order from other learners wrote that Chinese learners "learn to read, write, speak and then comprehend aurally in exactly the reverse order stressed by Western pedagogy" (cited in Hu and Grove, 1991, p. 155). Others suggested Chinese students had different learning styles than non-Chinese language learners and that they preferred different teaching methods.

Secondly, writers claimed that Chinese methods of teaching were different from those of Western teachers and that they were methodologically unsound. Most criticisms came from Westerners who had taught in China for a short period of time. Criticism focused on the non-communicative methods of teaching, the emphasis on repetition and literature, and the text books used. These criticisms tended to be fairly condescending and subjective, and they provoked this investigation into the causes of disagreement. The following section summarizes the views aired about Chinese learners and teaching methods, and discusses the premises which underpin this study.

\section{Western language teachers in China}

Foreign language teachers have had a significant presence in China since the Opium wars of the mid 1800s. But it was China's 'open door' policy of the late 1970's - early 1980's, that precipitated the latest wave of Western English teachers entering China. Consequently foreign language teachers began to write articles about language teaching in China, particularly English language teaching. Most of these articles reflect the subjective experience of individual 
teachers and are critical of Chinese methodology. Some writers implied that China was behind the times because it had not adopted Western methods. Typically a writer criticized the methodology, materials, and language skills taught at the school he or she visited. For example, Griffith writes:

With time, the [Chinese] may adapt a little better to Western attitudes to pedagogy, but the learning habits of centuries are hard to undo. Role playing and free discussion are quite alien to Chinese students, especially when there is a 'political form monitor' sitting in on classes... If you try to initiate something new,... the Foreign Affairs Office in your institute may make enthusiastic noises but do nothing to help you... It is not easy to know when to prolong negotiation and when to admit defeat. (1991, p. 230)

Ye and $\mathrm{Li}$ provide a more moderate description:

More and more American English teachers are currently seeking ESL teaching positions in China. Upon arrival, however, they are often surprised to find that the available texts are quite traditional and quite different from modern texts used in the U.S., and that student expectations are also quite different. (1988, p. 59)

There have been varied reactions to these reports by Western teachers (see Lamoureux n. d.). Moffett (1983) argues that Chinese students believe that the purpose of language learning is communication and that they demonstrate this by practicing speaking with, and imitating native speakers (p. 16). He suggests that students are motivated to learn speaking skills because they want to improve their chance of going overseas.

A further criticism of language teaching in China is that traditional teaching methods are used because the teachers do not have a good grasp of the language being taught. This is not true of larger universities, where Moffett reports that "faculty speak with fluency, correctness, and are usually well grounded in the culture" (1983, p. 16), but applies to secondary schools, 
middle schools, and some smaller institutions. This situation is changing as many language teachers spend time abroad.

The above criticism may indicate the writer's beliefs about the role of the language teacher, rather than the failure of Chinese teachers. Dubin and Olshtain (1986) describe the changes that occur in language teaching when a change of method is made. The role of the teacher within the grammartranslation approach (which focuses on outlining grammar points and translation) is described below:

In the grammar-translation tradition, language teachers were thought of as people who knew the target language and its literature thoroughly, but did not necessarily speak the language fluently. The textbook contained all the necessary information about the language; the teacher's assignment was to be a faithful implementor by explaining its contents. (1986, pp. 47-8)

Dubin and Olshtain go on to say that for audiolingualism the role of the teacher is to be able to speak fluently and provide a model for the class by conducting oral drills with learners. Thus, as emphasis turned from grammar to performance, different expectations were placed on the teacher (p. 48). The criticism directed at Chinese language teachers is likewise colored by the methodology favored by the critics.

Young and Lee sent questionnaires to 532 Hong-Kong Chinese elementary and high school teachers of English which asked about their attitudes towards teaching methods. The results indicated that in general, teachers preferred methods favoring transmission (that is, teacher centered approaches) over other methods favoring interpretation (that is, student centered approaches) (1984, pp. 193-4). Western pedagogy, on the other hand, prefers teaching methods that focus on interpretation over transmission. 
Grabe and Mahon (1982), two Westerners who trained Chinese teachers of English, claim that the reason Chinese language teachers prefer 'transmission' approaches is they are challenged by recent western communicative approaches which demand flexibility and expose any language inadequacy:

Close analysis of familiar texts was something they could do over and over again with confidence, without stretching their English beyond their limits. Most trainees were, therefore, unwilling to innovate [and responded to new methods with] 'We can't use that in China. The students' won't like it, the senior faculty won't like it'. (1982, p. 55)

Grabe and Mahon conclude that Chinese teachers will not consider using new techniques or methods unless they have proven to themselves that the methods work and can see how to incorporate them into their own classrooms.

Practical limitations can also hinder the implementation of new methods. The size of language classes in China makes it difficult to implement many teaching strategies popular in smaller language classes abroad. Ye and Li report class sizes to be 30-100 (1988, p. 67), whereas in America, the average university language class has 15-30 students. Similarly, differing ideas about learning and teaching influence which methods are used. The communicative approach draws heavily on the use of learning games and activities, and thus violates the belief that learning is serious. In Chinese classrooms serious academic activities have priority over game-like activities.

Chinese teachers of English have responded to Western criticism and methods in varied ways. Ye and $\mathrm{Li}$ discuss some of the shortcomings of Chinese language instruction: "Classroom instructions do not seem to do as much as they should in developing the students' English skills...The students 
may know every word of a text, but fail to understand the main ideas" (1988, pp. 59-60). On the other hand, a Chinese teacher remarked that "Western language teaching methods aren't effective with Chinese students. Our traditional methods are good enough. Look at how well Gao learned to speak English. He's never been out of China and didn't have any contacts with native English speakers until this year. So our methods must work" (cited in Huang and Van Naerssen, 1987, p. 288).

Professor Pan of the Chinese Association for English Language Education remarked that the national attitude regarding language teaching methodologies is that 'whatever creates real competency is fine to use' (cited in Lieberman, 1984, p. 19). This said, China does not appear to have adopted Western methods on a large scale. Burnaby and Sun (1989) surveyed twentyfour Chinese teachers of English about the appropriateness and effectiveness of Western methods for use with Chinese students. Their general feeling was that Western methods were only applicable to students who wished to go to an English-speaking country to study. Teachers based their decisions on the purpose and learning contexts of their students, the national curriculum, class sizes, and the conviction that their students will learn the English skills they need through Chinese teaching methods: "the Chinese use their own methods not just because contextual constraints make it difficult for them to use communicative methods but also because it suits their students' purposes" (Burnaby and Sun, 1989, p. 227).

To summarize, Western methods of language teaching have not met with large scale enthusiasm by Chinese teachers. Chinese teachers recognize some shortcomings of their methods of teaching but state the incompatibility of Western methods with students and curriculum as reasons against 
methodological change. The following section discusses reasons for this lack of compatibility.

\section{Explanations for dissatisfaction}

Two explanations have been posed as to why Chinese language teachers are dissatisfied with Western methods and why Western teachers have been dissatisfied with Chinese methods: culture, and the learners.

Lado (1986), writing about cultural differences, asserts that most people are ethno-centric and judge the world around them by their own standards:

... the members of one culture usually assume that their way of doing things, of understanding the world around them, their forms and their meanings, are the correct ones. Hence when another culture uses other forms or other meanings it is wrong. Hence, when another culture adopts a pattern of behavior from the first one, the imitated culture

feels that something good and correct is taking place. (1986, p. 59)

Lado also suggests that any assumptions made regarding whether an action occurs or not are culturally determined (p. 60). The existence of communicative or text-based activities in a classroom will cause an observer to make culture-based assumptions and judgments about the observed teaching practices.

Saville-Troike (1978) claims that a society's educators are examples of successfully acculturated individuals, that is, people who have succeeded in that society. Writing for teachers with students of other cultural backgrounds, she claims:

[Teachers] are transmitters of ... attitudes, values and expectations to the next generation so that it too may 'achieve' in school. Educators must therefore learn about their own system of learning and realize that education does not have the same ends and means for members of different social groups. Stereotypes result if we assume that other systems of education are less advanced, or the students who don't 
succeed in our particular system are 'deficient' in some respect. (1978, p. 29)

Foreign teachers in China have trained and taught in non-Chinese education systems and may benefit from an understanding of the differences in expectation and action between the educational systems. Hai- $\mathrm{Li} \mathrm{Li}$ calls for mutual understanding between Chinese and foreign teachers in China:

It is absolutely essential for Chinese teachers of English and foreign teachers working in China to learn and understand each other's culture so that they will be able to provide their students with adequate social and cultural background knowledge and increase their ability to communicate. (1982, p. 92)

Young believes that not only teachers but also language teaching methodologies are culturally laden.

Claims of universality made by psychologically and linguistically inspired reforms tell us far more about the culture which gave birth to the... ideas than they do about the applicability of the ideas in educational settings outside North America or Western Europe. (1987, p. 17)

Young identifies research which indicates that children from different cultural groups exhibit different learning styles, and that teachers can use various teaching styles. Furthermore, where teacher and learner styles match, children's educational achievement increases. Young's indirect suggestion is for teachers of English to adapt their teaching styles to their students, as teachers are in a better position to be flexible than students, students need to learn a set of material, and each classroom contains students with a wide range of learning styles.

The second explanation as to why Chinese and Western teachers are dissatisfied with each other's teaching methods, relates to learning styles. Many teachers, both Chinese and Western, identify Chinese students' preferred learning styles as thwarting the implementation of Western 
methods in China. Underlying many people's viewpoints is the idea that Chinese students are a unique breed - somehow different from other language students. Maley (1986) posits that foreign language teachers and Chinese students have different views on the nature of the teaching process. Chinese students tend to view language-learning as memory based and comprising grammar, vocabulary and non-contextual processes rather than meaningful communication. This is frustrating to many foreign teachers, but foreign teachers' methods are equally frustrating to students.

Oxford (1990) poses that learning can occur via direct or indirect strategies. She recommends that teachers discover whether or not the learners' culture endorses a chosen learning strategy before suggesting that students use it. Oxford also recommends that the teacher choose strategies which do not contradict what the learner is already doing:

You need to be sensitive to learners' original strategy preferences and the motivation that propels these preferences... you might need to phase in new strategies gently.. without whisking away students' 'security blankets' no matter how dysfunctional you might consider those old strategies to be. (Oxford, 1990, p. 207)

Pia (1989) examined the preferred learning styles of 30 Chinese students studying English in China and 30 Chinese students studying English in America and compared them with 30 Americans studying Chinese with the intention of finding out whether a distinct Chinese learning style emerged. He could not distinguish a consistent group pattern, and suggested that a variety of styles and strategies be provided for students in the classroom. Pia's study raises the point that any teaching method may be appropriate in a given situation. Like Pia, Willing (cited in Nunan, 1989, p. 52) found that students' preferred learning styles and strategies did not group around ethnicity and age. Oxford, Hollaway and Horton-Murillo (1992) reflect that: 
Many style conflicts exist within a given culture as well as across cultures. Culture is thus not the only factor that plays a role in style development and style clashes; people are indeed individuals with their own traits. However, valid generalizations about learning style can be made concerning different cultures and ethnic groups as a whole. (p. 451)

Thus while the issue of 'learning styles' provides sound suggestions for teaching, learning styles do not identify the cause of conflict across ethnic groups, or provide us with something that is unique to a specific ethnic group, such as Chinese students. Similarly culture gives us an idea of what is 'expected' or 'normal' in a society but does not clarify what may or may not be effective for use in that society.

This study examines whether the use of Western methods in China has incurred difficulties due to any incompatibility between the foreign curricula $^{2}$ and the Chinese setting, educational goals and beliefs about learning. Dubin and Olshtain's (1986) curriculum framework which outlines the links between a language curriculum and the society that it operates in, is employed to examine the language setting in China. This framework is summarized in Figure 1, an adaptation of their diagrams (pp. $6 \& 43$ ).

Dubin and Olshtain's framework describes three layers of influence on a language curriculum. The first layer comprises four interrelated parts: (i) the language setting: attitudes about and use of the target language; (ii) patterns of language use in society: the role of the target language in education, the labor market and the modernization process; (iii) group and individual attitudes

2 Curriculum is used here to refer to the broad goals and policies from which specific syllabi (detailed course outlines) can be written. 

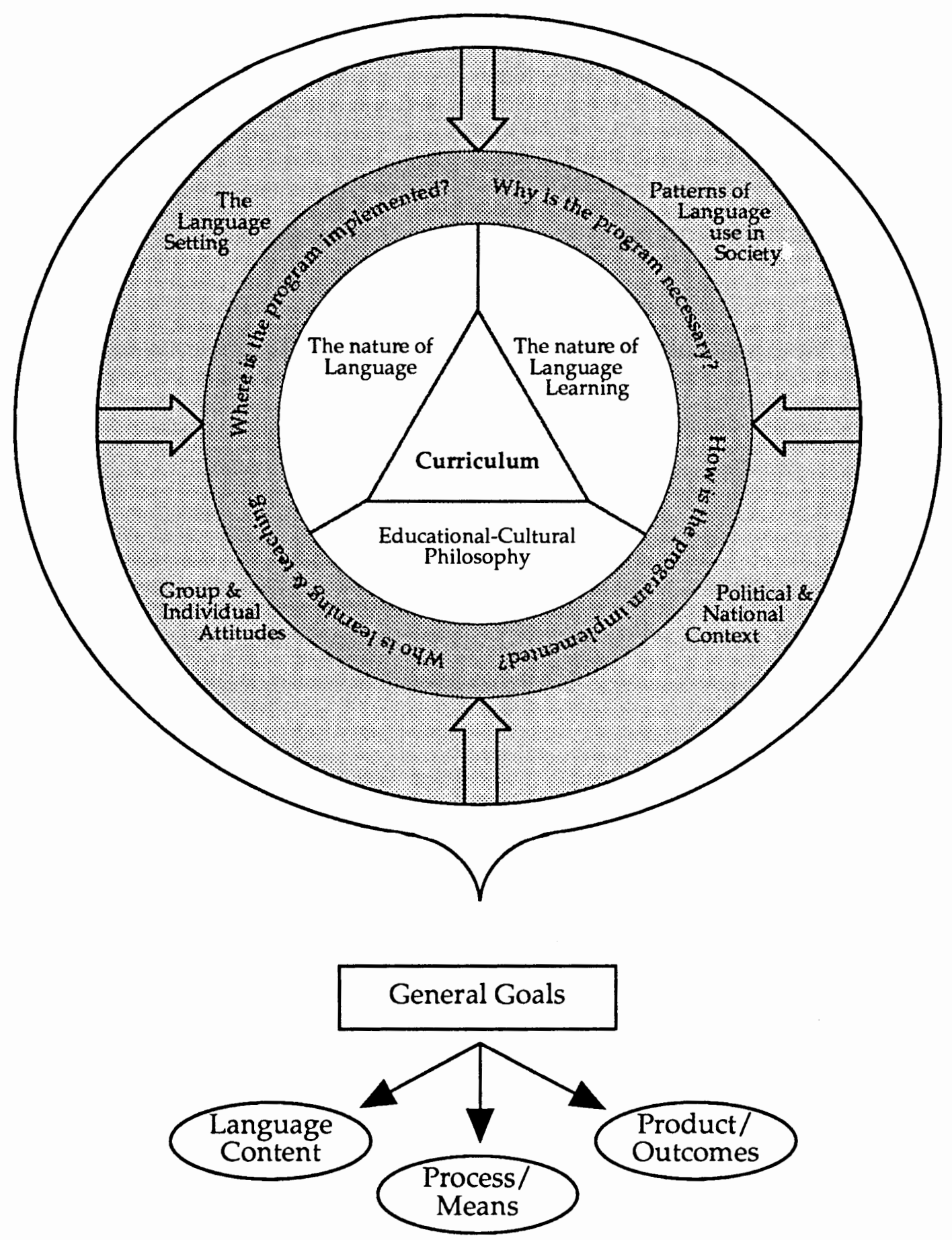

Figure 1. Factors influencing curriculum. Adapted from Dubin and Olshtain (1986, pp. 6 and 43). 
about the process of language learning and the target language; and (iv) the political and national context in which language learning occurs.

Dubin and Olshtain's second layer of curriculum design looks at the role of educational-cultural and language goals on curricula. They suggest that views about language, language-learning and education-culture are interwoven. As an example, they suggest that "the behavioristic view is an educational-psychological philosophy which is compatible with a structuralist view of language and a stimulus-response view about human language learning" (p. 35).

The third layer of Dubin and Olshtain's model suggests that general goals stem from the above layers, and result in syllabus objectives regarding language content: what material is covered; process: how the material is learned; and product: what students should be able to do at the end.

The focus of the discussion regarding English language teaching in China seems to have been the third layer of Dubin and Olshtain's framework: that is, the content, process and product of the curriculum. However, Dubin and Olshtain's framework indicates that the underlying cause of friction lies in the first two layers, that is, national expectations about education, language learning, and the functions of language in society. It would appear that the social, cultural, educational, and language viewpoints embedded in Chinese curricula are different from those of many Western countries.

Johnson's language curriculum framework (1989) outlines four levels of curriculum development with the people and products involved in each stage, see Table I (Johnson, 1989, p.3). His framework focuses on three sets of constraints: policy, pragmatics, and participants. It is his discussion of policy (statement of aims) that is most relevant here. Policy decision making, 
according to Johnson, involves the sequence of curriculum planning (the definition of aims based on needs analyses); ends/means specification (providing objectives in terms of accountability or communicative competence, and methodology); program implementation (developing materials and training teachers); and classroom implementation (teacher and learner acts).

\section{TABLE I}

STAGES, DECISION-MAKING ROLES AND PRODUCTS IN CURRICULUM DEVELOPMENT

\begin{tabular}{|c|c|c|c|}
\hline \multicolumn{2}{|c|}{ Development stages: } & Decision-making roles: & Products: \\
\hline \multicolumn{2}{|c|}{ 1. Curriculum planning } & policy makers & policy documents \\
\hline \multirow[t]{2}{*}{ 2. Specification: } & ends & needs analysis & syllabus \\
\hline & -means & methodologists & \\
\hline \multirow{2}{*}{\multicolumn{2}{|c|}{ 3. program implementation }} & materials writers & teaching materials \\
\hline & & teacher trainers & teacher-training program \\
\hline \multirow{2}{*}{\multicolumn{2}{|c|}{ 4. Classroom implementation }} & teacher & teaching acts \\
\hline & & learner & learning acts \\
\hline
\end{tabular}

Source: Johnson, 1989, p. 3.

Johnson points out that where the four levels do not match, where they do not work towards the same ends, then the effectiveness or applicability of the curriculum diminishes. An example given by Johnson is where teacher trainers act not as a bridge between the syllabus and the classroom, but against the curriculum as methodologists:

Theoretical teacher trainers tend to be specialists in applied linguistics in general and methodology in particular. Their knowledge of the curriculum they supposedly serve is often limited, their attitude towards it may often be dismissive and their efforts directed towards 
revolutionising rather than implementing it... They often have little sympathy with official policy and would like it changed, usually in a direction better suited to their favourite 'method'... However justified their criticisms, these teacher trainers gain little credibility and have little influence, least of all with teachers. (Johnson, 1989, p. 9)

Where teachers or teacher trainers are 'brought in' from outside, as is often the case in the teaching of English as a foreign language, mismatches such as the above are to be expected. In the case of China, problems seem to occur when teachers and teacher-trainers aim to influence areas of the curriculum other than those assigned to them by their job-description.

The frameworks outlined by Dubin and Olshtain (1986) and Johnson (1989) help to identify potential underlying sources of educational differences between China and Western countries. Their frameworks provide a basis on which to question the universal applicability of both a curriculum and components of a curriculum. Variation in setting, goals, and language and educational-cultural viewpoints of the society are variables that are specified as potential causes of the failure of a curriculum.

With regard to the debate over teaching methods in China, Dubin and Olshtain's framework suggests that the educational cultural and language viewpoints of the foreign language teachers and those of the Chinese teachers of English are potentially 'mismatched'. Johnson outlines those areas that may provoke conflict about decision making roles. Thus by discovering the views about language, language learning and education plus the educational structure prevalent in China, areas of conflict with their Western counterparts can be identified, and the compatibility and (potential) effectiveness of Chinese and Western curricula and methods for use in China can be gauged. 
This study sets out to elucidate the critical components of Dubin and Olshtain's framework, and thereby provides evidence to support a more definitive approach to teaching English in China. The investigation follows the set of research questions given below.

\section{RESEARCH QUESTIONS}

1a. What are the views about language prevalent in China among English language learners and teachers in Chinese universities?

1b. Do the prevalent views about language lend themselves to the use of a particular methodology? If so, what methodology?

2a. What are the views about language learning prevalent in China among English language learners and teachers in Chinese universities?

$2 \mathrm{~b}$. Do the prevalent views about language learning lend themselves to the use of a particular methodology? If so, what methodology?

3a. What are the views about education prevalent in China among English language learners and teachers in Chinese universities?

$3 \mathrm{~b}$. Do the prevalent views about education lend themselves to the use of a particular methodology? If so, what methodology?

4a. What is English needed for in China?

4b. How does this affect the way English is taught, the methodology and curricula?

5. Is the communicative approach appropriate to the curriculum and use of English in China? If not, could it be adapted? The Communicative 
Approach was chosen here because it is currently the most wide-spread method used to teach English in 'Western' countries and has attracted a lot of controversy in this discussion.

6. How do the methodologies identified in $1 b, 2 b, 3 b$, and $4 b$ contrast with the methodologies prevalent in the United States of America? 


\section{CHAPTER II}

\section{LITERATURE REVIEW}

\section{INTRODUCTION}

Education in the People's Republic of China, including the teaching of foreign languages, has been closely linked to the political structure of the country. An awareness of Chinese history assists understanding of trends in education and the perspectives of the Chinese people. In this chapter a brief history of China will be followed by an examination of education, and of foreign language teaching in China. Each section will include a discussion of influential social values.

\section{AN OVERVIEW OF THE HISTORY OF CHINA}

\section{China before 1911}

The nation of China dates back before 2000 B.C.. The earliest recorded history is largely mythical. From c. 2000 B.C. up until 206 B.C., China was ruled by several kingdoms. From 206 B.C. until 1911, six major dynasties were established then dissolved, with periods of warfare and division towards the end of most dynasties. Table II summarizes the social characteristics of these periods. A general feature of all the governments was that a small, usually educated class ruled the largely agricultural society. Watson (1966), D. J. Li 
TABLE II

A SUMMARY OF CHINESE HISTORY BEFORE 1911

\begin{tabular}{|c|c|c|c|}
\hline Time period & Rule & Social characteristics of the period & Other features \\
\hline c. $2000-1500 \mathrm{BC}$ & Hsia kingdom & Unknown & \\
\hline c. $1500-1027 \mathrm{BC}$ & Shang kingdom & Agricultural, peasant-run society & $\begin{array}{l}\text { Bronze discovered, shell-bone script } \\
\text { used extensively }\end{array}$ \\
\hline $1027-221 \mathrm{BC}$ & Zhou kingdom & $\begin{array}{l}\text { Feudal society, military conflict ( } 800 \text { B.C. } \\
\text { ff.) }\end{array}$ & $\begin{array}{l}\text { Dvpt of schools of philosophy } \\
\text { including Confucian, Mohist, Daoist } \\
\text { \& Legalist }\end{array}$ \\
\hline $221-206 \mathrm{BC}$ & Qin kingdom & $\begin{array}{l}\text { Legalistic government despised literature } \\
\text { \& philosophy. }\end{array}$ & $\begin{array}{l}\text { Destruction of books to suppress the } \\
\text { literary class. }\end{array}$ \\
\hline $206 \mathrm{BC}-221 \mathrm{AD}$ & Han dynasty & $\begin{array}{l}\text { Civil service of educated men, largely } \\
\text { nobility. Landlord/tenant system. } \\
\text { Confucianism established }\end{array}$ & Empire expanded \\
\hline $316-589 \mathrm{AD}$ & $\begin{array}{l}\text { Northern and } \\
\text { Southern dynasties }\end{array}$ & Buddhism spread & $\begin{array}{l}\text { Literature \& the arts flourished. } \\
\text { Division amongst warring kingdoms }\end{array}$ \\
\hline $618-906 \mathrm{AD}$ & Tang dynasty & $\begin{array}{l}\text { Bureaucracy recruited by public exams } \\
\text { gradually replaced aristocratic upper } \\
\text { class }\end{array}$ & $\begin{array}{l}\text { Census recorded entire population as } \\
52,880,488 \text {. }\end{array}$ \\
\hline $960-1279$ & Song dynasty & $\begin{array}{l}\text { Civil service continued. Confucianism } \\
\text { influential }\end{array}$ & Painting famous. Empire lost territory \\
\hline $1280-1368$ & Mongol rule & Harsh rule & \\
\hline $1368-1628$ & Ming dynasty & $\begin{array}{l}\text { Civil service re-established. Internal } \\
\text { unrest }\end{array}$ & \\
\hline $1644-1912$ & Qing dynasty & $\begin{array}{l}\text { Manchurian rulers considered alien by the } \\
\text { rest of China }\end{array}$ & $\begin{array}{l}\text { Slow internal collapse due to internal } \\
\text { dissatisfaction \& external pressure }\end{array}$ \\
\hline
\end{tabular}

NOTE: Between most of the dynasties and kingdoms there were periods of war. 
(1978), Fitzgerald (1992) and Spence (1986) provide interesting accounts of these periods.

The collapse of the dynasty system in 1911 was largely due to internal dissatisfaction, modernization, and contact with the West. The rural farming population had difficult lives in every dynasty. During the Qing dynasty, gradual overpopulation and the deteriorating governmental infrastructure added to the dissatisfaction of the people. In addition, the Manchurian Qing dynasty was perceived to be foreign by most of China. Three large scale rebellions occurred during the Qing dynasty: the Taiping rebellion (1853-64) in central and SE China, a Muslim rebellion in NW and SW China, and a peasant led rebellion in NE China. A second reason for the collapse of the dynasty was the external pressure from Western countries desiring trade. Initially China resisted. However the Opium wars of 1839-1842 and 1856-1860 forced China to open cities and trade goods for opium.

\section{China 1911-1949}

Prior to 1911, China had typically experienced periods of peace under an established ruler followed by upheaval until a new ruler was established. Between 1911 and 1949, China experienced rapid change and a series of governments, but little peace. Since 1949, there has been constant social reform and upheaval. The fabric of Chinese society has been unraveled and repeatedly rewoven.

By the conclusion of the Qing dynasty, China's intellectuals were actively searching for a new form of government. In 1911 anti-Qing republicanism was widespread and Sun Yat-sen, a revolutionary from Guangzhou, advocated the formation of a republic and infiltrated the army 
with his supporters. Simultaneously, the Qing dynasty called on the ruler of the imperial forces, Yuan Shikai, to help them restore their dynasty. Yuan double-crossed them and made an agreement with the republicans which stated that he would ensure the end of the dynasty, and then rule until elections could be held. In 1908, the Guangxu emperor and the empress Dowager Cixi died. The last emperor was the Xuantong Emperor, Puyi, who ruled from 1908 until the outbreak of revolution in 1911. Democratic elections were held in 1914, but the temporary president, Yuan, exiled Sun Yat-sen and the winning party (Spence, p. 104) before attempting to establish a new dynasty with himself as emperor. Yuan's death in 1916 led to a period of struggle for control of China by Yuan's subordinates and others; this was known as the war-lord era (1917-1927) (Fitzgerald, p. 186).

Sun Yat-sen returned from exile and, with the assistance of the USSR, established the communist party. However, his death in 1925 removed any hope of a peaceful settlement between the competitors for power (Fitzgerald, pp. 186-7). The nationalist party (Guomindang) led by Chiang Kai-shek, gained support and after setting up a government in Hunan, began to 'exterminate' communists (1929-1935). Thus, the 100,000 strong communist party began in 1935 its year long march to north China to escape Chiang. It arrived with 30,000 men. The Japanese invasion (1937) diverted Chiang's attention from the civil war by forcing Chinese forces back to Western China. But when Japan retreated in 1945, civil war quickly resumed. Internal social and economic problems, combined with harsh treatment kept the largely peasant population opposed to the current leaders (Guomindang). The freedoms put in place by Sun Yat-sen had little impact on the masses. Mao appealed more to them as he spoke their language and relied on known 
tested methods to solve problems. When the communist party began to win the civil war, the Guomindang reacted impulsively. They "seemed to have gone completely crazy when they realized the end had come... [they] were on a mad looting, killing and burning rampage" (Burchett and Alley, 1976, p. 78). The establishment of the People's Republic of China thus restored some order to the disquieted nation.

\section{China 1949-1970s}

The People's Republic, after an initial period of consolidation (1949-52), launched into the first five year plan (1953-57) investing in industry, borrowing educational techniques from Russia, (Paine, 1986b, p. 110), and redistributing land according to family size: a popular move (Cogan, 1986, p. 113). The Korean War (1950-1953) gave the new communist government the opportunity to demonstrate that, for the first time in a century, China was able to stand up to foreign powers (Fitzgerald, 1992, p. 188).

1958-59 brought the Great Leap Forward. Agriculture was organized by communes, industry was decentralized and education was rapidly expanded (Paine, 1986b, pp. 110-111). However, many of these policies did not work and so were reversed in 1960-65. As China moved further from Soviet ideology, Sino -Soviet relations worsened to the point that Russia withdrew technical experts in 1960. During the early 1960s, Mao appeared to have taken a back seat in leadership, but in 1966, he masterminded the Cultural Revolution as a display of his control. The Cultural Revolution (1966-1976) was "aimed particularly at culture, ideology and education, [and] challenged previous policies as bourgeois and revisionist" (Paine, 1986b, p. 111). At this time, Mao asked young people to form a 'red guard' and take measures against any 
counter-revolutionaries. The following quotation from his investigation of the peasant movement in Hunan, was transformed into a song which inspired the young radicals:

Revolution is not like giving a party, Composing a piece of literature, or Making fine embroidery.

It is not refined, leisurely, or polite;

It is not gentle, modest, or respectful.

Revolution is violence;

It is the overthrow of one class by another--

By violent action! (Mao, 1966, pp. 11-12)

Mao inspired young radicals to the point that the eruption of a civil war was only prevented by a recorded message from Mao that instructed youth to stop fighting, and the decision to send educated youth and the Red Guards to the countryside (1966) to serve the people by working on farms ( $\mathrm{Li}, \mathrm{p} .558$ ).

\section{China 1970s to the present}

After the death of Mao (1976) and the arrest of the gang of four (1976), the cult of Mao weakened and the government led by Hua Guoteng brought in the Four Modernizations (1977). The Four Modernizations targeted national defense, science and technology, industry, and agriculture as areas of development (Grabe \& Mahon, 1982, p. 50). The government acknowledged that it had made errors during the Cultural Revolution but did not incriminate Mao. The open door policy of 1978 and greater industrialization and trading indicate that China continues to change rapidly even through comparative political stability. However, unrest continues to surface (1986, 1989). It may pay to remember that Mao himself said that after 1949, China was in a struggle between communism and capitalism. He commented that 
"change is always present in a society and change is never smooth " (cited in Paine, 1986a, pp. 108-9).

\section{Values held in Chinese society}

The values held by the Chinese people influence the way Chinese society operates. Several of these values are loyalty to group, respect for authority, and the concept of one's 'face'.

The collective group in China has been regarded, in many respects and by many people, as more important than the individual from before the birth of Confucius (551 BC); as such the group often constrains the individual.

To the Chinese mind, the collective welfare of a group had priority over the well-being of the individuals who composed it, and the enhancement of group welfare would presumably enhance individual well-being as well. Theoretically at least, human relations were more important than human beings. Such emphasis tended to degrade individuals rather than elevate them, because it made them mere points of conjunction in the intricate pattern of human relations. $(\mathrm{Li}$, 1978, p. 68)

The importance of the collective has surfaced as individual selflessness, as pursuit of an ideal for the common good, and as observance of promises, which are expected to be observed at all cost (D. J. Li, p. 70). On the other hand, Chinese society can be highly individualistic to the extent that some groups do not function particularly well.

A definite social order exists in Chinese society. Within the family, children are taught to respect their elders. At the societal level, the educated civil service were the authority that was paid tribute by the uneducated peasants. Ironically the communist 'people-run' government has replaced the old system with a new group of authorities: members of the communist 
party. Those with high party positions are placed superior to others and granted social privileges.

\section{EDUCATION IN CHINA}

Chinese education has reflected the dramatic events that have changed the nation. Formal education has existed in China for thousands of years with schools operating since the Han dynasty (Benson, 1988, p. 12). Of the Ch'in dynasty, D. J. Li writes

The importance of education did not mean that everybody could have an education. For the most part, the privilege of enjoying it was confined to a small group. Though he was not legally restricted from obtaining an education an average peasant was simply too busy tilling his field and trying to make ends meet to be seriously concerned with it... The gentry scholar [shih]... owned enough land or other support to spare them the necessity of doing physical labor. Second they had an education which provided them with the ways and means of acquiring leadership. (1978, p. 65)

Peasants revered the written word: "it was something obviously useful but incomprehensible to him" (D. J. Li, 1978, p. 554). Education consisted largely of the study and memorization of texts, many of which were Confucian. The implementation of the ideology contained in the texts (humility, morality, righteousness, and behaving according to social norms) was regarded as very important (see D. J. Li, 1978, p. 79), but was probably not included in the state examinations.

While changes have occurred over the course of time, three features were retained to the early twentieth century: (i) the centrality of the writings of philosophers, especially Confucius; (ii), the focus on reading and writing characters; and (iii), the limitation of education, and thus social standing, to nobility or the wealthy members of society. The Confucian ideal was for pure 
knowledge to be passed on as a collected canonized body of literature (Fox, 1989, p. 29). Teachers, as the conveyors of knowledge, were viewed positively. The teacher's role was to 'jiaoshu yuren' which literally means 'teach book, nurture people' (Hu and Grove, 1991, p. 77). Teachers were responsible for their students' social as well as educational development. In turn, teachers were treated with respect. The title 'laoshi' (teacher) includes the character 'lao': a prefix used to give respect to elders or those of higher status than oneself (Hu and Grove, pp. 17-18). However, the last dynasty, the Qing, during their last years of reign "abolished in 1905 the three-tiered state examination system based on the Confucian classics, which had dominated so much of Chinese intellectual and bureaucratic life for a thousand years" (Spence, 1986, p. 104). This dramatic decision which changed the focus of education, was but one of many changes to be made in education over the next decades.

In 1912, Chinese educationalists studied three external education systems to 'replace' the traditional system: the European, American and missionary school models of education (Fox, 1989, pp. 29-30). The European model of education was most similar to Chinese education, based around a centralized power, and emphasizing pure knowledge passed on through literature (Fox, p. 29). The American system had structural diversity and encouraged the 'rounding' of the individual (Fox, p. 30). The missionary school system was open to both men and women, and was by and large the first contact that many Chinese people had with English (Fox, p. 30). However none of these were adopted, and education remained fairly exclusive until 1943 when most primary schools were turned over to the people to be run by them and prevent reliance on bureaucracy. 
Establishing [people-run schools] obviated the need for taxation for education by the central government, and since taxation had been the bane of the peasants' existence, it made sense... to circumvent such methods of funding wherever possible. (Robinson, 1986, pp. 75-77)

Now that education was made available to the general public, they quickly dominated classes. Thus began the distinction between government and people-run schools: the two track system.

The communist revolution of 1949 further challenged traditional assumptions about education. The goal of education became universal elementary education rather than selective advanced education. Education aimed to raise general standards of literacy, numeracy, knowledge, skills and prosperity. Mao Zedong forecast that illiteracy would be wiped out by 1963. Traditional methods of teaching were used to achieve this: classes were large and few resources, including teachers, were available to achieve this enormous task. To achieve this, the government moved to regain control of schools. As government schools re-opened, people-run schools closed. In a further move to regain control, people-run schools were informed that unless national guidelines were followed, they could not be accredited. Most people-run schools could not achieve this and were not accredited. As a result, parents refused to allow their children to go to people-run schools, preferring them to stay at home to work in the fields (Robinson, 1986, p. 77).

In 1953 educational structure, texts and curricula were borrowed from the USSR (Paine, 1986b, p. 110). Following Russian methods, the government encouraged the pre-existent two-tracked school system to achieve the goal of educating the masses. However, the government did not help people-run schools. The lack of support given to people-run schools led not to flexibility in the classroom, but to an increased amount of political education. "Party 
cadres were appointed as principals of local schools, and [Communist Party] members were given a strong voice in decisions about school tuition, texts, and rules" (Robinson, p. 78). Peasants continued to criticize people-run schools as they wanted their children to gain status by receiving diplomas. In 1959 the Minister of Education criticized people-run schools as below standard and enforced greater controls over the schools. However, without any resources for improvement, people-run schools merely worsened and gained a poor reputation (Robinson, p. 80). Key schools were developed in 1959 by the Minister of Education in an attempt to improve the quality of education.

Ironically while this period stressed educational growth, teachers were persecuted. To be a teacher or 'learned' became a symbol of the past hierarchical system, and thus of unfaithfulness to the current political system. This attitude led to the year of the '100 flowers' campaign (1956), whose aftermath brought a time of educational change, such that 'rightists,' including many teachers, were shot or reformed. (Freeberne, 1992, p. 184)

The years 1962-1965 were a short period of educational revival. The quality of education was improved and research was encouraged. The Cultural Revolution of 1966 quickly undid this progress. Education was again decentralized, people-run schools were encouraged, and key schools were criticized as "'little treasure pagodas' that created a two-track system, and imputed inferiority to students and teachers in people-managed schools, encouraged self interest, and fostered antagonism to hard work among the people" (Robinson, pp. 81-82). During the Cultural Revolution, the bourgeoisie were humiliated; "The intellectuals, scholars, teachers, scientists, and academic people were considered the lowest on the list of undesirable 
elements in society: the 'stinking' ninth level" (Messerschmitt, 1986, p. 2). Moffett writes:

As a result of the destructive influence of the Gang of Four during this period [1966-1976], young people were turned radically against education, became activist Red Guards, and stopped studying. All Chinese universities were closed down, and the students and teachers were sent to the country for 're-education.' Teachers in general, and foreign language teachers in particular, suspected of being tainted by the wicked ways of the West, became special targets of the young revolutionaries. (1983, p. 13)

Teachers were subjected to humiliations such as written self-criticism, and theatrical trials. They were also assigned labor intensive or demeaning tasks such as cleaning toilets and vegetable storage cellars (Moffett, p. 13). Some committed suicide. When schools re-opened, they were taught by political heroes and peasants: thus politics dominated the curriculum. Finally Mao's death (1976) and the overthrow of the Gang of Four (1976) began lasting changes and the rebirth of positive attitudes towards education. Although many tertiary teachers retained the respect of the people, it has taken time to re-establish a favorable situation for other teachers in China.

The Four Modernizations brought a new period of growth for education in China. The new goals for education were (i) to improve quality, (ii) to create revolutionary order and discipline, (iii) to keep pace with requirements for development and (iv) to train teachers (Fox, 1989). Teachers were brought back into schools and exams were reinstated (Grabe and Mahon, 1982). Lack of funds meant that the ideal of complete centralization of education could not be achieved; thus people-run schools continued to operate (Robinson, 1986). Peasants were extremely dissatisfied with this situation, and expressed their antagonism by beating teachers who failed to get students through national exams, and forcing teachers to work on their 
farms in addition to teaching (Robinson, 1986). Teachers at people-run schools were also criticized by the government as being under-educated (Robinson, p. 86). It is no wonder that many of those assigned to be teachers are disappointed (Benson, 1988) despite government action to improve teachers' conditions.

The National Conference on Education held in May 1985 encouraged the development of primary level education. The Ministry of Education was abolished and replaced by the State Education Commission whose role was to formulate 'guiding principles of education', coordinate, standardize and regulate education throughout China (Savada and Dolan, 1988, p. 157). The conference established the goal of nine compulsory years of education. This was made law in 1986 and divided China into three areas. Highly developed areas were to enforce nine years of compulsory education by 1985. Moderately developed areas were to enforce the law by 1990 and underdeveloped areas were at some time to 'popularize' education. Again rural areas did not get equal attention (Savada and Dolan, p. 158).

After the Cultural Revolution, there was a push to improve the conditions of universities. One major goal was to improve university personnel (Cao, 1991, p. 103). This proved difficult as the Cultural Revolution had prevented a decade of potential lecturers and students from being trained. After the revolution, when the government was eager to encourage the growth of universities, there were not enough trained lecturers to fill vacant positions. Hence universities were forced to hire recent graduates in order to comply with the government's desire to expand (Cao, p. 105-7). In order to raise the standard of lecturers, in 1980 the Ministry of Education sent teachers to leading universities to receive further training. In 1984 the government 
required all university lecturers to have received postgraduate training. Many universities responded by holding in-service training for their staff and granting them diplomas (Cao, p. 107). Moffett writes:

Schools found themselves faced not only with the task of training new teachers and upgrading the competency of the poorly prepared ones, but also of influencing pre-cultural revolution teachers to break with old traditions and to substitute modern techniques for their antiquated pedagogy - this was perhaps the most formidable task. (1983, p. 14)

More recently, exchanges with other countries have seen 1500 foreign teachers work in China annually and given 60,000 Chinese teachers the opportunity to spend time abroad. The two problems that have come from this are the tendency of Chinese teachers, professionals, and students to remain abroad (Of 200,000 that went abroad, only 70,000 had returned by late 1993 according to Englesberg, 1994, p. 4), or to bring back Western ideas that are undesirable, namely 'western bourgeois liberalization' (Cao, 1991, pp. 110112). One reason that Chinese faculty stay abroad is that lecturers receive a comparatively low salary in China. Englesberg (1994) lists three ways that the Chinese government has acted to 'curb the brain drain': (i) liberal entry/exit rules, (ii) increased funding for research, (iii) providing opportunities for short term visits to foreign countries (p. 4). So far, these have not seemed to persuade the majority.

In addition, university conditions were improved after the cultural revolution by the adoption of a different view of knowledge.

Knowledge was no longer seen as an authoritative set of dogmas dictated from above in the form of national teaching plans that had a 'law like' authority, but rather as contingent and changing, something which the universities themselves were involved in creating and revising. (Hayhoe, 1993, p. 302) 
This change had enormous implications for universities. "China has a long tradition of maintaining social order through the regimentation of knowledge" (Hayhoe, p. 291). Thus, by viewing knowledge as dynamic rather than static, the authorities gave to educators a degree of control over what could and indeed should be taught. In the 1980s universities were given a mandate to carry out research with the intention of updating curricula (Hayhoe, p. 302). Relaxed political control saw the development of the social sciences and humanities. However, this academic and intellectual freedom led to dissatisfaction with the status quo and eventually to the student demonstrations of 1986 and 1989 (Hayhoe, p. 292).

Student demonstrations have occurred in China since the turn of the century. On May 4 1919, students protested the government 'sale' of the port of Qingdao to Japan, in resistance to foreign control (Fitzgerald, 1992, p. 186). Students were the predominant participants of the Cultural Revolution. In 1986 and 1989, students demonstrated in Tian'anmen Square with the intention of bringing about pro-democracy discussions with the government.

The government's response to Tian'anmen Square has brought the most recent changes to education in China. Three areas of change have been identified by Hayhoe: enrollment, curricular reform, and research. Post Tian'anmen Square, the government restricted the number of students permitted to enroll in each university, especially those universities that had been central to student uprisings. The number of humanities students has declined dramatically (Hayhoe, p. 294). Secondly, while faculty are expected to respond to and accommodate the need for new knowledge, party secretaries have been appointed "to initiate and oversee a thorough expunging of all tendencies towards 'bourgeois liberalization' which were seen as responsible 
for the student movement" (Hayhoe, p. 297). Humanities teachers have had to review each of their programs and student theses to look for clues to the Tian'anmen uprisings (Hayhoe, p. 297). The faculty is seen as "responsible for the political orientation of their students" (Hayhoe, p. 298). Science faculty continue to be encouraged to research and develop while research in the social sciences and humanities is reviewed and controlled for 'political correctness' leading to superficial studies (Hayhoe, p. 305-6). Cao writes that "many university staff felt lost when the political battle was over [in 1989] because it is widely accepted in society that western bourgeois liberalization has had a greater influence upon academics' ideology in the past ten years " (1991, p. 114).

Rosen (1993) outlines a fourth measure taken by the government since Tian'anmen Square: re-education of new students. First year students at two major universities, most strategically Beijing University, have been targeted for a full year of military training and re-education. Other universities have had to install programs of a minimum of three weeks (Rosen, 1993, pp. 318320). This was done "in an attempt to forestall a recurrence of the turbulence and, more ambitiously, win back the hearts and minds of Chinese youth" (Rosen, 1993, p. 310). However, the goal has been far from accomplished and many re-educated students have faced humiliation from peers upon their return. Rosen suggests that the two factors which have maintained peace are firstly the greater control of job placement assumed by the government:

The evidence presented in this study suggests that the programs designed to re-educate and instill regime-sponsored values among Chinese youth have not and will not succeed... Where the Chinese government has been effective, however, is in controlling actual behavior. This has not been accomplished through normative appeals to be patriotic or accept socialism as the only road for China, but by 
rather cruder measures such as controlling job assignments and deciding which university graduates will be allowed to remain in Beijing. (Rosen, 1993, p. 331)

and secondly by adding financial incentive: "By encouraging intellectuals to concentrate on making money, the regime has purchased some breathing room" (Rosen, p. 332). Surveys carried out recently in China have found that students, both secondary and tertiary, do not take government authorities seriously any longer. Rosen believes it is likely that more university demonstrations will occur as, while on the surface there is stability, "underneath there are deep layers of ideological problems which have not yet been solved" (Rosen, 1993, pp. 333-334).

Finally, the economic advancement of an 'upper class' in China has brought about a new development in Chinese education: private schools. The first private boarding school opened in 1992: Guang Ya Private Primary School in Sichuan province. The initial enrollment fee is US $\$ 7000$ with a yearly tuition fee of US $\$ 1200$. The students board, English learning is pushed and each classroom has a TV, computer, air conditioning, and good lighting. Parents proudly bear the huge expense in the hope that their children will be more adequately prepared to face China's economic development (Barkley, 1994, pp. 13-14).

Chinese education post 1949 could be generalized as a focus on "technical training at the expense of intellectual pursuit for its own sake" (D. J. Li, 1978, p. 556). The People's Republic of China Yearbook 1988-1989 summarizes the educational situation in China as follows:

China has made remarkable success in controlling the population but has not yet made satisfactory progress theoretically or practically, in improving its quality... Elementary education is weak... Higher 
education is relatively backward... Adult education needs further

development... Educational funds are inadequate. (1988, pp. 511-512)

While the above is a pretty grim summary of education in China over the last century, there have been many ways in which education has improved dramatically: for one, education is no longer restricted to the financially and socially elite; literacy in 1988 stood at $83.5 \%$ for males, and $61.25 \%$ for women (The New Book of World Rankings, 1991, pp. 242-245) which is no small feat for a country of over 1.1 billion; and finally, the rapid development of scientific and technical fields has been commendable.

\section{Views about education in China}

Education in China was for many years the vehicle for social mobility but was available largely to the elite. The positive view of education comes through in ancient texts such as the three character classics: "Man is by nature good but dependent on his education. Otherwise he remains the stone that is uncut--just as a piece of stone lying at the bottom of the waste is not a gem." (cited in Burchett and Alley, 1976, p. 53). Literacy and education have long been linked with social change. Hayhoe states that currently education is viewed as 'basic engineering' for socialist modernization (1993, p. 295-296), that is, as a tool to improve society. There is still competition for higher education in China, with only $2-3 \%$ of high school graduates passing the national examination that qualifies them for tertiary education.

Teachers in China are expected to be the professional superiors of their students and are obliged to set a good example. Usually students would support their teachers ideologically as well as socially and would express disagreement only in some university classes. The current lack of respect given to teachers in rural districts (see Robinson, 1986, p. 84 ff.) is largely a 
result of the perceived failure of the teacher to meet this standard: many teachers in rural districts have not been trained 'adequately' according to national standards, and thus are not professionally superior. Rosen discusses surveys which provide evidence that students no longer rely on their teachers. These surveys have indicated that high school students in China now "rely almost exclusively on friends and classmates for knowledge and support, while ignoring classroom teachers and political councilors" (1993, p. 333).

Another manifestation of the concept of the teacher as superior is the tendency for class activities to focus on the teacher. Ye and $\mathrm{Li}$ (1988) note that "although changing to some extent, the traditional teaching approach still retains two important features: teacher-centeredness and knowledgeorientation" (p. 63). Most classes retain two features of traditional lecture style: they follow an outline of several points (Fox, 1989, p. 121), and carefully analyze texts (Grabe and Mahon, 1982, p. 51). The large classes of 30-100 students encourage this format.

Wang (1988) states that "Chinese students are uncomfortable with humanistic approaches suggested by modern methodologists, and prefer a teacher centered approach" (p. 28). Wang (1993) describes interviews with several Chinese students studying in America. One compared the educational systems of China and the U.S.A.:

The difference in educational philosophy between the two countries is often a barrier to my adjustment to the academic life here. In China, education is centralized and we have a nationalized curriculum implemented by all schools across the country. The teacher is considered the authority and students are always listening. In the United States, education is decentralized and there are no guidelines for everybody to follow. Different ideas are tolerated in class. (Wang, 1993, p. 108) 
After reviewing a body of literature on Chinese learners, Young (1987) concludes that there are patterns of teaching and learning distinct to Chinese. He suggests that these are that Chinese children pay more attention to the teacher than to their peers, Chinese learners tend not to volunteer to give information in class, and Chinese teachers prefer teacher centered activities more than Western teachers do (p. 27). Sato (1981) found that Asian students tend not to self select (p. 24). Students are reluctant to volunteer answers in case they are wrong.

Diane Fox (1989) interviewed Chinese students in America about their ways of learning. She writes:

Many students emphasized the importance of memorization... Several students told me memorization was for young people, old people could use logic and the wisdom of experience... Most Chinese students preferred to be scientists... since they were generally safe from political criticism. It was too dangerous to be a writer or an artist: they were always punished first. (p. 123)

Education in the U. S. A.

The values affirmed in American education will be outlined briefly in this section to provide an understanding of the different views given to education in the U. S. A. and the P. R. C.. These provide insights into the debate over language teaching in China.

American education began in imitation of European models with colonists forming schools which emphasized basic skills and doctrine in New England, highlighted ethnic and linguistic diversity in the middle eastern states, and reinforced white supremacy in the southern states (Gutek, 1986). Diversity has featured throughout the development of American education. The formation of the republic and civil war left education in the hands of 
each state but provided several guidelines: the goals of common education, equal opportunity, and patriotism. The lack of centralized education has resulted in much variation and the willingness to explore the direction and function of education. Sowell (1993) believes that modern education is subject to too many ideologies which subvert education by deviating from the school's primary focus of educating children in basic skills and developing their minds, to pursue 'educational brainwashing' where children are subjected to affective situations and peer pressure to change their values ( $p p$. 46-47). While this is obviously a pessimistic view, Sowell is one of many statistic wielding authors (including Stevenson and Stigler, 1992) claiming that education has in some way failed. Their presence serves as a reminder that, as in China, dissent is present in the U. S. A., but unlike China, dissent can be expressed.

Many key assumptions about education held in America stem back to the enlightenment, the theories which led to the rebellion from Britain. John Locke proposed the contract theory which stressed the rights of individuals to life, liberty, and property (Gutek, 1986, pp. 25-26). Locke posed that governments should be elected by, responsible to, and protective of the people. This contrasted with the concept of divine appointment: that God appointed the rulers of this world to rule the people. A second theory was linked to the contract theory: deism replaced theism such that a belief in a personal God was replaced by a belief in natural science and rational principles. The study of science was believed to lead to human perfection.

The above concepts have directly influenced education by encouraging (i) the separation of church and state, (ii) the focus on the individual, and (iii) the belief that universal education is essential to democracy. The separation 
of church and state meant that whereas the church had typically provided education for the first part of American history, the state would now take over that responsibility. A focus on individuals and individual rights led to the desire for universal education. The common school movement promoted free public education supported by state taxes. Universal education was not only seen as a right but as a necessity. Jefferson believed that for democracy to work and not degenerate into mob rule, people need to be educated (cited in Gutek, 1986, p. 41). The report from the President's commission on higher education for democracy of 1947 claimed that:

It is a commonplace of the democratic faith that education is indispensable to the maintenance and growth of freedom, of thought, faith, enterprise and association. Thus the social role of education in a democratic society is at once to ensure equal liberty and equal opportunity to differing individuals and groups, and to enable the citizens to understand, appraise and redirect forces, men and events as these tend to strengthen or weaken their liberties. (in Goodchild and Wechsler, 1989, p. 632)

Thus education was seen to be the social moderator: education acted to enforce democracy, instill patriotism, and allow for social mobility. Aronowitz writes:

At the turn of the twentieth century, Americans became convinced that education was the great democratic institution that enabled even the most humble of its citizens to enjoy the chance for selfimprovement... schools remained the hope of the hopeless. Once here, any American with the brains and initiative could become a professional. In effect, the road to intellectual labor replaced the frontier as the sustaining myth of American capitalist democracy. (1981, p. 1)

Some of the values attributed to education in America, are compared with those held in China in Table III. 
TABLE III

\section{A COMPARISON OF THE VALUES ATTRIBUTED TO EDUCATION IN AMERICA AND CHINA.}

\begin{tabular}{|c|c|}
\hline American educational views: & Chinese educational views: \\
\hline Education fosters democracy & - Education encourages socialism \\
\hline $\begin{array}{l}\text { - Educational achievement rests on } \\
\text { individual ability (S\&S, p. 94) }\end{array}$ & $\begin{array}{l}\text { - Educational achievement comes with } \\
\text { diligence and perseverance (S\&S, p. 94) }\end{array}$ \\
\hline \multirow{3}{*}{$\begin{array}{l}\text { Models are people with initiative, } \\
\text { leadership, and the desire to change } \\
\text { things (Lincoln, M. L. King). } \\
\text { Hard workers are 'nerds' (S\&S, p. 88) }\end{array}$} & $\begin{array}{l}\text { Models are those who work for the } \\
\text { collective. }\end{array}$ \\
\hline & \\
\hline & \\
\hline $\begin{array}{l}\text { - Children should be prepared for school by } \\
\text { their parents (S\&S, p. } 73 \text { ) }\end{array}$ & $\begin{array}{l}\text { - Children should be indulged by adults } \\
\text { before education begins ( } \& \& S, \text { p. } 73 \text { ) }\end{array}$ \\
\hline $\begin{array}{l}\text { - Once children start school, teachers have } \\
\text { most responsibility for children's } \\
\text { education (S\&S, p. 73) }\end{array}$ & $\begin{array}{l}\text { - Schooling begins the difficult transition to } \\
\text { the rational mind, children need parental } \\
\text { support. (S\&S, p. } 73 \text { ) }\end{array}$ \\
\hline $\begin{array}{l}\text { - Work competitively for the top grades and } \\
\text { positions. (W, p. } 77)\end{array}$ & $\begin{array}{l}\text { - Work together for collective achievement } \\
\text { (S\&S, p. 90) }\end{array}$ \\
\hline - Voluntary conformity (W. p. 83) & - External conforn \\
\hline $\begin{array}{l}\text { - Free expression of ideas, acceptance of } \\
\text { conflict, compromise necessary: creativity } \\
\text { encouraged (W, pp. 95-97) }\end{array}$ & $\begin{array}{l}\text { Restriction of ideas to the politically } \\
\text { correct, conflicting ideas suppressed: } \\
\text { conformity encouraged }\end{array}$ \\
\hline - Teacher purely instructional (H\&G, p. 76) & $\begin{array}{l}\text { - Teacher may also watch over students' } \\
\text { social and personal development (H\&G, p. } \\
\text { 77) }\end{array}$ \\
\hline $\begin{array}{l}\text { - Develop students to uphold democratic } \\
\text { principles }\end{array}$ & $\begin{array}{l}\text { - Develop students to uphold socialist } \\
\text { principles }\end{array}$ \\
\hline $\begin{array}{l}\text { - Equal opportunity for every person (H\&G, } \\
\text { p. 79) }\end{array}$ & $\begin{array}{l}\text { - Special opportunities for minorities, but } \\
\text { usually for the academically advantaged. }\end{array}$ \\
\hline $\begin{array}{l}\text { - Preferred mode of thinking inductive } \\
\text { (H\&G, p. 81) }\end{array}$ & $\begin{array}{l}\text { - Preferred mode of thinking deductive } \\
\text { (H\&G, p. 81) }\end{array}$ \\
\hline - Creative use of information (H\&G, p. 81) & - Recall of facts (H\&G, p. 81) \\
\hline - Books are a source of opinion (H\&G, p. 81) & - Books are a source of facts (H\&G, p. 81) \\
\hline $\begin{array}{l}\text { - Comments that teachers write on students' } \\
\text { work are considered private (H\&G, p. 83) }\end{array}$ & $\begin{array}{l}\text { - Comments written on a students' work are } \\
\text { public. Private communication spoken } \\
\text { (H\&G, p. 83) }\end{array}$ \\
\hline
\end{tabular}

Sources: H\&G = Hu \& Grove (1991), S\&S = Stevenson and Stigler (1992), and $\mathrm{W}=\mathrm{Webb}(1981)$. 


\section{VIEWS ABOUT LANGUAGE}

Language, particularly written language, has always been closely linked to power in China: the speech of the educated was full of proverbs, and of course they were literate. The Chinese script was viewed as difficult to learn and written texts were, for the most part, admired and respected. The attention given to literacy has been emphasized by Mao's literacy campaigns. These campaigns aimed to rid Chinese society of the distinction between the literate elite and illiterate majority, and by implication, the educated versus the uneducated classes. Mao assisted this change by calling for the simplification and standardization of characters.

Alley describes his experiences learning the Chinese language in the traditional method, from an old Manchu teacher. His teacher said "there's only one way to learn - start with the classics" (Burchett and Alley, 1976, p. 53). Alley learnt as a Chinese child would have, by progressing through three stages: (i) learning the 100 names (pai chia hsing) first verbally then written, (ii) reading the tri-metrical classics, (iii) learning and reading the qian zi wen the thousand character classics about heroes (Burchett and Alley, p. 53). The tradition of using ancient texts in teaching dates back to Confucius (500 BC). The Chinese language has always been regarded as difficult to learn because it is not based on a phonetic alphabet. Instead, the language began with pictographs and ideographs which have been stylized and simplified over the course of history ( $\mathrm{Li}, 1978$, p. 41). Most characters are composed of a radical and a signifier, one indicating meaning, the other giving approximate pronunciation. 
The importance of the written language for the Chinese people is further underscored when one realizes that in fact there are eight different Chinese dialects, all of which are mutually unintelligible. The dialects and the percentage of the population which speaks them are Putonghua (Mandarin), 71\%; Wu, 8\%; Xiang, 5\%; Cantonese, 5\%; Hakka, 4\%; Southern Min, 3\%; Gan, $2 \%$; and Northern Min 1\%. In addition five percent of the Chinese population speak other languages (Wardaugh, 1992, pp. 267-368). While the Chinese dialects are aurally distinct, they share a common written system. Wardaugh, a sociolinguist, suggests that it is the common written language of the Chinese dialects that makes China claim that the variations are separate dialects rather than languages. Westerners would probably conclude that since they are mutually unintelligible orally, they are therefore separate languages (1992, p. 26). The emphasis in China on the written language is to be expected because it acts as a necessary unifying factor in the midst of such variety. Mao aimed to make Putonghua a language common to all Chinese speakers. This has happened to a certain degree but Putonghua has limited use in areas where it is not the native dialect, and is certainly not replacing other dialects (Wardaugh, p. 368).

It is not surprising that with a history of valuing their own language, once contact with foreign countries became more regular, various other languages have been learnt. The Tong-wen Guan, or common-language school, began in Beijing, 1862, to teach English, French, Russian, German and Chinese. The next five years saw similar schools open in Shanghai, Guangzhou and Fuzhou (Hsu, 1990, pp. 270-271). More recently, Savada and Dolan report that since the nineteen-seventies, a foreign language, usually English, is introduced to school children in about third grade (1988, p. 161). 
English has grown to be the most frequently learned foreign language in China. Grabe and Mahon suggest the reason for this is the increased use of English as an international language for the communication of information. They comment "While not a sufficient condition for modernization by itself, English, is nevertheless a necessary link in the research and development system essential for modernization" (1982, p. 51).

Thus English learning in China tends to be un-emotive (in contrast with the motives of many Westerners going to China). Barton studied the correlation between the attitudes of Chinese students studying in America towards the American people and culture with their scores on the TOEFL (Test of English as a foreign language) and found that whereas Hispanics' attitudes towards American people and culture directly influenced their scores on the TOEFL, there was no significant relationship for Chinese students (cited in Young, 1987, p. 20). Of this, Young comments:

This corroborates the belief widely held by teachers and materials developers who have worked in both Western and Chinese communities, that while materials and methods which develop a positive attitude towards the target language culture are successful in the Western context, they are not necessarily relevant to Chinese students. (Young, p. 20)

The following section will examine how English has been taught, in the United States and in China.

\section{English language teaching}

Language teaching in the U.S.A. Language teaching in the United States has tended to follow the trends of other Western countries. From the fourteenth century AD, Latin was the language of education, commerce and religion; thus teaching the language emphasized language use. By the 
sixteenth century, French, Italian and English were competing with Latin for this status. Many advocated the learning of modern languages (Bowen, Madsen \& Hilferty, 1985, p.15). By the seventeenth century, Latin had lost many of its functions and was taught in an abstract manner: that is, Latin was not taught with the intention of being used, but as a system of grammar (Richards and Rodgers, 1986, p. 2). Grammar was studied systematically, each grammatical item was presented with several examples, and translation in and out of the target language provided practice. This method of teaching became known as the Grammar-Translation approach (Richards and Rodgers, p. 3). Emphasis was given to accuracy, isolated sentences, and deductive teaching of grammar. The native language of the students was used for instruction. The Grammar-Translation approach dominated up until the 1940s.

The Grammar-Translation approach did not exist without opponents. In the late eighteen hundreds, linguists emphasized speech (instead of the written word) as the primary form of a language, the study of phonetics began and linguists pushed for the reform of language teaching. They wanted language teaching to include the spoken language, conversational texts, inductive approaches and the use of the target language in classes (Richards and Rodgers, pp. 5-7). A popular reaction to the Grammar-Translation approach came in the form of the Natural approach, which believed that language teaching should emulate first language learning and concentrate on speech (Bowen, Madsen \& Hilferty, p. 20). The Direct approach was also developed in reaction to the Grammar-Translation approach. It differed from the Natural approach by claiming that learners of different ages and backgrounds learnt differently (Bowen, Madsen \& Hilferty, p. 25). Teachers 
were to use only the target language in the classroom, to use objects to teach new concrete words and to relate new abstract words to known vocabulary (Richards and Rodgers, pp. 9-11).

World War Two hastened the arrival of the 'army method' which utilized oral drills to teach languages to members of the armed forces. Renamed the Audiolingual approach after the war, this approach claimed that language learning occurred by the formation of habits through repetition (Bowen, Madsen \& Hilferty, pp. 33-34). Audiolingualism was received well, and achieved good results through the use of systematic textbooks, contextualized language practice, and a variety of activities (Bowen, Madsen \& Hilferty, pp. 36-37). The war also established English as an international language; hence English began to be taught.

Following Chomsky's derision of the Audiolingual approach, many diverse language teaching methodologies emerged. The approach which has gained the most acceptance and dominated American and Western language teaching since the Audiolingual approach is the Communicative approach. The Communicative approach assumes that language is learnt by students in order to communicate and thus that semantic notions and social functions will be taught alongside linguistic structures. Group work and authentic materials are used to facilitate contextual language use. The four language skills are integrated from the beginning and the teacher is expected to facilitate language learning and to be fluent in the target language (CelceMurcia, 1991, p. 8).

Richards and Rodgers present three views under which language methodologies can be classified: structuralist, functional and interactional. The structural view believes language to be a system of structurally related 
elements for the coding of meaning. The aim of learning for the structuralist, is mastery of the different aspects of language (phonology, grammar and the lexicon). Approaches which fall under the structural view include Audiolingualism and the Grammar-Translation approach. In contrast, the functional view sees language as a vehicle for the expression of functional meaning. Communication is emphasized and language teaching is based on categories of meaning rather than structure. The Communicative approach and English for Specific Purposes are included under the functional view. The interactional position views language as existing for interpersonal relationships and the performance of social transactions between individuals. Language is a tool for development and maintenance of social relations.

Students are involved in deciding what language is to be learnt (Richards and Rodgers, 1986, p. 17). The Affective Humanistic approach (see Celce-Murcia, 1991) is included under the interactional view. Richards and Rodgers' outline is helpful, as it separates clearly the ideological differences that separate the Audiolingual and Grammar-Translation approaches from the Communicative approach. It is not merely the procedures by which language is taught that differ but concepts about what language is and what language is used for that à:e disputed.

\section{History of English Language Teaching in China}

English teaching in China has reflected the political and educational policies of the nation (Benson, 1988, p.14). The English language has lost and gained popularity according to China's political ties and ideals. Since the period of the Four Modernizations, English has been identified as a key to development. Methods used to teach English in China have been influenced 
by political ties: that is, what language is taught and how it is taught have changed according to influences external to the field of language teaching. In contrast, changes in Western methodology have occurred independent of politics and have been influenced by quite different goals and ideals (such as humanitarianism). In practice this has resulted in equally as many changes; however, the changes have reflected pedagogical beliefs internal to the field of language teaching rather than political decisions. Table IV illustrates the influence of politics on language teaching in China and the contrasts between the language teaching methodologies held by China and the West. Table IV also highlights that many methods used then abandoned by Western countries were later adapted for use in China. This difference in time and an attitude of 'been-there-done-that' have been major causes of the negativism that Western language teachers have had towards Chinese teaching methods and the assumption that China should change, or become 'up to date'. For a concise explanation of the methodologies referred to in Table IV, see Celce Murcia (1991, pp. 3-11).

Political factors, however, are not the only factors that have influenced language teaching methodologies in China. Traditional assumptions about education and certain Western methods have also been influential. Traditionally, higher education in China consisted of analysis and memorization of texts (Grabe and Mahon, 1982, p. 51). The emphasis on literature has been transferred to the study of English, both as a component of language classes and as a separate field within TESOL in China. According to Grabe and Mahon (1982), China's language methodology is intensive reading (p. 51). Because English is a 'foreign' language in China, the lack of native speakers strengthens traditional language learning strategies of reading and 
TABLE IV

\section{AN OVERVIEW OF HISTORICAL EVENTS, EDUCATION, AND LANGUAGE TEACHING IN CHINA, AND WESTERN LANGUAGE TEACHNG METHODS}

\begin{tabular}{|c|c|c|c|}
\hline Historical Event: & Education in China: & $\begin{array}{l}\text { Foreign Language } \\
\text { Teaching in China: }\end{array}$ & $\begin{array}{l}\text { Western Language } \\
\text { Teaching method: }\end{array}$ \\
\hline Traditional trend & $\begin{array}{l}\text { Education for the rich } \\
\text { and rulers }\end{array}$ & $\begin{array}{l}\text { Foreign languages taught } \\
\text { to an elite }\end{array}$ & $\begin{array}{l}\text { Methods emphasized } \\
\text { language use or analysis }\end{array}$ \\
\hline $\begin{array}{l}\text { 1840: China defeated in } \\
\text { the first Opium war }\end{array}$ & $\begin{array}{l}\text { Foreign schools opened } \\
\text { in China }\end{array}$ & $\begin{array}{l}\text { Foreign schools taught } \\
\text { foreign languages } \\
\text { including English }\end{array}$ & $\begin{array}{l}\text { Grammar-translation } \\
\text { (GT) approach: language } \\
\text { analysis }\end{array}$ \\
\hline 1902 & $\begin{array}{l}\text { English included in the } \\
\text { school curriculum }\end{array}$ & $\begin{array}{l}\text { Grammar - Translation } \\
\text { approach }\end{array}$ & $\begin{array}{l}\text { Direct Method: language } \\
\text { use and GT }\end{array}$ \\
\hline $\begin{array}{l}\text { 1949: Cultural } \\
\text { Revolution }\end{array}$ & $\begin{array}{l}\text { Education the servant of } \\
\text { the proletariat }\end{array}$ & $\begin{array}{l}\text { Grammar - Translation } \\
\text { approach }\end{array}$ & $\begin{array}{l}\text { Reading Approach, } \\
\text { 1920s-40s: LL = reading }\end{array}$ \\
\hline $\begin{array}{l}\text { 1953: China becomes ally } \\
\text { of Russia. The first Five- } \\
\text { year plan }\end{array}$ & $\begin{array}{l}\text { Russian teaching } \\
\text { methods that focus on the } \\
\text { teacher, text \& classroom } \\
\text { are used }\end{array}$ & $\begin{array}{l}\text { English associated with } \\
\text { the enemies. English } \\
\text { replaced with Russian in } \\
\text { school curriculum }\end{array}$ & $\begin{array}{l}\text { Audio-Lingual 1940s- } \\
60 \text { s: structured oral } \\
\text { practice. LL = habit } \\
\text { formation }\end{array}$ \\
\hline 1955 & & $\begin{array}{l}\text { English returns to the } \\
\text { school curriculum }\end{array}$ & $\begin{array}{l}\text { Situational approach } \\
\text { 1940-60s: British peer to } \\
\text { audio-lingualism }\end{array}$ \\
\hline $\begin{array}{l}\text { 1958: The Great leap } \\
\text { forward }\end{array}$ & Renaissance of education & $\begin{array}{l}\text { Teaching materials } \\
\text { improved }\end{array}$ & Audio lingual dominates \\
\hline $\begin{array}{l}1959 \\
\text { 1960: Breakdown of } \\
\text { relations with USSR }\end{array}$ & $\begin{array}{l}\text { University exams } \\
\text { reintroduced. English in } \\
\text { university entrance } \\
\text { exams. } \\
\text { Russian experts leave }\end{array}$ & $\begin{array}{l}\text { 1960: English texts for } \\
\text { junior and middle schools } \\
\text { promote listening \& } \\
\text { speaking skills }\end{array}$ & Audio lingual dominates \\
\hline $\begin{array}{l}\text { 1966: Cultural } \\
\text { Revolution: Bourgeoisie } \\
\text { 'worst' level of society }\end{array}$ & $\begin{array}{l}\text { Teachers humiliated. } \\
\text { University exams } \\
\text { abolished: low student } \\
\text { motivation. English } \\
\text { ousted from school } \\
\text { curriculum }\end{array}$ & $\begin{array}{l}\text { Textbooks banned. } \\
\text { Foreign teachers accused } \\
\text { of being spies }\end{array}$ & $\begin{array}{l}\text { Cognitive Approach: LL } \\
\text { = rule acquisition. The } \\
\text { teacher must be } \\
\text { proficient }\end{array}$ \\
\hline $1969 / 70$ & $\begin{array}{l}\text { English returns to school } \\
\text { curriculum }\end{array}$ & Translation approach & $\begin{array}{l}\text { Affective-Humanist } \\
\text { Approach: affect in LL } \\
\text { examined }\end{array}$ \\
\hline $\begin{array}{l}\text { 1976: Mao dies. Gang of } \\
\text { Four overthrown. Major } \\
\text { reforms including } \\
\text { educational }\end{array}$ & $\begin{array}{l}\text { Attempts to raise } \\
\text { teacher's status. } 3 \text { major } \\
\text { high school subjects: } \\
\text { Chinese, Math, English }\end{array}$ & $\begin{array}{l}\text { English regained } \\
\text { popularity. 1979: junior } \\
\text { high + university entrance } \\
\text { exams include English }\end{array}$ & $\begin{array}{l}\text { Comprehension-Based } \\
\text { Approach: meaningful } \\
\text { input stressed. Basic } \\
\text { skill = Listening }\end{array}$ \\
\hline 1989: Tian'anmen Square & $\begin{array}{l}\text { University graduates no } \\
\text { longer guaranteed work } \\
\text { on completion of their } \\
\text { degree }\end{array}$ & $\begin{array}{l}\text { English desired for } \\
\text { reading journals }\end{array}$ & $\begin{array}{l}\text { Late } 1970 \text { s onwards: } \\
\text { Communicative } \\
\text { approach: stressed } \\
\text { communication and } \\
\text { authenticity }\end{array}$ \\
\hline The present trend & $\begin{array}{l}\text { Education important. } \\
\text { Uni. entrance exam based }\end{array}$ & $\begin{array}{l}\text { Reading translation } \\
\text { dominates }\end{array}$ & $\begin{array}{l}\text { Communicative } \\
\text { Approach dominates }\end{array}$ \\
\hline
\end{tabular}

Key: LL = Language Learning, Uni $=$ University

Sources: Celce-Murcia, 1991, pp. 3-11; Tang Lixing, 1983, pp. 38-48. 
memorization. In addition, the existence of a common written system but different spoken systems between dialects, has resulted in a greater use of writing for communication. Huang and Van Naerssen report that for the students they surveyed, reading techniques had even more significant correlation with oral communication ability than does speaking (1987, p. 295). Grabe and Mahon (1982) suggest that China's current emphasis on literature $\diamond$ fulfills the traditional notion of higher education as an analysis of texts and builds on the assumption that the study of literature is a sign that a student has passed beyond the mechanics as well as providing a general level of English for those with unclear job assignments (p. 51).

Because the Chinese language is learnt largely by memorization, memorization and rote learning are traditionally believed to be essential characteristics for successful language learning (Field, 1984, p. 176). These beliefs have been transferred to the study of other languages. Maley (1986) recognizes that this can be frustrating to the foreign teacher as views differ about whether language learning should be contextual/non-contextual, grammatical/intuitive, and so on (pp. 102-111). Wang remarks:

Chinese habits of teaching are deeply rooted in Chinese culture and the educational system. To change the habits completely is not as easy as some ESL specialists had thought. This leads to the suggestion of modification and compromise. It is a mistake for ESL teachers to arrive in China thinking that they have brought the good news in the form of [their] up-to-date methods and materials and it is equally a mistake for Chinese teachers and staff to dismiss foreign techniques and materials as irrelevant. (1988, p. 68)

The emphasis on memorization is also evidenced in university requirements. The amount of English that university students are required to know is 700 or 1000 words for the entrance examination and $1500-2000$ or 2500-3000 words by graduation; the larger figures are for English majors, the 
lower for non-English majors (Fox, 1989, p. 129). Those studying for a BA must do two years of language study. Those training to be foreign language teachers must study two languages (Moffett, 1983, p. 15).

The learning strategies employed by Chinese students have been found by Huang and Van Naerssen (1987) to fall into three categories: formal practice, functional practice, and monitoring (p. 289). Those employing functional practice (including communicative concepts) tended to be more successful language learners. However when 'less successful' learners attempted to use those techniques, often no improvement was shown ( $p$. 296). Pia (1989) found that the preferred learning styles of Chinese students studying English were various rather than showing general tendencies towards tactile, auditory, kinesthetic and visual (p. 57).

Pan (1984) categorized Chinese methods of language teaching into five groups: the nationwide structural-situational method based on realism; the structural-communicative method of Shanghai; the functional-communicative method of NE China; and the functional communicative approach based on semi-authentic language tasks of Guangzhou ${ }^{3}$. Pan concludes that the most widely used method is that of reading-translation (cited in Lieberman, 1984, pp. 18-19). Pan's first four categories indicate that the teaching of English in China has been influenced to some degree by Western methodologies, by making reference to concepts of function (what language is used for), structure (the structure of language, for example grammar and syntax), and the communicative approach (the belief that languages exist primarily for communication and that teaching methodology should reflect this by

3 Further definitions of these methods were not provided. 
teaching students how to communicate in the target language), all of which are stressed in Western methodology. Ye and $\mathrm{Li}$ comment:

The present way of teaching English in China is by no means totally grammar-translational as it was in the past. It is in the slow transition from teaching about the language to teaching the language under the impetus of the general syllabus. As the aims of teaching change so also the methods. Even in a very traditional class, more attention is being paid to learner's ability of using the language. (1988, p. 62)

The teaching of methodology classes has begun in several institutions; however, there is a tendency to see these as void of practical significance (Moffett, 1983, p. 14). In general, methodology is viewed as less important than proficiency: this conforms with political goals of modernization. Moffett reports that teachers are unsure about which methods to adopt but that their teaching is generally sound: "Most of them agree that the old grammar translation techniques are outmoded and ineffective and that regardless of the approach used the ultimate goal should be to develop communicative competence" (1983, p. 16). Wang (1993) encourages teachers to meet students' needs by "on the one hand exploiting the [learning] strategies learners already have, and on the other, assisting them to acquire new strategies" (p. 76). Klein et al. (1971) discuss the difficulties that foreign students in the United States experience. They comment: "If a student was expected at home to memorize texts and passively receive lectures, role conflict will be high for U.S. study settings where independent thinking and active challenge of traditional conceptions are highly valued" (p. 80). Where foreign teachers are actively encouraging a different system of learning in the home setting, as is often the case with foreign language teachers in China, role conflict may not be so clearly identified but the different set of expectations should not be overlooked. 


\section{CONCLUSIONS}

China has experienced a great deal of change over the last century. Since the turn of the century, two external wars have been fought (Japan, Korea), three different systems of government have ruled, and 6 internal conflicts, including 10 years of civil war, have been faced. China aimed to provide education for all members of society, but has struggled to supply the finances and resources needed to implement this goal; hence many, especially peasants, are dissatisfied. Universities have faced political censoring especially in the arts and humanities. Foreign languages were at times associated with external, politically-incorrect thinking and thus discouraged. Teacher-fronted classes and lecture style presentations are the most typical classroom procedures but other approaches have been tried. Although English has recently surfaced as the most desired foreign language and as a key to modernization, a comparison of English teaching methods in China and the United States yields few commonalities. 


\section{CHAPTER III \\ METHOD AND PROCEDURE}

\section{INTRODUCTION}

This chapter discusses how the research was performed. First the subjects and setting of the study are outlined. Then the data collection instruments and pilot test are described. Finally the processes for data analysis are outlined.

\section{SUBJECT AND SETTING}

The participants in this study are students or teachers of the English language drawn from seven universities in the People's Republic of China. The questionnaire was completed and returned by 347 students learning English and 34 teachers of English: approximately 50 students and 5 teachers from each university. The students ranged in age from 18 to 43 (the median was 21 years). The number of years that each student had spent at university ranged from 1 to 15 years (with a median of 2 years), including undergraduates and Ph.D. students. Of the 347 students, $63 \%$ were males, and $36 \%$ were females. The teachers ranged in age from 21 to 69 years (with a median of 30 years) and had been teaching for 1.5 to 32 years (median of 7 years). Of the 34 teachers, 9 were male and 25 were female. 
The seven universities were selected on the basis of knowing acquaintances of current or former teachers at the institution. Each of the seven universities is situated in a different province: Anhui Medical University (Anhui province), Hunan Medical University (Hunan), First Military Medical University (Guangzhou), Zhengzhou University (Henan), Jianghan Petroleum Institute (Hubei), Laochun Teachers College (Shandong), and Nankai University (Tianjin). The location of each university in relation to each other is shown in Figure 2.

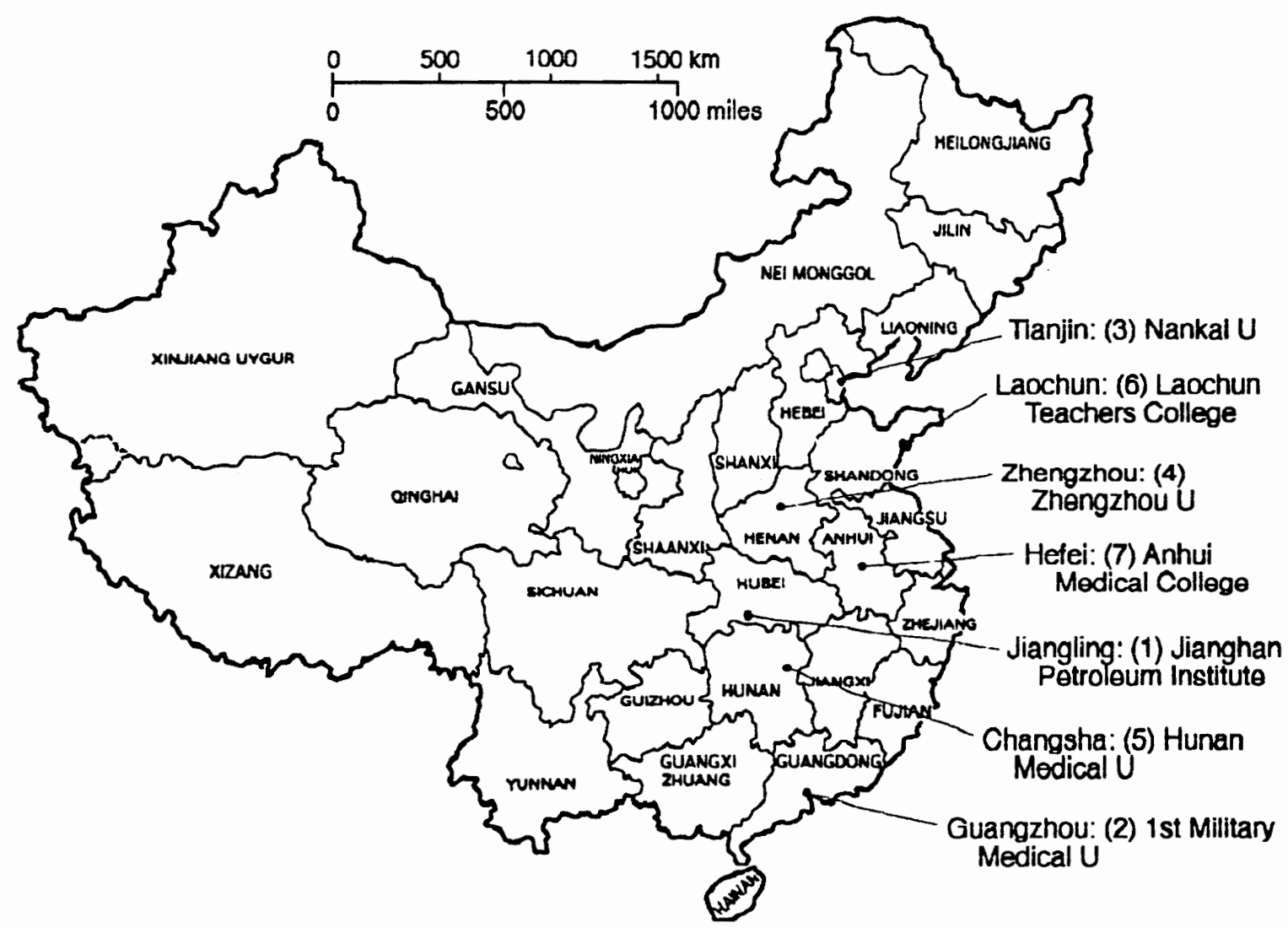

Figure 2. Map of China showing provincial boundaries and the cities where the seven universities are situated. The number in parentheses indicates the order in which the questionnaires were returned and in which the universities are grouped for analysis. 
These universities represent a range of well to little known; large to small; general to specific institutions. For example, Nankai University is a large northern university with a professorial staff of 318 and an additional 1300 lecturers and assistants. In contrast, Jianghan Petroleum Institute is a small institution owned by an oil field, located in a rural setting, which focuses on technology associated with oil drilling.

\section{PROCEDURE}

Correspondence was sent to one teacher at each university. Let us call these teachers the coordinators. Each coordinator received 50 student questionnaires, 5 teacher questionnaires, a stamped addressed postcard, a stamped addressed return envelope, and a small book of short stories by O'Henry as a gesture of thanks. The coordinators were asked to return the postcard on receipt of the questionnaires as an indication that the packet had been received.

The coordinator was then asked to distribute as many questionnaires as was possible and convenient amongst their most advanced class of students. This stipulation did not intend to target only upper division students, but, since most English classes occur at the compulsory level (1st and 2nd year), it was included to increase the likelihood of including upper division students in the study.

The coordinators were also asked to distribute the questionnaire amongst interested English-teaching colleagues. The teacher questionnaires were printed on blue paper so that they could be easily distinguished from the white student questionnaires. Each participating teacher was asked if they 
would like to receive a summary of the data: summaries were sent to the coordinators.

When the questionnaires had been completed, the coordinator was asked to collect and return them to the U.S. in the enclosed stamped and addressed envelope.

The teachers were asked to participate, but were under no obligation to do so. Each teacher and student questionnaire included a brief summary of the project, a statement that it was voluntary for them to participate, and a place to indicate their consent. If they did not wish to participate, they were asked to return the blank questionnaire to the English teacher who had given it to them. In addition to the space in which consent was indicated, participation implied consent. All participants were asked to remain anonymous by not signing the questionnaire.

Postage time was calculated as two weeks each way plus one to three weeks for the questionnaires to be filled out. Henderson (1993) writing about survey research in China, warns her readers to "remember that each stage will always take longer than you think" (p. 33). Mailed questionnaires usually have a fairly low response rate: sixty percent is a reasonable return (Frey, et al., 1991, p. 194). However, almost one hundred percent were returned: $347 / 350$ student questionnaires (99.1\%) and 34/35 teacher questionnaires (97.1\%) over a period of four to six weeks from the time that they were sent from Portland.

\section{INSTRUMENTS}

The questionnaires were presented as a four sided booklet, to ensure that no pages were misplaced. Students were sent questionnaires written in simplified Chinese characters, and teachers were sent questionnaires written 
in English. The guidelines from which the questionnaire was written, are outlined in Appendix A.

The questionnaire fell roughly into three sections, the first relating to demographic information, the second asking about language use, and the third asking about the respondents' views about language, language learning and education. Closed questions (where a set of rating terms are provided, as in multiple choice questions) were chosen in preference to open questions (in which the writers respond as they wish) except for a few demographic questions, to avoid problems of translation and responses that were off the topic. Individual items were constructed with the intention of being clear, free of jargon and cultural references, and in a simple format. All three questionnaires (the student questionnaire in English, the student questionnaire in Chinese, and the teacher questionnaire in English) can be found in Appendix B.

The categories under which data were collected included questions about the contexts in which the learner will be using English, reasons for studying English, the learners' views about language, language learning and education.

In the first section, which was largely demographic (questions 1-24), students were asked if they had been taught by a native English speaker, and whether this teacher taught in a way that was similar to or different from their Chinese teachers. These questions aimed to discover whether the students' views had been influenced by Western ideology. Similarly the students were asked if they were studying for an external English proficiency exam (such as the TOEFL and GMAT) to see if this altered their views about language learning. In addition to the core questions from the student survey 
(items 1-5, 13-62), English teachers were asked several questions regarding their training. Students and teachers were both asked whether, for each language skill, grammar and literature, they preferred Chinese or English speaking teachers and Chinese or Western methods of teaching.

In the second section of the questionnaire (questions 25a-40b) each question required two responses relating to the importance and frequency of the action under investigation. Individual items elicited the degree to which various English skills were necessary; where English would be used; and in what situations. The perceived importance and estimated frequency of each item was ranked by the participants using two Likert scales. The importance scale ranged from not important (1) to extremely important (5). The frequency scale ranged from never (1) to always (5). This section was linked to research question number four.

The third section of the questionnaire (questions 41-62) asked questions that related specifically to different views about language, language learning and education. Each item was selected to represent different language views, educational views and methodological or language learning views. Each item is listed with the viewpoint(s) it represents in Table V. This section is linked to research questions one, two, three and five.

\section{PILOT TESTING}

The student questionnaire was pre-tested on four students from the People's Republic of China. The four students ranged in language ability. The students spent between ten and twenty minutes completing the questionnaire and were encouraged to state which sections were difficult or unclear. From their comments, several questions were eliminated, others re-written, and 
TABLE V

VALUES UNDERLYING QUESTIONNAIRE ITEMS 41 TO 62

\begin{tabular}{|c|c|c|c|c|c|}
\hline & Item: & $\begin{array}{l}\text { Research } \\
\text { Question: }\end{array}$ & $\begin{array}{l}\text { Approaches } \\
\text { which } \\
\text { Agree } \\
\end{array}$ & $\begin{array}{l}\text { Approaches } \\
\text { which } \\
\text { Disagree } \\
\end{array}$ & $\begin{array}{l}\text { Approach } \\
\text { considered in } \\
\text { analysis }\end{array}$ \\
\hline 41. & The purpose of language is communication & 1 & $\mathrm{CA}, \mathrm{CP}, \mathrm{SA}$ & & $\mathrm{CA}$ \\
\hline 42. & A language is made up of many rules & 1 & GT, $\operatorname{Cog}, A L$, & $\mathrm{DA}, \mathrm{CA}$ & GT \\
\hline 43. & $\begin{array}{l}\text { A language is best learnt by separately learning } \\
\text { language areas such as grammar, phonology, and } \\
\text { vocabulary }\end{array}$ & 1,2 & GT RA, AL, & $\mathrm{CA}$ & GT \\
\hline 44. & $\begin{array}{l}\text { A language consists of social and cultural } \\
\text { elements as well as linguistic elements }\end{array}$ & 1 & $\frac{C A}{C P}, D A, S A$, & & $\mathrm{CA}$ \\
\hline 45. & The best way to learn a language is to study it & 2 & GT & $\mathrm{CP}$ & GT \\
\hline 46. & The best way to learn a language is to use it & 2 & $\mathrm{CA}, \mathrm{CP}, \mathrm{AL}$ & $\mathrm{GT}$ & $\mathrm{AL} \& \mathrm{CA}$ \\
\hline 47. & $\begin{array}{l}\text { The teacher should only use English during } \\
\text { English language classes }\end{array}$ & 2 & $\begin{array}{l}\mathrm{CA}, \underline{\mathrm{SA}}, \mathrm{DA}, \\
\mathrm{CP}\end{array}$ & GT, AL, RA & $A L \& C A$ \\
\hline 48. & $\begin{array}{l}\text { Diaiogs included in textbooks should be practiced } \\
\text { each lesson }\end{array}$ & 2 & $\mathrm{DA}, \underline{\mathrm{AL}}$ & & $\mathrm{AL}$ \\
\hline 49. & $\begin{array}{l}\text { Speaking and listening skills should be learnt } \\
\text { before reading and writing }\end{array}$ & 2 & $\mathrm{SA}, \mathrm{AL}, \mathrm{DA}$ & $\mathrm{RA}, \mathrm{GT}, \mathrm{CP}$ & $\mathrm{AL}$ \\
\hline 50 . & The teacher should explain grammar clearly & 2 & GT, RA, SA, & $\begin{array}{l}\mathrm{DA}, \mathrm{AL}, \mathrm{CP}, \\
\mathrm{IA}\end{array}$ & GT \\
\hline 51. & $\begin{array}{l}\text { The language learner has more responsibility for } \\
\text { his or her learning than the teacher }\end{array}$ & 2 & CA, Cog & & CA \\
\hline 52 & It is good for students to make language errors & 2 & $\mathrm{CA}, \operatorname{Cog}, \mathrm{CP}$ & $\mathrm{AL}, \mathrm{DA}$, & $A L^{\prime}($ ie not $A L)$ \\
\hline 53. & $\begin{array}{l}\text { The language teacher should teach at a level just a } \\
\text { little higher than I am at }\end{array}$ & 2 & $\mathrm{CA}, \mathrm{CP}$ & & $\mathrm{CA}$ \\
\hline 54. & $\begin{array}{l}\text { Reading, Writing, Speaking and Listening are } \\
\text { equally important language skills }\end{array}$ & 2 & $\operatorname{Cog}, \mathrm{CA}$ & SA RA, CP & $\mathrm{CA}$ \\
\hline 55. & $\begin{array}{l}\text { During class, I should practice using the English } \\
\text { language with small groups of other students }\end{array}$ & 2 & $\mathrm{CA}, \mathrm{SA}$ & & $\mathrm{CA}$ \\
\hline 56. & $\begin{array}{l}\text { Students should repeat words and sentences after } \\
\text { the teacher }\end{array}$ & 2 & $\underline{\mathrm{AL}}$ & $\mathrm{CP}$ & $\mathrm{AL}$ \\
\hline 57. & I prefer to work out language rules by myself & 2 & $\frac{\mathrm{DA}}{\mathrm{CP}}, \mathrm{AL}, \underline{\mathrm{IA}}$ & RA, GT, & GT (ie not GT) \\
\hline 58. & Education is learning how to learn & 3 & Western & & ED \\
\hline 59. & $\begin{array}{l}\text { Students should feel free to interrupt the teacher } \\
\text { with questions and comments at any time }\end{array}$ & 3 & Western, CA & & ED \\
\hline 60. & $\begin{array}{l}\text { Education occurs primarily through extensive } \\
\text { reading }\end{array}$ & 3 & Chinese, GT & & ED \& GT \\
\hline 61. & Students should choose what they learn in school & 3 & Western & & ED \\
\hline 62. & The aim of education is to get a good job & 3 & Western & & $\mathrm{ED}$ \\
\hline
\end{tabular}

Key: $\mathrm{CA}=$ Communicative Approach; $\mathrm{Cog}=$ Cognitive Approach; $\mathrm{GT}=$ Grammar Translation; $\mathrm{SA}=$ Situational Approach; $\mathrm{DA}=$ Direct Approach; $\mathrm{AL}=$ Audiolingual; $\mathrm{RA}=$ Reading Approach; $\mathrm{CP}=$ Comprehension Approach; IA = Inductive Approach . $\mathrm{ED}=$ Educational view. An underlined abbreviation is central to the approach. 
two sections were re-formatted. It was this version of the questionnaire which was translated into Chinese characters.

The teacher questionnaire was not pretested, being for the most part identical to the student questionnaire with the exception of several demographic questions and variation in 'person' in sections two and three (that is, "the students use English..." rather than "I use English..."). It was anticipated that teachers would have less difficulty with the questionnaire as it dealt with components of their work. The teacher questionnaire was not translated into Mandarin.

\section{MEANS OF ANALYSIS}

The data were analyzed in several ways. Firstly descriptive statistics (the mean, and standard error of the mean) were used to gain an overview of the responses. Secondly, the data were analyzed for correlations. Thirdly factor analysis was applied to look for underlying patterns in items 13-24, 25a$40 \mathrm{a}, 25 \mathrm{~b}-40 \mathrm{~b}$, and 41-62. Finally ANOVA were used to test group homogeneity. These tests are discussed in greater detail below.

\section{DESCRIPTION OF STATISTICAL TESTS}

The data from each questionnaire was entered into the data base of a statistical program called JMP. From this data base, statistical summaries could be generated for one student, the whole group, or for groups of students with a common feature: for example, students from the same school or students that had been taught by a native English speaker. Descriptive 
statistics were obtained by generating a histogram of responses to an item or calculating the mean and its standard error.

The descriptive data are displayed in the form of a response profile. The response profiles plot the mean response for each item with standard error bars (one standard error each side of the mean). When the error bars for different groups do not overlap, a significant difference exists between the groups for that item.

Correlations are used to examine the relationship of responses to a pair of items. When items correlate highly, it was possible, given the response to one item, to predict subjects' responses to the second item.

Factor analysis goes one step beyond correlation by attempting to summarize the responses to a group of questions (for example questions 1324) with a low number of measures, called factors. A good factor has a clear conceptual interpretation as well as strong summarizing capacity in a numerical sense. The derived set of factors represents the questionnaire responses compactly and without decreasing its descriptive ability. The reduced set of measures facilitates efficient data analysis and clear interpretation. An excellent description of how factors are calculated and interpreted is given by Tabachnick and Fidell (1983). The original factors are not always interpretable. That is, together they summarize the data well, but individually they are unable to be interpreted. By rotating the factor axes, the factors may become interpretable and retain essentially all their summarizing ability (see Tabachnick and Fidell, 1983, p. 399).

ANOVA (analysis of variance) takes one of the above factors, or an individual item and looks for variation between the responses to that item by two or more subject groups. ANOVA seeks to disprove the null hypothesis 
that the two plus groups are drawn from the same parent population and that their means are therefore the same. When the means differ more than chance would allow, the null hypothesis is rejected and the groups are presumed not to have been drawn from the same population. ANOVA is employed in this study to examine whether or not demographically defined groups of subjects represented a single response set for a given factor or questionnaire item. In other words, did members of the groups respond the same as, or different from the complete group. The alpha level was set at 0.05 , i.e., only those items for which there was a less than $5 \%$ chance of having falsely rejected the null hypothesis were considered significant.

Given the situation that the null hypothesis was rejected, the ANOVA test alone does not indicate "which means differed significantly from which other means" (Glass \& Hopkins, 1984, p. 368). The procedures used to search for significant differences in means are collectively known as multiple comparison techniques. The technique used in this study was the Tukey method with alpha $=0.05$. 


\section{CHAPTER IV}

\section{RESULTS}

\section{INTRODUCTION}

This study utilized a survey design and aimed to "obtain a snapshot of conditions, attitudes or events at a single point in time" (Nunan, 1992, p. 140). This chapter describes that picture. The description of results parallels the four sections of the questionnaire. That is, questions 1-12, 13-24, 25-40, and 4162 are discussed as groups. The demographic section (questions 1-12) provides a summary of the respondents using descriptive statistics. In addition to descriptive data, three inferential tests were used to analyze the remaining sections: correlation, factor analysis, and ANOVA.

\section{SUMMARY OF FINDINGS}

\section{Demographic data}

Section one of the questionnaire (questions 1-12) elicited demographic data from the subjects. A summary of this information can be found in Table VI.

Students Roughly two-thirds of the student respondents were males whose first language was a Chinese dialect other than Mandarin. The average age was 22 years and the mean length of university study was 3.1 years.

Approximately one-sixth were English majors. The majority of students had 
not learned a foreign language in addition to English. Those who had studied another foreign language typically chose Russian, German or Japanese (French, Latin and Esperanto had also been learned by a few respondents).

\section{TABLE VI}

DEMOGRAPHIC CHARACTERISTICS OF RESPONDENTS

\begin{tabular}{|c|c|c|c|c|c|c|c|c|c|c|c|c|c|c|c|c|}
\hline & \multirow{2}{*}{ Count } & \multicolumn{2}{|c|}{ Age (years) } & \multicolumn{2}{|c|}{ Gender } & \multicolumn{3}{|c|}{ Native Language } & \multicolumn{2}{|c|}{$\begin{array}{l}\text { Fls known } \\
\text { (excluding } \\
\text { E) }\end{array}$} & \multicolumn{2}{|c|}{$\begin{array}{l}\text { Years } \\
\text { English } \\
\text { studied }\end{array}$} & \multicolumn{2}{|c|}{$\begin{array}{l}\text { Years of } \\
\text { University } \\
\text { study }\end{array}$} & \multirow{2}{*}{$\begin{array}{l}\text { Sudying } \\
\text { for an } \\
\mathrm{EE} \\
\text { Count }\end{array}$} & \multirow{2}{*}{$\begin{array}{l}\text { Have } \\
\text { had a } \\
\text { NES T } \\
\text { Count }\end{array}$} \\
\hline & & Mean & SE & Male & Female & Mand & $O D$ & E & 1 & $2+$ & Mean & $\mathrm{SE}$ & Mean & SE & & \\
\hline Teachers & 34 & 33.6 & 10.6 & 9 & 25 & 23 & 9 & 5 & 18 & 4 & 12.4 & 4.7 & 4.47 & 0.88 & n/a & 19 \\
\hline Students & 347 & 22.3 & 0.18 & 219 & 127 & 116 & 226 & 0 & 67 & 9 & 9.1 & 0.12 & 3.3 & 0.12 & 51 & 136 \\
\hline
\end{tabular}

Key: $\mathrm{SE}=$ Standard Error, Mand $=$ Mandarin, $\mathrm{OD}=$ Other Dialect, E. = English, FLs $=$ Number of Foreign Languages, EE = external exam, NES T = Native English Speaker as a teacher (the native English speakers taught teachers teaching methods and students English)

Students had on average learned English for nine years, and 136 of 347 (39.2\%) students had at some time been taught by a native English speaker. Those students who had been taught English by a native speaker were asked whether that teacher taught in a way that was similar to or different from their Chinese teachers: 5 said similar, 128 said different. Twenty-seven students who had not had a native speaker teach them answered the second question (these students are not included in the above totals): 23 of these guessed the teacher would teach differently from their Chinese teachers.

Students were asked to indicate the subjects for which they need English in question 12. This question appeared to have been translated incorrectly, and reads "If I were in this profession, would I use English?" rather than asking what profession the student needs English for personally. 
Hence many students circled over five subjects or professions that were unlikely to be studied together. This question may have gained a better response if it focused solely on profession or was written as:

(a) I am studying/want to work in the field of... (circle a maximum of 3);

(b) I will need to use English once I have graduated Yes/No; and

(c) If yes, which subject will you need English for?

This interpretation of question 12 is not completely meaningless. It appears to indicate that English is needed in China for subjects that China is not strong in. The order in which the subjects/professions were ranked are listed in order from most to least needed: Computer science (268), Commerce (248), Medicine (245), Service (230), Science (210), Education (206), Engineering (128), Social Science (121), Humanities (113), Mathematics (93), Administration (87), Army (76), Other (46).

Teachers The average teacher was 33.6 years old, and in 25 of the 34 cases, female. Of the teachers, the majority had learned Mandarin as their native language and had learned at least one foreign language besides English. The average length of time they had studied at university was 4.4 years and the average number of years teachers had taught was 9 years.

Both students and teachers were asked to rate their own English proficiency. Their responses are shown in Table VII. The majority of students (220) responded $3=$ average, and only 2 responded $5=$ very good. The majority of teachers responded $4=$ good, with 10, (including 5 native English speakers), responding very good. Several of the coordinators wrote a short description of their students which they returned with the questionnaires (Appendix C). All the students from Nankai University are first year Ph.D. students in a variety of subject areas, from all over the country. Two of the teachers who responded from Nankai are Americans. The students from 
TABLE VII

TEACHERS AND STUDENTS SELF EVALUATION OF ENGLISH PROFICIENCY.

\begin{tabular}{|l||ll|ll|ll|ll|ll|}
\hline & $1=$ poor & 2 fair & $3=$ average & $4=$ good & $5=$ very good \\
\hline \hline $\begin{array}{l}\text { Teachers } \\
(\mathrm{n}=34)\end{array}$ & $0 \%$ & $\mathrm{n}=0$ & $0 \%$ & $\mathrm{n}=0$ & $6 \%$ & $\mathrm{n}=2$ & $65 \%$ & $\mathrm{n}=22$ & $29 \%$ & $\mathrm{n}=10$ \\
\hline $\begin{array}{l}\text { Students } \\
(\mathrm{n}=347)\end{array}$ & $12 \%$ & $\mathrm{n}=42$ & $13 \%$ & $\mathrm{n}=46$ & $63 \%$ & $\mathrm{n}=220$ & $9 \%$ & $\mathrm{n}=32$ & $0.6 \%$ & $\mathrm{n}=2$ \\
\hline
\end{tabular}

Please Note: there are 5 Native English teachers included in column 5.

Zhengzhou University are all postgraduates. The students from Hunan Medical University are undergraduate students of medicine who were selected randomly after an English class. The students at this school have a reputation for doing well in national English exams (College English Tests). The coordinator from Anhui Medical University said that 35 students were from the low or intermediate English classes, 15 were from higher classes. She said:

Most of the students from our university are from the rural area. Before entering into this university, they studied English only with a textbook and an English teacher. After graduation, most of them will have to go back to their hometown to work where English is seldom used. (private correspondence)

No additional information was given about the students from Jianghan University, the First Military Medical University or Laochun Teachers College, but we can deduce from Table VIII much of the same information.

\section{PREFERRED TEACHERS AND METHODS}

The group of questions 13-24 contains two parallel sub-sections. Questions 13-18 asked respondents whether, for their teacher of reading, 
TABLE VIII

\section{DEMOGRAPHIC DATA BY UNIVERSITY}

\begin{tabular}{|c|c|c|c|c|c|c|c|c|c|c|c|c|c|c|c|c|c|}
\hline & & \multicolumn{2}{|c|}{$\begin{array}{l}\text { Jianghan } \\
\text { Petrolium } \\
\text { Institute }\end{array}$} & \multicolumn{2}{|c|}{$\begin{array}{l}\text { 1st Military } \\
\text { Medical } \\
\text { University }\end{array}$} & \multicolumn{2}{|c|}{$\begin{array}{l}\text { Nankai } \\
\text { University }\end{array}$} & \multicolumn{2}{|c|}{$\begin{array}{l}\text { Zhengzhou } \\
\text { University }\end{array}$} & \multicolumn{2}{|c|}{$\begin{array}{l}\text { Hunan } \\
\text { Medical } \\
\text { University }\end{array}$} & \multicolumn{2}{|c|}{$\begin{array}{l}\text { Laochun } \\
\text { Teachers } \\
\text { College }\end{array}$} & \multicolumn{2}{|c|}{$\begin{array}{l}\text { Anhui } \\
\text { Medical } \\
\text { University }\end{array}$} & \multicolumn{2}{|c|}{ Total } \\
\hline Respondants & (count) & 5 & 50 & 5 & 50 & 5 & 47 & 5 & 50 & 4 & 50 & 5 & 50 & 5 & 50 & 34 & 347 \\
\hline \multirow[t]{2}{*}{ Age (in years) } & Mean & 31.8 & 20.3 & 27.6 & 19.9 & 34.2 & 27.6 & 36.8 & 24.9 & 35.0 & 21.2 & 37.5 & 21.8 & 33.4 & 20.9 & 33.6 & 22.3 \\
\hline & SE & 5.02 & 0.29 & 5.02 & 0.29 & 5.02 & 0.31 & 5.02 & 0.29 & 5.02 & 0.29 & 5.61 & 0.29 & 5.02 & 0.29 & 10.6 & 0.18 \\
\hline \multirow[t]{2}{*}{ Gender } & Male & 2 & 29 & 3 & 44 & 0 & 38 & 1 & 32 & 2 & 23 & 1 & 21 & 1 & 32 & 9 & 219 \\
\hline & Female & 3 & 20 & 2 & 6 & 5 & 9 & 4 & 18 & 2 & 27 & 4 & 29 & 4 & 18 & 25 & 127 \\
\hline \multirow[t]{3}{*}{ Native Language } & Mand & 2 & 20 & 3 & 18 & 2 & 24 & 4 & 16 & 4 & 15 & 2 & 8 & 2 & 15 & 23 & 116 \\
\hline & OD & 3 & 28 & 2 & 32 & 0 & 23 & 1 & 32 & 1 & 35 & 0 & 42 & 3 & 34 & 9 & 226 \\
\hline & $\mathrm{E}$ & 0 & 0 & 0 & 0 & 3 & 0 & 0 & 0 & 0 & 0 & 2 & 0 & 0 & 0 & 5 & 0 \\
\hline \multirow{2}{*}{$\begin{array}{l}\text { Foreign Language } \\
\text { (in addition to E) }\end{array}$} & 1 & 4 & 0 & 2 & 0 & 4 & 24 & 1 & 4 & 4 & 4 & 0 & 35 & 3 & 0 & 18 & 67 \\
\hline & $2+$ & 1 & 0 & 0 & 0 & 0 & 9 & 0 & 0 & 0 & 0 & 1 & 0 & 2 & 0 & 4 & 9 \\
\hline \multirow[t]{2}{*}{ Years Studied E } & Mean & 8.4 & 7.9 & 14.4 & 7.8 & 12.0 & 12.1 & 15.6 & 9.5 & 14.6 & 9.2 & 12.0 & 8.8 & 9.2 & 8.3 & 12.4 & 9.1 \\
\hline & SE & 1.9 & 0.26 & 1.9 & 0.26 & 3.0 & 0.26 & 1.9 & 0.27 & 1.9 & 0.26 & 3.0 & 0.26 & 1.9 & 0.26 & 4.7 & 0.12 \\
\hline \multirow[t]{2}{*}{ Years of U Study } & Mean & 4.8 & 1.9 & 4.8 & 1.7 & 4.9 & 7.5 & 4.4 & 4.9 & 4.25 & 2.8 & 4.25 & 2.5 & 3.8 & 2.0 & 4.47 & 3.3 \\
\hline & SE & 0.47 & 0.14 & 0.47 & 0.14 & 0.47 & 0.14 & 0.47 & 0.14 & 0.53 & 0.14 & 0.53 & 0.14 & 0.47 & 0.14 & 0.88 & 0.12 \\
\hline External Exam & (count) & $n / a$ & 7 & $\mathrm{n} / \mathrm{a}$ & 4 & $n / a$ & 8 & $n / a$ & 12 & $\mathrm{n} / \mathrm{a}$ & 9 & $\mathrm{n} / \mathrm{a}$ & 3 & $\mathrm{n} / \mathrm{a}$ & 8 & $n / a$ & 51 \\
\hline Taught by NS & (count) & 3 & 16 & 1 & 5 & 4 & 45 & 3 & 12 & 3 & 5 & 1 & 50 & 4 & 3 & 19 & 136 \\
\hline
\end{tabular}

Key: T = Teachers, S = Students, SE = Standard Error, Mand = Mandarin, OD = Other Dialect, E. = English, U = University, NS = Native English Speaker (NS taught teachers teaching methods and students English) 
writing, speaking, listening, grammar and literature, they preferred native speakers of Chinese, native speakers of English, or whether they had no preference. Questions 19-24 asked the respondents whether or not they had a preference for Chinese or Western teaching methods for the same six language classes.

The mean responses for questions 13-24 are presented in Figure 3. The mean responses of the teachers are displayed as a solid line and the student means as a dotted line. The standard errors of the student means are considerably smaller than those of the teachers due to the larger sample size (347 compared with 34). An error bar represents one standard error above and one standard error below the mean. From Figure 3 we can see that, with the exception of questions 13 (reading teacher), 18 (literature teacher) and 24 (literature method), the patterns of the student and teacher responses are

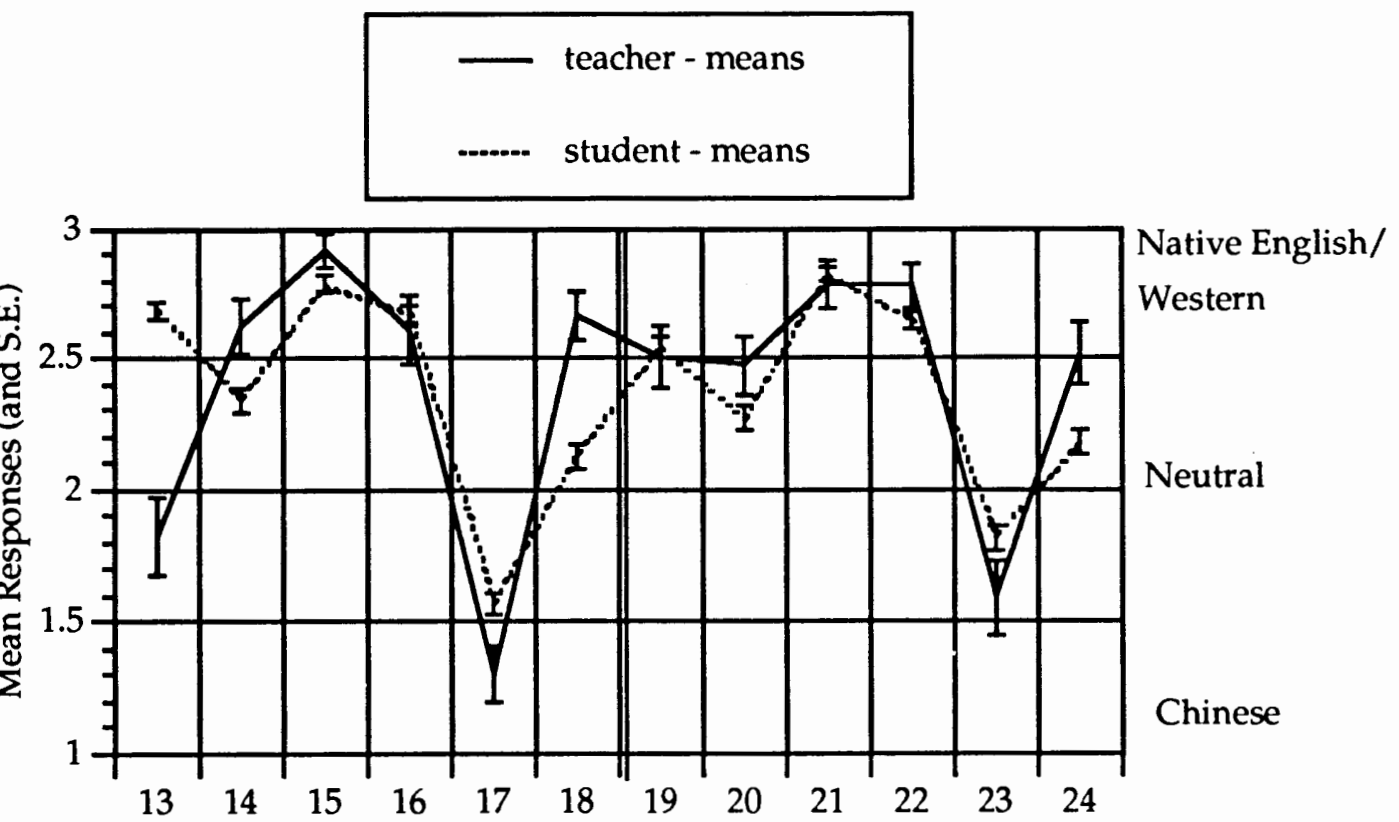

Questions: 13-18 = Teacher Prefered, 19-24 = Method Prefered

Figure 3. Mean responses of Teachers and Students to questions 13-24. 
similar. In fact, the correlation between the mean responses of the teachers and the mean responses of the students is 0.713 .

Students preferred native speaker teachers and Western methods for the four language skills; Chinese teachers for Grammar; and either teacher or method for literature classes. Teachers differed from the students by preferring western methods and native-English-speaking-teachers for literature, and having no preference about teachers of reading.

The respondents appeared to relate the teacher of a course with the method used to teach it. This was confirmed by significant correlations. For each of the modes (Reading, Writing, Speaking, Listening, Grammar and Literature), students choice of teacher (Chinese, either, or English) correlates with the method of teaching (Chinese, either, or Western) at the level of (0.393-0.483) or above with the exception of reading which only had a correlation of 0.287 .

Factor analysis of questions 13 to 24 . Using factor analysis, four factors emerged: speaking + listening $(15,16,21,22)$; literature $(18,24)$; reading + writing $(13,14,19,20)$; and grammar $(17,23)$. However the factors with four items had weak correlations between different modes: For example in Factor 1 the relationship between students' response to question 15 (teacher of reading) and question 22 (method for writing) has a correlation of 0.261 . Thus, for questions 13-24, the teacher and method will be combined for each mode and treated as a factor. The mean student responses for each of the six modes show that students prefer English teachers who use Western methods to teach reading, writing, speaking and listening. They prefer Chinese teachers for grammar, and are more or less neutral over who teaches them and how they are taught literature. 
While there is a relation between how teachers and students rated questions 13-24, the factors which emerge from the teachers' responses are different from those of the students. The correlations between the teacher and method used to teach each subject range from -0.065 (speaking) to 0.4774 (grammar). Six high factors emerge but they do not seem meaningful. Factor analysis of relatively small groups such as the teachers in this survey $(\mathrm{N}=34)$, can easily be unstable. When the results of the factors of the teacher data seemed unclear, the parallel results from the student data were used. In the case of questions 13-24, student factors were used.

ANOVA was used to compare various groups of respondents' mean responses to questions 13-24. Figure 4 indicates that, besides the comparison of teachers and students which has already been discussed, the most interesting group response came from the breakdown into schools. In general the responses of one school ran parallel to the responses of another school. However, Nankai university students differed dramatically from other schools with regard to responses for writing, preferring Western methods and teachers. Anhui Medical University stood out from other respondents with their preference for the speaking mode. A summary of responses by groups of respondents to questions 13-24 in the form of plots of factor responses, can be found in Section A of Appendix D. The graphs show that English majors tended towards the extremes and that teachers preferred Western teachers and methods for classes on writing and speaking. 

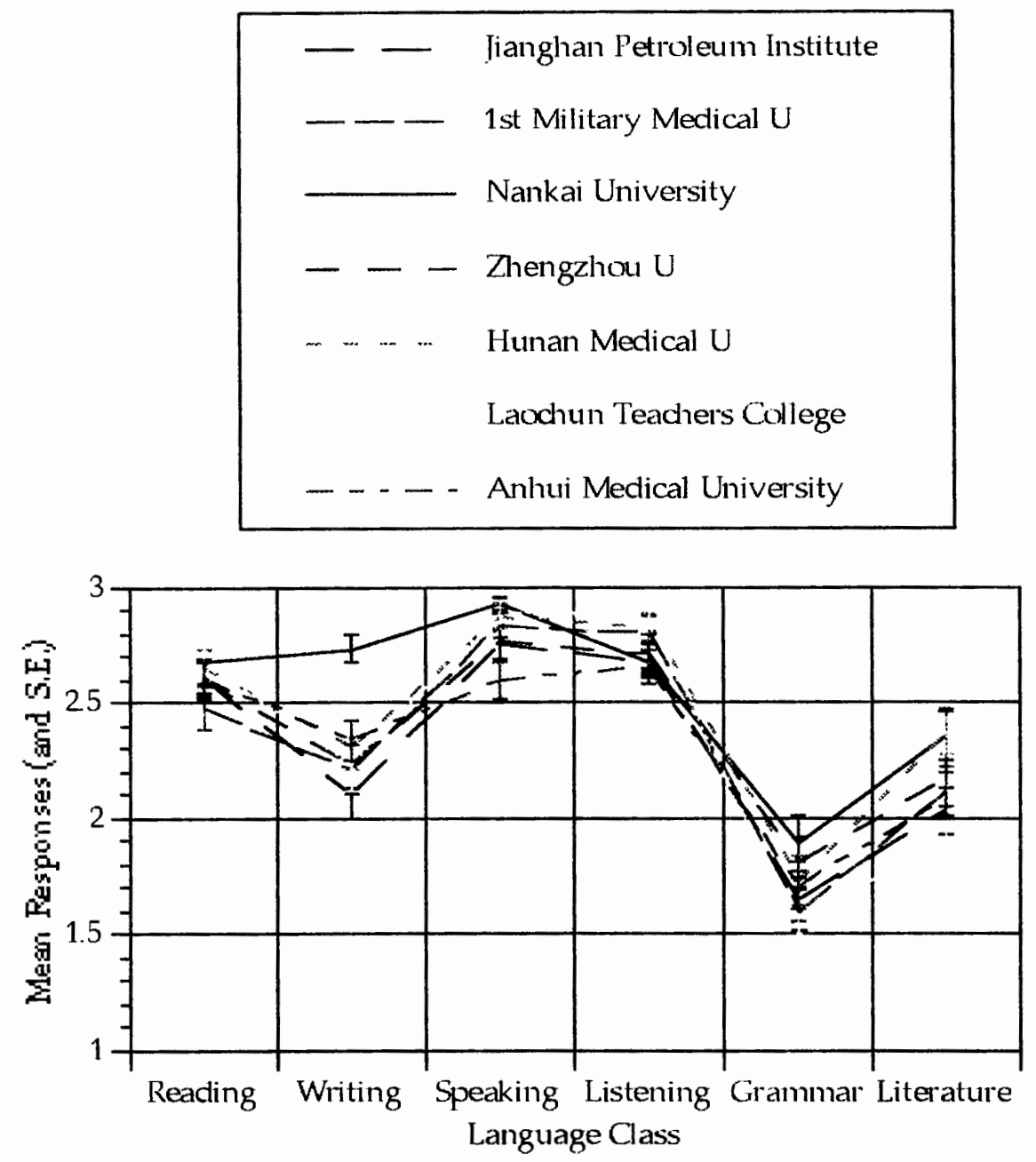

English/Western

Neutral

Chinese

Figure 4. Preferences for teacher and method by school.

\section{The Importance and Use of Language}

The third section of the questionnaire contained 16 two-part questions (25a to $40 \mathrm{~b}$ ) which firstly investigated the importance that respondents attributed to language skills, and to the participants and settings of communication, and secondly allowed respondents to indicate how frequently an item was used. In this discussion, when a questionnaire item is analyzed or discussed in terms of importance, it will have a suffix ' $a$ ', for example, question 25a. Analysis or description of items based on the 
frequency scales will have the suffix ' $b$ ', for example, question $25 b$. The analysis of importance (25a-40a) and use (25b-40b) will be treated separately.

Importance: Figure 5 plots the response profile of teachers against that of students for questions $25 \mathrm{a}$ to $40 \mathrm{a}$. The teachers are responding to statements that read "My student needs to..." whereas the students are responding to statements that read "I need to...". The vertical axis of Figure 5 represents the importance scale used in the questionnaire where $1=$ not important and $5=$ extremely important. Both teachers and students tended towards extremely important, rather than not important for each item.

$$
\begin{aligned}
& - \text { teacher - means } \\
& \text {.-..-- student - means }
\end{aligned}
$$

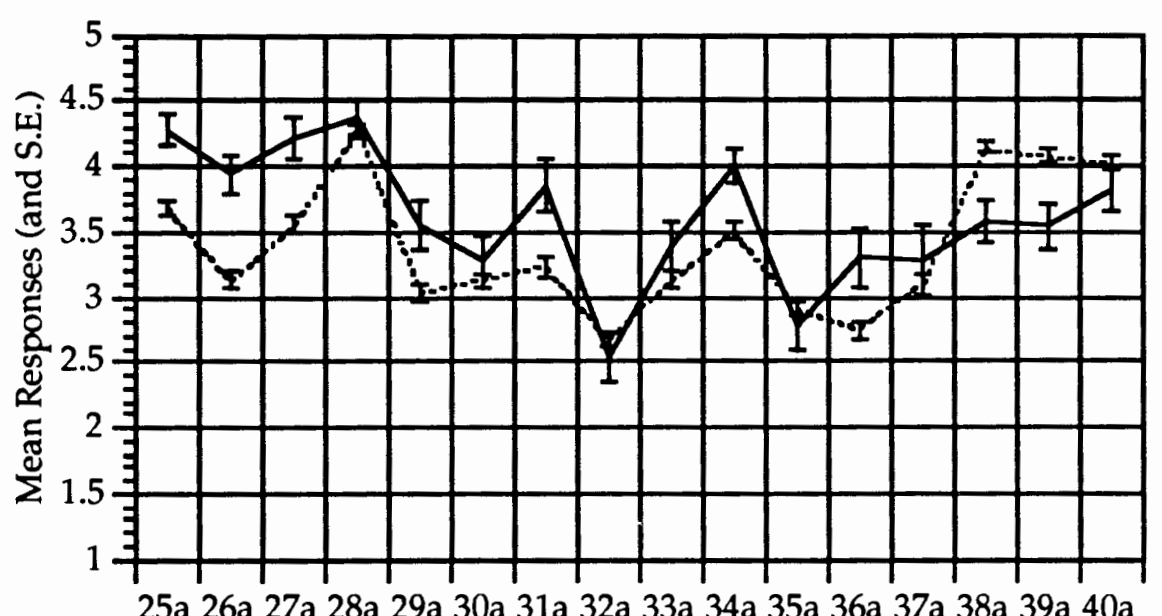

Extremely

Very

Fairly Important

Not very important

Not important

Questions 25-40: Importance

Figure 5. Teachers and students mean responses to questions $25 \mathrm{a}-40 \mathrm{a}$.

In general, the mean student and teacher responses were reasonably correlated $(r=0.6493)$. The questions where students and teachers differed were questions 25a, 26a and 27a where teachers reported that reading, writing and 
speaking skills were more important for their students than students reported. Students reported that English was more important for their private study, education and work than the teachers had anticipated (questions 38a, $39 a$, and $40 a$ respectively).

Frequency: Figure 6 provides traces of the means for the questions related to English usage (questions $25 \mathrm{~b}$ to $40 \mathrm{~b}$ ). The mean of the teachers' responses for this section correlate with the student means at $r=0.846$ : the highest of all four sections of the questionnaire. The vertical axis this time

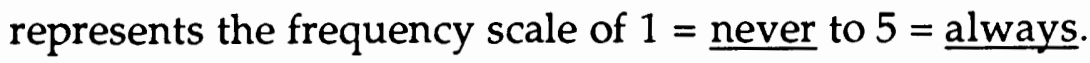
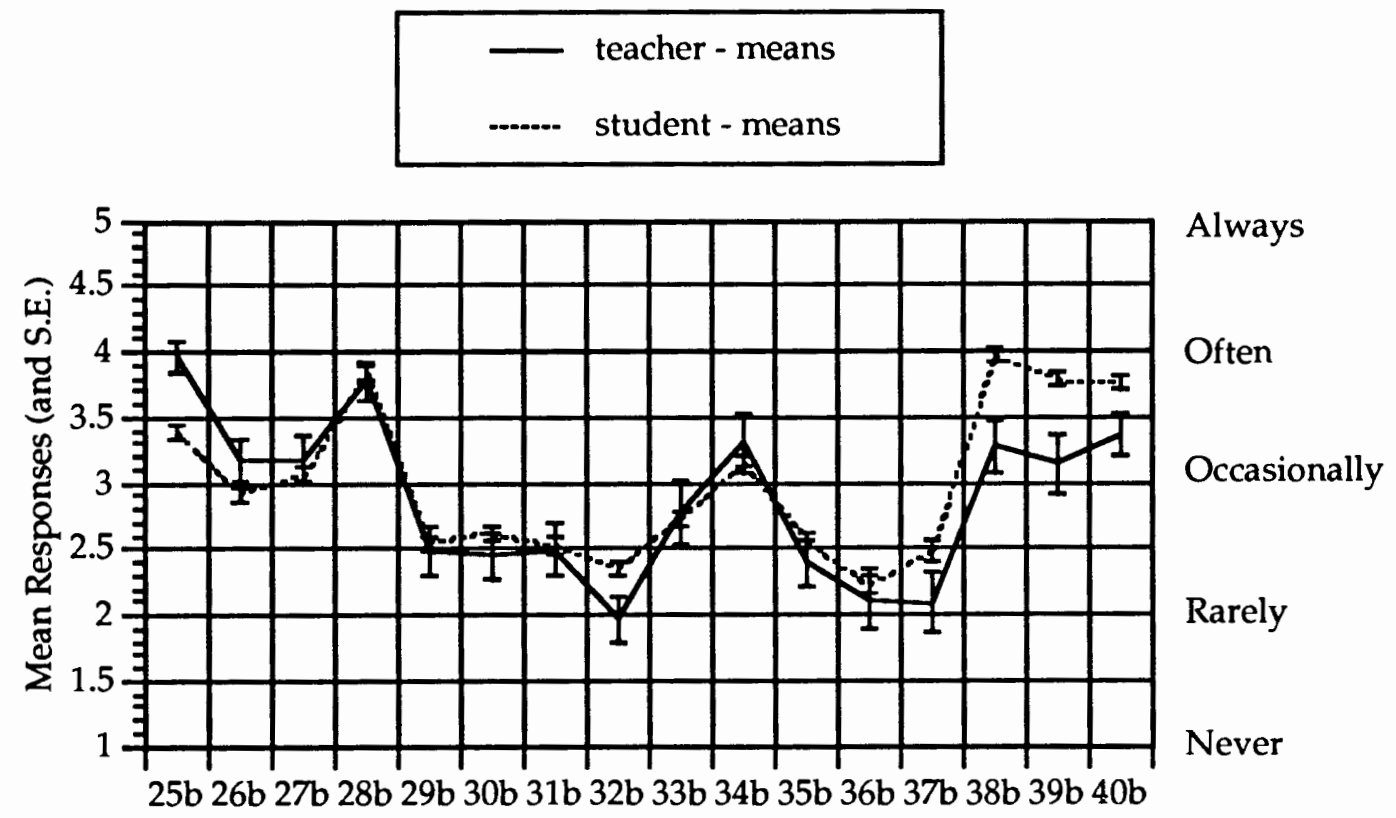

Questions 25-40: Frequency

Figure 6. Teachers and students mean responses to questions $25 \mathrm{~b}-40 \mathrm{~b}$.

Using the descriptive statistics above, listening is ranked the most important language skill (question 28a) by teachers and students and writing the least important. However, whereas teachers perceive students to use reading the most, students again feel that listening is the skill they most need 
to use. Teachers' responses to question $39 \mathrm{~b}$ should be ignored as unfortunately question 38 was repeated (interestingly some slight differences in responses occurred).

The mean response to questions 25 to 40 on both the importance and frequency scale is shown in Figure 7 below. Combined teacher and student responses are plotted as a single line. Figure 7 indicates that items ranked

\section{- Importance - teachers \& students \\ -..-.- Frequency - teachers \& students}

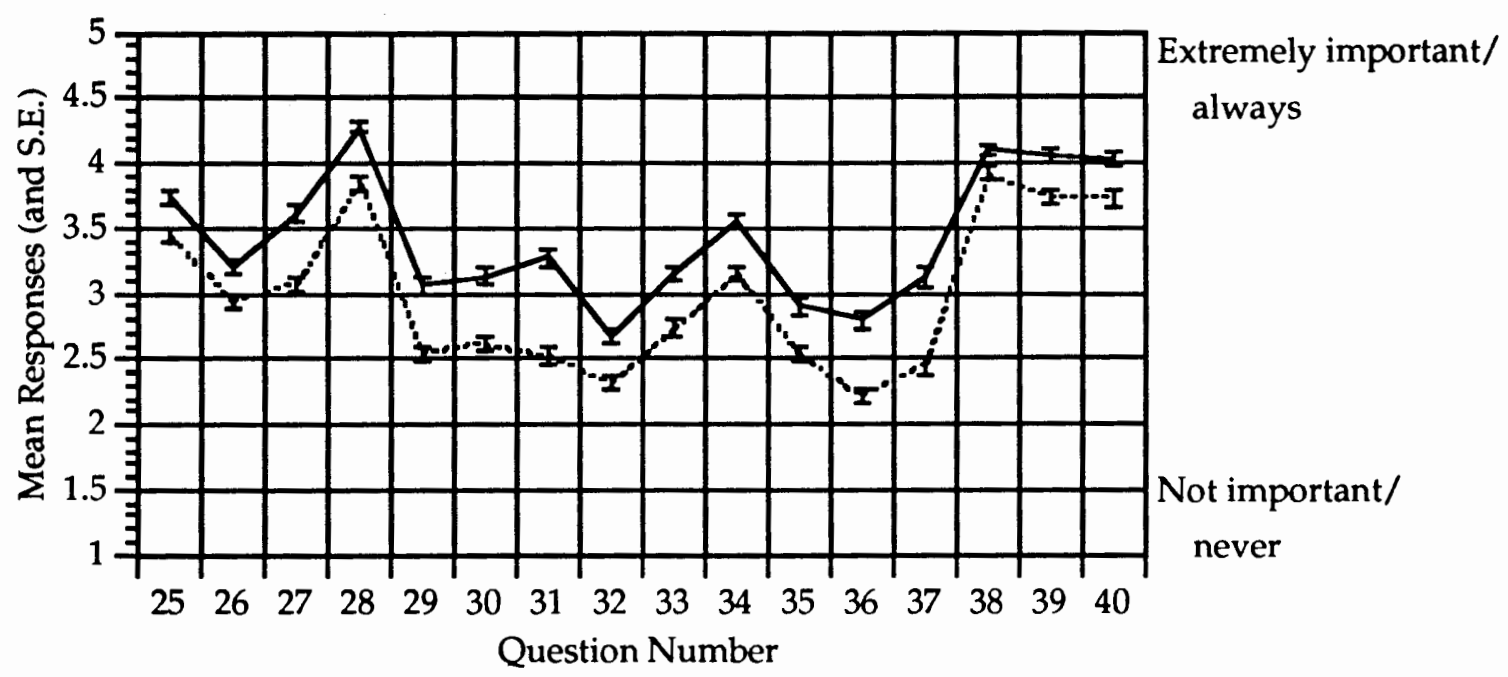

Figure 7. A comparison of the frequency means and importance means from all respondents for questions $25-40$.

high on the frequency scale are also judged important and vice-versa. We cannot compare the absolute values of the two traces. It would be meaningless to say that, for example, Importance $(Q) 31)>$ Frequency $(Q 31)$, for example, because

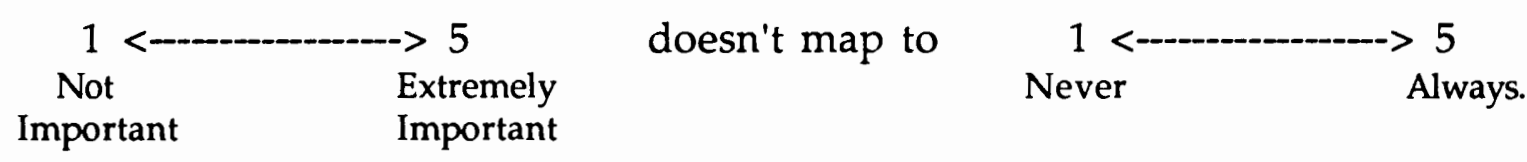


However, we can make assumptions about or at least analyze the relationship of Importance and Frequency. In particular the correlation is a specific assessor of the similarity, beyond just parallelism of the traces. That is, the high correlation between the means of the importance and frequency responses infers that there is an interrelationship between the two scales.

Factor analysis of questions 25 to 40 . Factor analyses were applied to questions $25 a-40 a$ and $25 b-40 b$ separately to examine whether the responses could be summarized by a small number of underlying concepts. Correlations between the items in each group were used to cross-check the validity of the derived factors. Use of a rotated factor analysis yielded four factors. Items were judged to be part of a factor if they passed three criteria: (i) that they had an eligible loading on the rotated factor matrix $(>0.35)$, (ii) that they had an acceptable correlation with other items in the factor group (generally $r>0.4$ ), and (iii) that it was meaningful to group the item with the other items in the factor.

Factors for items 25 to 40 on the importance scale and their interpretation are presented in Table IX.

\section{TABLE IX}

FACTORS FOR QUESTIONS 25A-40A: IMPORTANCE SCALE

\begin{tabular}{|l||l|l|}
\hline Factor: & Items: & Interpretation: \\
\hline \hline Factor 1 & $29 \mathrm{a}, 30 \mathrm{a}, 31 \mathrm{a}, 32 \mathrm{a}, 35 \mathrm{a}, 36 \mathrm{a},(37 \mathrm{a})$ & Audience \\
\hline Factor 2 & $25 \mathrm{a}, 26 \mathrm{a}, 27 \mathrm{a}, 28 \mathrm{a}$ & Skills \\
\hline Factor 3 & $38 \mathrm{a}, 39 \mathrm{a}, 40 \mathrm{a}$ & Tasks \\
\hline Factor 4 & $33 \mathrm{a}, 34 \mathrm{a}$ & $\begin{array}{l}\text { Information exchange } \\
\text { (exchange) }\end{array}$ \\
\hline
\end{tabular}


The correlations and factor loadings of the items in each of the above factors were examined. The items in Factor 1 correlated at 0.34-0.76 and had factor loadings of $0.60-0.77$. Question 37a (I need English to travel outside of China) correlated with other items in Factor 1 at $0.34-0.44$. Because these were so weak, item $37 \mathrm{a}$ has been left out of the factor analysis. The correlations for Factor 1 thus fall between 0.43 and 0.76 . The items in Factor 2 correlated at 0.37-0.61 and had factor loadings of $0.46-0.73$. Question 25 a correlated with question 28a gave the low score of 0.37 . However it was retained in the analysis for two reasons: conceptually it made sense to keep the language skills together, and correlations of both items with the other language skills were above 0.4, the unofficial cutoff line. The items in Factor 3 correlated at 0.43-0.61 and had factor loadings of 0.64-0.82. The items in Factor 4 correlated at 0.71 and had factor loadings of $0.77-0.82$. Comrey discusses levels of factor loadings and their interpretation. He writes that "loadings in excess of 0.71 (50\% variance) are considered excellent, $0.63(40 \%)$ very good, $0.55(30 \%)$ good, $0.45(20 \%)$ fair, and 0.32 (10\% of variance) poor" (cited in Tabachnick and Fidell, 1983, p. 411). These factors will be used in place of the original data in all further discussion of students' responses on the importance scale.

Rotated factor analysis of student responses on the frequency scale and the teacher responses on both scales were likewise completed. The results of all four groupings can be found in Table $X$. In general, the remaining three sets of factor groupings were not as conceptually clean as that of the students' rankings on the importance scale. Those factors which were especially difficult to define and interpret were Factor 3 from student responses on the frequency scale, Factor 1 from teacher responses on the importance scale, and Factor 1 from teacher responses on the frequency scale. 
TABLE $X$

DERIVED FACTORS FROM STUDENT AND TEACHER RESPONSES FOR QUESTIONS 25-40.

\begin{tabular}{|c|c|c|c|c|c|}
\hline Scale & Factor & Items & Interpretation & $\begin{array}{l}\text { Range of } \\
\text { Factor loadings }\end{array}$ & $\begin{array}{l}\text { Range of } \\
\text { Correlations }\end{array}$ \\
\hline Importance & Factor 1 & $29 a, 30 a, 31 a, 32 a, 35 a, 36 a$ & Audience & $0.60-0.77$ & $0.43-0.76$ \\
\hline \multirow[t]{3}{*}{ for students } & Factor 2 & $25 a, 26 a, 27 a, 28 a$ & Skills & $0.47-0.78$ & $0.37-0.61$ \\
\hline & Factor 3 & $38 \mathrm{a}, 39 \mathrm{a}, 40 \mathrm{a}$ & Tasks & $0.65-0.82$ & $0.43-0.61$ \\
\hline & Factor 4 & $33 a, 34 a$ & Info Exchange & $0.77-0.82$ & 0.71 \\
\hline \multirow[t]{3}{*}{$\begin{array}{l}\text { Frequency } \\
\text { for students }\end{array}$} & Factor 1 & $26 b, 27 b, 29 b, 30 b, 31 b, 32 b$ & $\begin{array}{l}\text { Giving info to } \\
\text { others }\end{array}$ & $0.67-0.79$ & $0.43-0.68$ \\
\hline & Factor 2 & $(25 b), 28 b, 38 b, 39 b, 40 b$ & $\begin{array}{l}\text { Getting info for } \\
\text { tasks }\end{array}$ & $(0.39)-0.83$ & $(0.26)-0.67$ \\
\hline & Factor 3 & $33 b, 34 b, 35 b, 36 b$ & $\begin{array}{l}\text { give/receive \& } \\
\text { in/out of China }\end{array}$ & $0.62-0.77$ & $0.43-0.63$ \\
\hline \multirow[t]{4}{*}{$\begin{array}{l}\text { Importance } \\
\text { for teachers }\end{array}$} & Factor 1 & $\begin{array}{l}26 a, 27 a, 28 a, 29 a, 30 a, 31 a, \\
32 a\end{array}$ & Who and how & $0.54-0.92$ & $0.35-0.79$ \\
\hline & Factor 2 & $25 a, 33 a, 34 a, 35 a, 40 a$ & $\begin{array}{l}\text { Communication } \\
\text { inside China }\end{array}$ & $0.49-0.75$ & $0.19-0.66$ \\
\hline & Factor 3 & $38 \mathrm{a}$ & Private study & 0.94 & $\mathrm{n} / \mathrm{a}$ \\
\hline & Factor 4 & $36 a, 37 a$ & $\begin{array}{l}\text { Communication } \\
\text { outside China }\end{array}$ & $0.86-0.88$ & 0.73 \\
\hline \multirow[t]{3}{*}{$\begin{array}{l}\text { Frequency } \\
\text { for teachers }\end{array}$} & Factor 1 & $\begin{array}{l}26 \mathrm{~b}, 27 \mathrm{~b}, 28 \mathrm{~b}, 29 \mathrm{~b}, 30 \mathrm{~b}, 31 \mathrm{~b}, \\
32 \mathrm{~b}, 33 \mathrm{~b}, 34 \mathrm{~b}\end{array}$ & $\begin{array}{l}\text { Who, how \& } \\
\text { direction }\end{array}$ & $0.60-0.88$ & $0.34-0.85$ \\
\hline & Factor 2 & $35 \mathrm{~b}, 36 \mathrm{~b}, 37 \mathrm{~b}, 38 \mathrm{~b}, 40 \mathrm{~b}$ & Place & $0.50-0.83$ & $0.38-0.73$ \\
\hline & Factor 3 & $25 \mathrm{~b}$ & Reading & 0.83 & $\mathrm{n} / \mathrm{a}$ \\
\hline
\end{tabular}

There are some noteworthy features between these groups. For both students and teachers, responses to the importance scale yielded different factors than responses on the frequency scale. Some items remained together for all four sets of responses (for example 29,30,31, and 32; and 33 and 34). In two instances, single items made up a factor in the teacher data. Question 37a: "My students need English to travel" was a factor in teacher importance and question 25b "My students need to read English texts" was a factor in teacher frequency. The emergence of question $25 \mathrm{~b}$ is a particularly interesting case. In the student responses, question 25 had also stood out by bordering on two factors. This indicates that reading is seen in a different way from other 
language skills and confirms to some degree the findings of the literature review that reading is given an elevated role in the process of language learning in China.

For the remaining discussion of questions $25-40$, the factors that emerged from students' responses to the importance scale (audience, skills, tasks and information exchange) will be used to summarize the data. These factors have been chosen because they provide the clearest conceptual groupings for questions $25-40$, and they are derived from a large sample size $(\mathrm{N}=347)$.

Using the factors called audience, skills, tasks and information exchange, comparisons of the responses of several subject groups to items 2540 were carried out. Oneway ANOVA was used to compare 8 groups of subjects based on age, sex, school, number of foreign languages learned, whether students were studying for an external English proficiency exam or not, how frequently a student would use English to travel, students/teachers and the responses of students to 13-18. Except for the student versus teacher group, only student responses are included in these comparisons. The mean response of each group to the items of a factor is plotted with error bars in section B of Appendix D. In general, each subject group followed the same pattern. That is, when one subject group ranked an item high compared to their other responses, another group tended to rank it comparatively high also and vice versa. This showed, among other things, that the overall mean provides a fairly accurate picture of the total responses.

It is interesting to note which of the subject groups ranked items in the same manner and which groups ranked differently. Students older than 23 ranked every item higher than younger students. Male and Female 
respondents gave an almost identical ranking of each factor. English majors ranked Audience, Skills and Tasks higher but Information Exchange lower than non-English majors on both scales. Those students studying for an external exam ranked every factor, especially the importance of audience, higher than students not studying for an external exam. Students more likely to go overseas (as indicated by question $37 \mathrm{~b}$ ) ranked every factor higher than students not likely to travel. Those students who preferred native English teachers for every subject, ranked every factor higher than other respondents. The two groups that provided the most interesting responses to factors were schools (Figure 8) and students versus teachers (Figure 9). The three schools which gave the highest rankings were Nankai university, Laochun teachers college and Zhengzhou University. Nankai and Zhengzhou are those universities which had graduate students respond to the questionnaire. The students at Laochun are all teacher trainees. The school which ranked factors consistently lowest, (Anhui Medical University) had been described by the coordinator as having little need for English except during their training. It would appear that the importance of using English and the degree to which English is used, increase with further training and when learners have a target situation of use in mind while studying. 

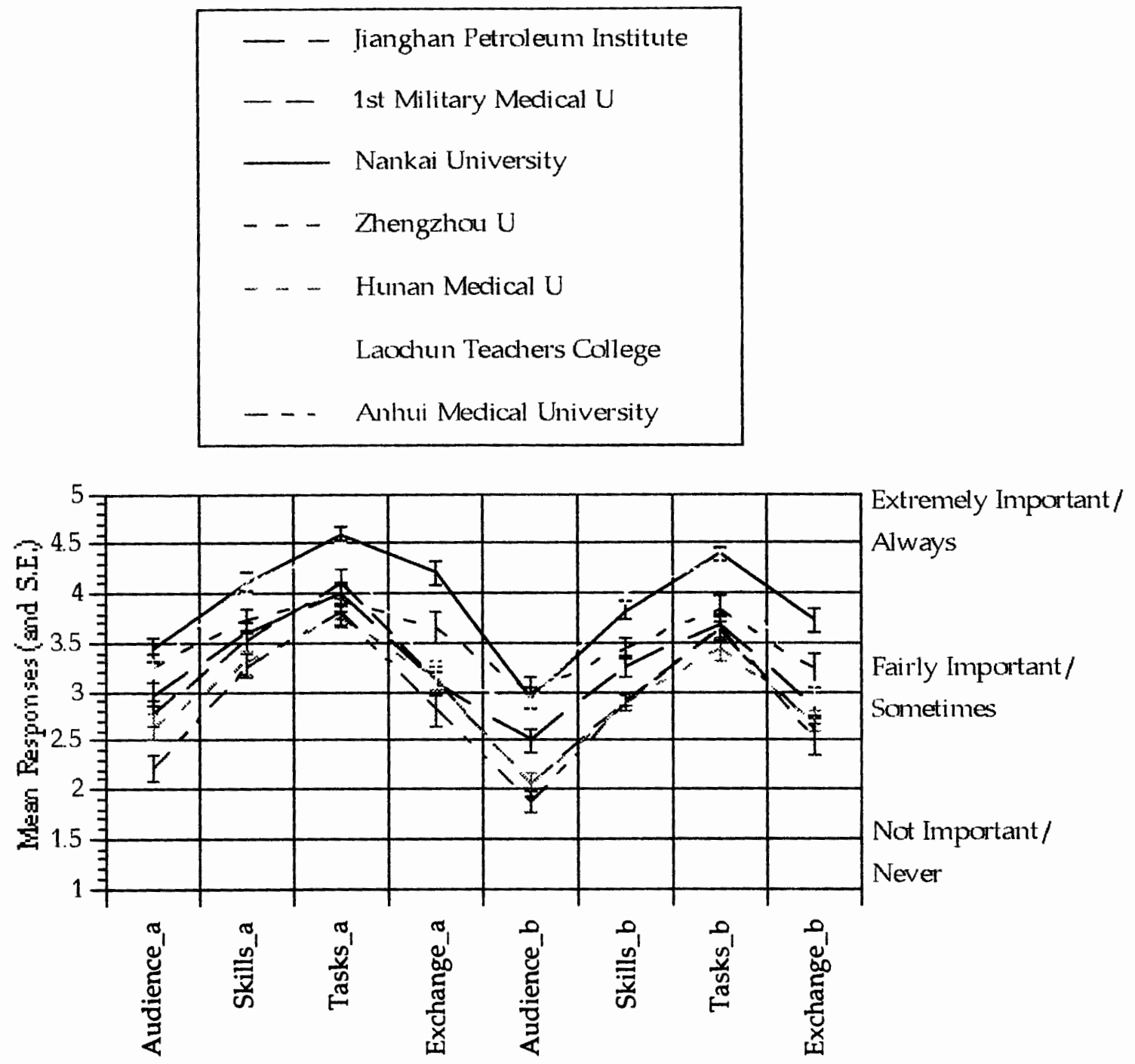

Factor groups for Importance and Frequency

Figure 8. Mean responses to questions 25-40 factor groupings by school.

Teachers and students responded very differently to several factors, as can be seen in Figure 9. Teachers ranked Language Skills as the most important for their students, and Information-Exchange second. Students disagreed and ranked the Tasks in which English would be used as most important followed by Language skills: teachers thought of the language areas, students thought of the implementation. 


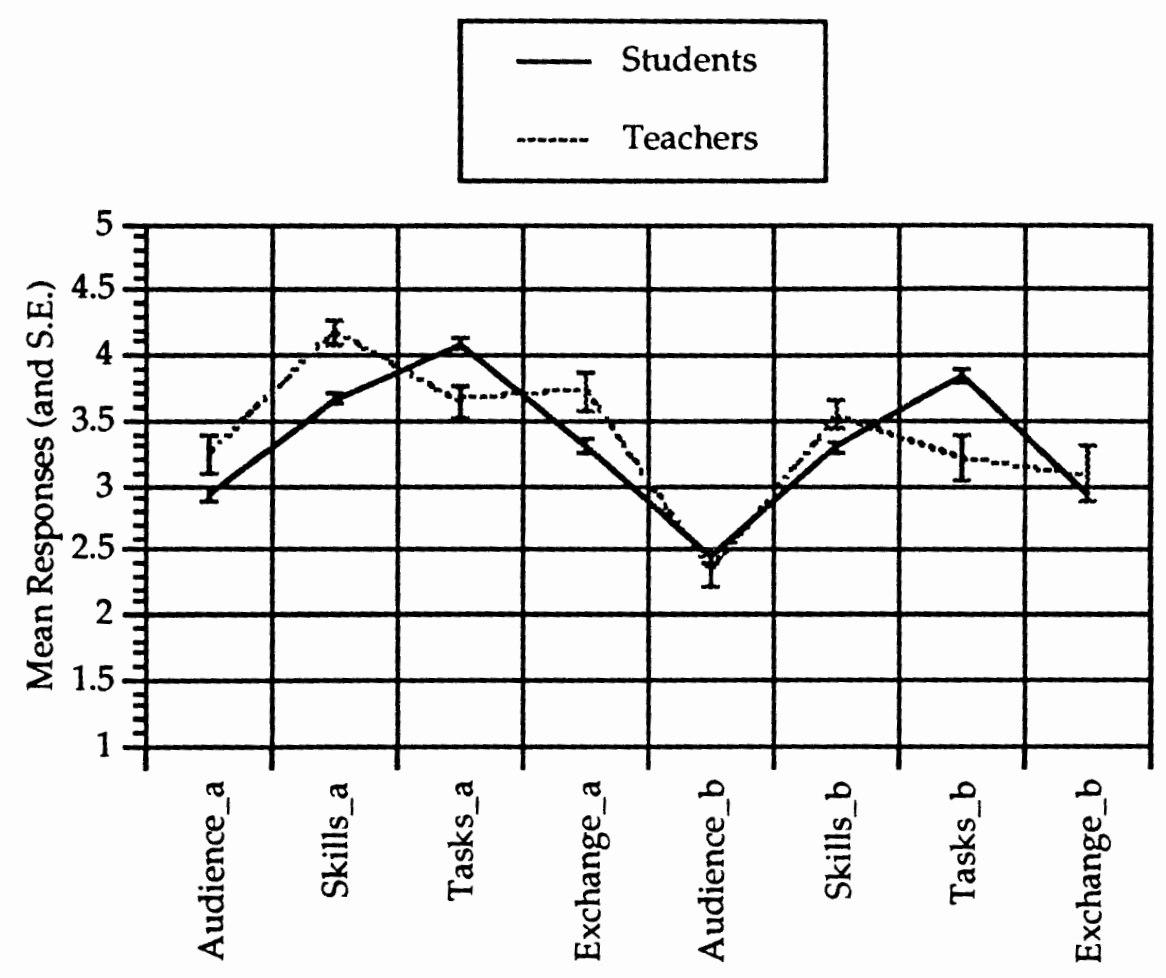

Factor groups for Importance and Frequency

Figure 9. Teachers and students mean responses to the factor groupings of questions 25-40.

Views about Language, Language Learning and Education

The questionnaire items in this section asked respondents about their views towards language, language learning and education. Each item was based on characteristics of Western methodology in order to discover whether or not the set of ideals predominated. Figure 10 outlines the response profile for questions 41-62. The vertical axis represents a 5 point agreement scale that ranges from $1=$ strongly agree to $5=\underline{\text { strongly disagree. }}$ As with questions $25 \mathrm{a}$ $40 \mathrm{a}$, respondents tended to agree rather than disagree with statements.

Teachers provided more variation than did the students. 
- teacher - means

-...-.- student - means

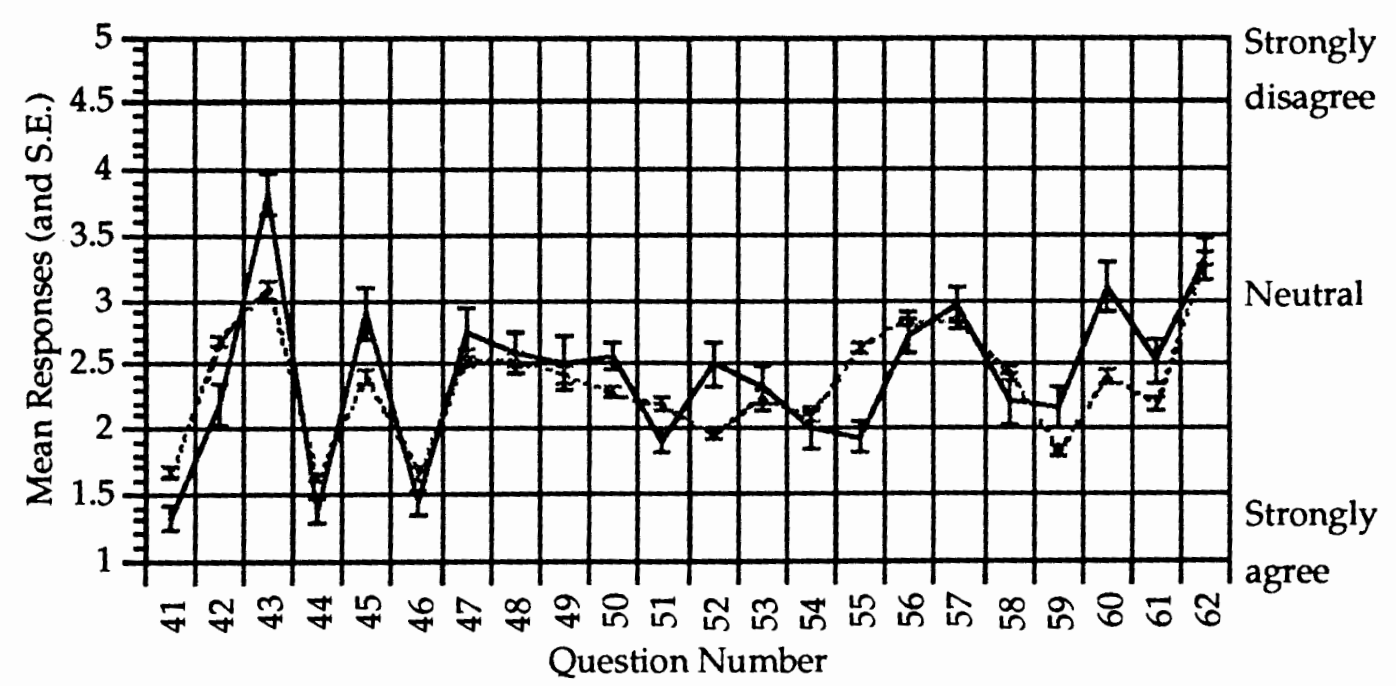

Figure 10. Mean responses of students and teachers for questions 41-62.

Table XI ranks items 41-62 in order from the items most agreed with to the items receiving least agreement, and indicates the associated learning approach.

Factor analysis of questions 41 to 62 . The rank ordering of teachers' responses shown in Table XI suggests strong support for the communicative approach. We can test this supposition by employing the correlation test and factor analysis. Correlations between questions 41-62 for teachers, exhibit no recognizable pattern. On the one hand, questions 41,44 and 46 (language is for communication, involves social and cultural elements, is best learned by use) correlate fairly strongly at $0.58-0.7$, but on the other hand, other seemingly related questions do not correlate. For example questions 43 and 45 ("A language is best learned by separately learning... grammar, phonology and vocabulary" and "The best way to learn a language is to study it") correlate at 
TABLE XI

RANK ORDER OF THE MEANS OF QUESTIONS 41-62 FROM
MOST AGREEMENT TO LEAST AGREEMENT.

\begin{tabular}{|c|c|c|c|c|c|c|c|c|c|c|c|c|}
\hline \multicolumn{4}{|c|}{ MOST } & \multicolumn{6}{|l|}{$<-$} & $\rightarrow$ & \multicolumn{2}{|c|}{ MIDDLE } \\
\hline Teacher & Ithem & 41 & 44 & 46 & 51 & 55 & 54 & 59 & 42 & 58 & 53 & 52 \\
\hline & Approach & $\mathrm{CA}$ & $C A$ & $\begin{array}{l}\mathrm{AL} / \\
\mathrm{CA}\end{array}$ & $\mathrm{CA}$ & $C A$ & $\mathrm{CA}$ & $E D$ & GT & $E D$ & $\mathrm{CA}$ & $-\mathrm{AL}$ \\
\hline Student & them & 44 & 46 & 41 & 59 & 52 & 54 & 51 & 61 & 53 & 50 & 60 \\
\hline & Approach & $\mathrm{CA}$ & $\begin{array}{l}\mathrm{AL/} \\
\mathrm{CA}\end{array}$ & $\mathrm{CA}$ & $E D$ & $-A L$ & $\mathrm{CA}$ & $\mathrm{CA}$ & ED & CA & GT & $\begin{array}{l}\mathrm{GT} / \\
\mathrm{ED}\end{array}$ \\
\hline
\end{tabular}

\begin{tabular}{|c|c|c|c|c|c|c|c|c|c|c|c|c|}
\hline \multicolumn{2}{|c|}{ TABLE XI Cont.. } & \multicolumn{2}{|c|}{ MIDDLE } & \multicolumn{6}{|l|}{$\leq-$} & $\rightarrow$ & \multicolumn{2}{|c|}{ LEAST } \\
\hline Teacher & lhem & 49 & 61 & 50 & 48 & 56 & 47 & 45 & 57 & 60 & 62 & 43 \\
\hline & Approach & $\mathrm{AL}$ & ED & GT & $\mathrm{AL}$ & $\mathrm{AL}$ & $\begin{array}{l}\mathrm{AL} / \\
\mathrm{CA}\end{array}$ & GT & $-G T$ & $\begin{array}{l}\text { GT } \\
\text { ED } \\
\end{array}$ & $E D$ & GT \\
\hline Student & them & 45 & 49 & 58 & 48 & 47 & 55 & 42 & 57 & 56 & 43 & 62 \\
\hline & Approach & KGT & $\mathrm{AL}$ & ED & $\mathrm{AL}$ & $\begin{array}{l}\mathrm{AL} \\
\mathrm{CA}\end{array}$ & CA & GT & $-G T$ & $\mathrm{AL}$ & GT & $E D$ \\
\hline
\end{tabular}

Key: $\mathrm{CA}=$ Communicative, $\mathrm{GT}=$ Grammar Translation, $\mathrm{AL}=$ AudioLingual, $\mathrm{ED}=$ Educational viewpoint. A negative sign (e.g. - $\mathrm{CA}$ ) indicates that the given approach (in this case the Communicative approach) disagrees with the item.

-0.139. Factor analysis of the final section of the questionnaire yields no usable factors. Within the seven potential factors investigated, ten questions were correlated with other members of their factor group at less than 0.4 . If these questions were removed from the factor groups, then only half the variance in the data was accounted for. Moreover, only two of the revised factors contained more than two questions. (Factor $1=42,55,57,59$ and Factor $2=41$, $44,46)$. Because of the large number of factors and low correlations of their members, factors will not be used to describe the teachers' responses.

Correlations within student responses to questions 41-62 are also extremely low. Only four of the correlations are higher than 0.3 . The six 
identified factors are marginally meaningful but together account for only $47 \%$ of the variation in data.

The original purpose of questions 41 to 62 was to look to see which language learning method(s) were most agreed with. The aim was to calculate the mean response to each 'method' using factors: either preconceived factors (by method groupings as shown in Table V, chapter 3), or statistically derived factors. However, the subjects did not seem to construct opinions along these conceptual guidelines. "The fact that the items are not correlated precludes creating a summary index of those items as the summary would be very unreliable... They [each item] are distinct concepts not linked by an underlying concept" (Gaines, private correspondence). The subjects responded to each question independently and not to the concepts underlying the questions.

Conceptual grouping of questions 41 to 62. Given that the respondents did not think of items 41-62 using a conceptual framework, the remaining discussion of the final section of the questionnaire looks at the group responses to each question individually. In order to assist the interpretation of these responses, the data will be organized using a simplified version of the original conceptual framework. It must be stressed that the questions within these groupings tend to have very weak correlations and the groups themselves must not be thought of as supported by the data. Four questions appear in more than one conceptual group. These statements fit equally well in both the approaches. In question 52 for the Audio-Lingual approach, and in question 57 for the Grammar-Translation approach, it is the complement of their score that supports the respective approaches. In these cases, the complemented items are indicated by $52^{\prime}$ and $57^{\prime}$, and the complemented means are calculated by 6 minus the response means, while the standard 
errors remain unchanged.

The four conceptual groups under which questions 41-62 are analyzed are educational views, and the Communicative, Audio-Lingual, and Grammar-Translation approaches. The mean responses of teachers and students are plotted in Figure 11. Figure 11 lists items within a conceptual group in order from the student item that gained the most agreement from students to the item which gained the least agreement (as indicated by the

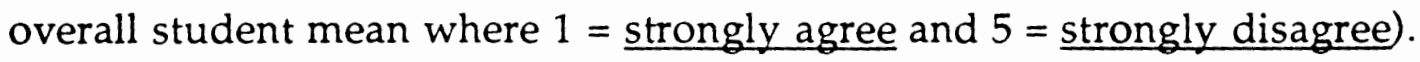

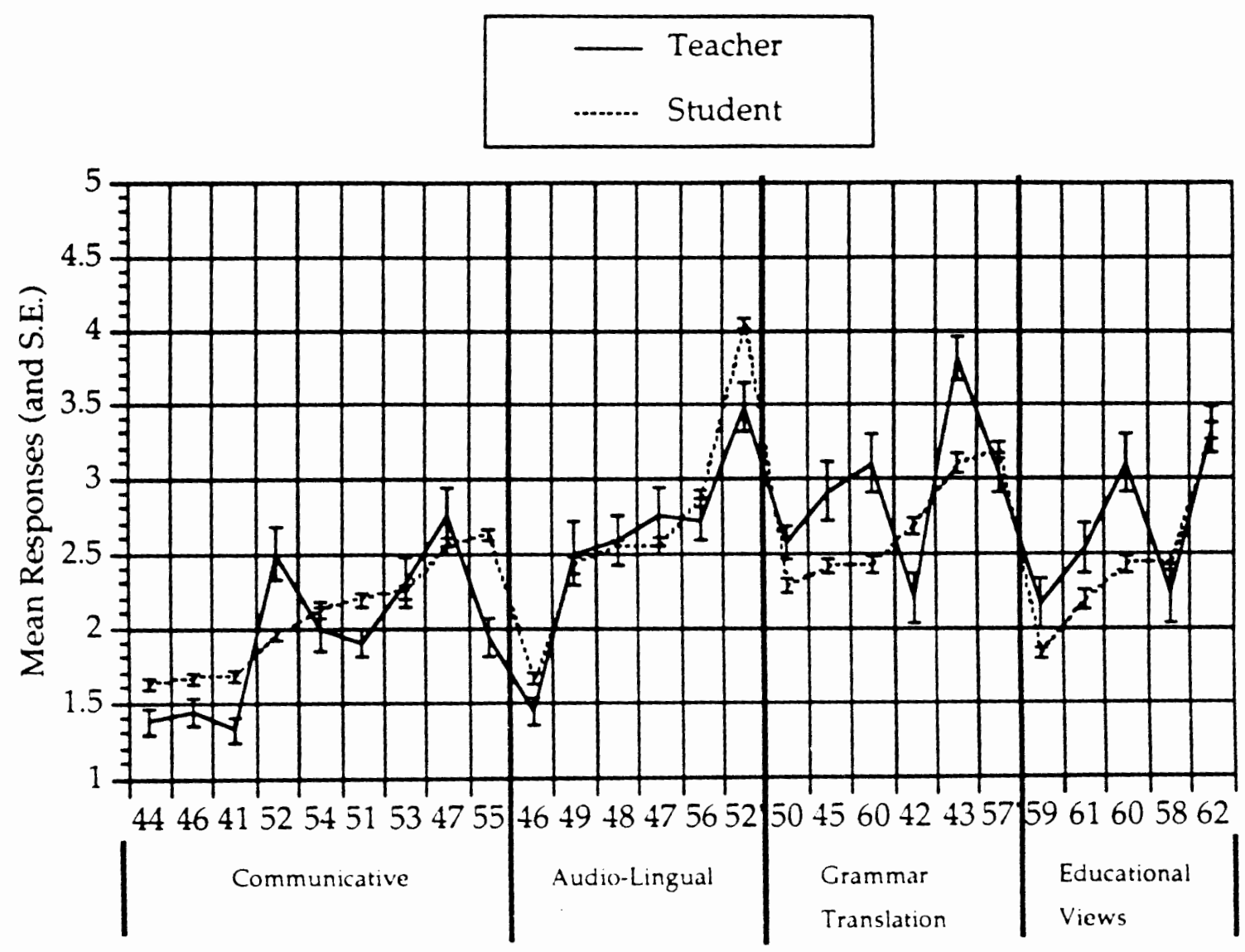

Figure 11. Mean response of teachers and students to questions 41-62 ordered by students' agreement to items within the conceptual groupings. $1=$ Strongly Agree and $5=$ Strongly Disagree. 
The mean response of various respondent groups to the four groups of questions can be found in Table XII. Table XII also orders items using students' level of agreement. An ANOVA was calculated for each of the group, and the probability of rejecting the hypothesis that all groups are drawn from the same population is tabulated as the $p$ value. Only those responses where $p<0.05$ are considered significant.

The first conceptual group is the statements consistent with the communicative approach. An important trend can be noticed in this group of items: as the questions move from ideals to the practical implementation of ideals, the level of affirmation decreases. This is an important finding and will be discussed further in the next chapter.

Mean responses to the items under the audio-lingual approach were in general lower than those to the communicative approach. Again, the ideals are more strongly affirmed than the implementation of the ideals themselves.

Questions under the Grammar-Translation approach received low ratings. It is obvious that students do not agree with question 43 "A language is best learned by separately learning language areas such as grammar, phonology, and vocabulary." However, in general, students were fairly eager to receive clear grammar instruction (question 50). It is interesting to notice that graduate students (the students from Nankai University and Zhengzhou University), and students studying for an external exam both ranked question 45 "The best way to learn a language is to study it" comparatively higher than other students. 
TABLE XII

\section{RESPONSES TO QUESTIONS 41-62 BY CONCEPTUAL FRAMEWORK AND SUBJECT GROUPS}

\begin{tabular}{|c|c|c|c|c|c|c|c|c|c|c|c|c|c|c|c|c|}
\hline \multirow{2}{*}{$\begin{array}{l}\text { Respondant } \\
\text { Groups }\end{array}$} & \multirow[b]{2}{*}{ Items: } & \multicolumn{9}{|c|}{ Communicative Approach } & \multicolumn{6}{|c|}{ Audio-Lingual Approach } \\
\hline & & 44 & 46 & 41 & 52 & 54 & 51 & 53 & 47 & 55 & 46 & 49 & 47 & 48 & 56 & $52^{\prime}$ \\
\hline \multicolumn{2}{|l|}{ Students } & 1.61 & 1.64 & 1.67 & 1.96 & 2.09 & 2.19 & 2.21 & 2.56 & 2.63 & 1.64 & 2.45 & 2.56 & 2.56 & 2.88 & 4.04 \\
\hline \multicolumn{2}{|l|}{ Teachers } & 1.41 & 1.48 & 1.34 & 2.55 & 1.97 & 1.97 & 2.38 & 2.76 & 1.93 & 1.48 & 2.55 & 2.76 & 2.69 & 2.76 & 3,45 \\
\hline \multirow[t]{8}{*}{ Schools-Stu } & Jianghan & 1.56 & 1.86 & 1.88 & 1.96 & 2.24 & 1.96 & 2.22 & 2.94 & 2.56 & 1.86 & 2.42 & 2.94 & 2.65 & 2.88 & 4.04 \\
\hline & 1st military & 1.50 & 1.51 & 1.44 & 1.88 & 2.37 & 2.08 & 2.24 & 2.70 & 2.90 & 1.51 & 2.48 & 2.70 & 2.44 & 2.98 & 4.12 \\
\hline & Nankai & 1.67 & 1.49 & 1.70 & 1.96 & 1.83 & 2.27 & 2.24 & 1.93 & 2.36 & 1.49 & 2.36 & 1.93 & 2.63 & 2.78 & 4.04 \\
\hline & Zhengzhou & 1.96 & 1.83 & 1.92 & 2.20 & 2.35 & 2.52 & 2.41 & 2.33 & 2.49 & 1.83 & 2.14 & 2.33 & 2.48 & 2.59 & 3.80 \\
\hline & Hunan & 1.64 & 1.50 & 1.58 & 1.90 & 2.04 & 2.10 & 2.46 & 2.54 & 2.80 & 1.50 & 2.50 & 2.54 & 2.44 & 2.82 & 4.10 \\
\hline & Laochun & 1.52 & 1.52 & 1.58 & 1.76 & 1.74 & 2.22 & 2.04 & 2.44 & 2.20 & 1.52 & 2.44 & 2.44 & 2.72 & 2.98 & 4.24 \\
\hline & Anhui & 1.54 & 1.89 & 1.62 & 2.00 & 2.27 & .2 .22 & 2.10 & 2.92 & 3.04 & 1.89 & 2.58 & 2.92 & 2.44 & 3.04 & 4.00 \\
\hline & Probability & 0.005 & 0.01 & 0.01 & 0.07 & 0.006 & 0.07 & 0.15 & 0.0000 & 0.0000 & 0.01 & 0.53 & 0.0000 & 0.52 & 0.28 & 0.07 \\
\hline \multirow[t]{5}{*}{ Age } & 1st quartile & 1.51 & 1.73 & 1.59 & 1.96 & 2.23 & 2.02 & 2.21 & 2.82 & 2.75 & 1.73 & 2.58 & 2.82 & 2.57 & 2.94 & 4.04 \\
\hline & 2nd & 1.55 & 1.58 & 1.70 & 1.86 & 2.09 & 2.13 & 2.36 & 2.69 & 2.72 & 1.58 & 2.38 & 2.69 & 2.53 & 2.82 & 4.14 \\
\hline & $3 \mathrm{rd}$ & 1.70 & 1.66 & 1.72 & 1.92 & 2.08 & 2.34 & 2.08 & 2.49 & 2.56 & 1.66 & 2.37 & 2.49 & 2,51 & 2.93 & 4.08 \\
\hline & 4 th & 1.78 & 1.63 & 1.70 & 2.06 & 2.04 & 2.33 & 2.36 & 2.12 & 2.43 & 1.63 & 2.29 & 2.12 & 2.55 & 2.75 & 3.94 \\
\hline & Probability & $p>0.02$ & 0.64 & $p<0.61$ & 0.28 & 0.61 & 0.04 & 0.10 & 0.0002 & 0.05 & 0.64 & 0.27 & 0.0002 & 0.98 & 0.52 & 0.28 \\
\hline \multirow{3}{*}{$\begin{array}{l}\text { External } \\
\text { exam }\end{array}$} & Yes & 1.61 & 1.52 & 1.55 & 1.82 & 2.00 & 2.16 & 2.18 & 2.18 & 2.46 & 1.52 & 2.22 & 2.18 & 2.63 & 2.76 & 4.18 \\
\hline & No & 1.63 & 1.68 & 1.70 & 1.98 & 2.15 & 2.19 & 2.26 & 2.80 & 2.64 & 1.68 & 2.45 & 2.80 & 2.53 & 2.90 & 4.02 \\
\hline & Probability & 0.81 & 0.21 & 0.20 & 0.14 & 0.34 & 0.85 & 0.52 & 0.01 & 0.15 & 0.21 & 0.15 & 0.01 & 0.47 & 0.37 & 0.14 \\
\hline \multirow{3}{*}{$\begin{array}{l}\text { English } \\
\text { Major }\end{array}$} & Yes & 1.53 & 1.53 & 1.56 & 1.83 & 1.83 & 2.12 & 2.15 & 2.42 & 2.19 & 1.53 & 2.32 & 2.42 & 2.66 & 2.93 & 4.17 \\
\hline & No & 1.65 & 1.68 & 1.70 & 1.98 & 2.18 & 2.21 & 2.27 & 2.57 & 2.71 & 1.68 & 2.43 & 2.57 & 2.52 & 2.86 & 4.02 \\
\hline & Probability & 0.18 & 0.18 & 0.20 & 0.0 .13 & 0.016 & 0.51 & 0.34 & 0.36 & 0.0000 & 0.18 & 0.47 & 0.36 & 0.27 & 0.59 & 0.0 .13 \\
\hline \multirow{3}{*}{$\begin{array}{l}\text { \# FL besides } \\
\text { English }\end{array}$} & 0 & 1.64 & 1.69 & 1.70 & 2.01 & 2.22 & 2.18 & 2.26 & 2.67 & 2.73 & 1.69 & 2.48 & 2.67 & 2.55 & 2.87 & 3.99 \\
\hline & 1 & 1.56 & 1.54 & 1.59 & 1.75 & 1.77 & 2.22 & 2.20 & 2.12 & 2.22 & 1.54 & 2.20 & 2.12 & 2.52 & 2.84 & 4.25 \\
\hline & Probability & 0.31 & 0.16 & 0.26 & 0.0033 & 0.0009 & 0.76 & 0.61 & 0.0001 & 0.0000 & 0.16 & 0.65 & 0.0001 & 0.81 & 0.77 & 0.0033 \\
\hline \multirow[t]{3}{*}{ NS teacher } & Yes & 1.59 & 1.53 & 1.63 & 1.90 & 1.90 & 2.15 & 2.18 & 2.29 & 2.33 & 1.53 & 2.43 & 2.29 & 2.67 & 2.77 & 4.10 \\
\hline & No & 1.65 & 1.73 & 1.70 & 1.99 & 2.27 & 2.22 & 2.29 & 2.70 & 2.81 & 1.73 & 2.40 & 2.70 & 2.46 & 2.93 & 4.01 \\
\hline & Probability & 0.41 & 0.03 & 0.37 & 0.28 & 0.0014 & 0.52 & 0.21 & 0.0008 & 0.0000 & 0.03 & 0.84 & 0.0008 & 0.03 & 0.13 & 0.28 \\
\hline
\end{tabular}


TABLE XII Continued

RESPONSES TO QUESTIONS 41-62 BY CONCEPTUAL FRAMEWORK AND SUBJECT GROUPS

\begin{tabular}{|c|c|c|c|c|c|c|c|c|c|c|c|c|c|}
\hline \multirow{2}{*}{$\begin{array}{l}\text { Respondant } \\
\text { Groups }\end{array}$} & \multirow[b]{2}{*}{ Items: } & \multicolumn{4}{|c|}{ Grammar-Translation } & \multicolumn{2}{|c|}{ Approach } & \multicolumn{5}{|c|}{ Education Views } & \multirow{2}{*}{$\begin{array}{l}\text { Number } \\
(\mathrm{n}=\mathrm{X})\end{array}$} \\
\hline & & 50 & 45 & 60 & 42 & 43 & 57 & 59 & 61 & 58 & 60 & 62 & \\
\hline \multicolumn{2}{|l|}{ Students } & 2.27 & 2.42 & 2.44 & 2.67 & 3.10 & 3.17 & 1.85 & 2.18 & 2.44 & 2.44 & 3.33 & 347 \\
\hline \multicolumn{2}{|l|}{ Teachers } & 2.59 & 2.83 & 3.00 & 2.21 & 3.86 & 3.10 & 2.17 & 2.44 & 2.31 & 3.00 & 3.24 & 34 \\
\hline \multirow[t]{8}{*}{ Schools } & Jianghan & 2.26 & 2.82 & 2.78 & 2.80 & 3.20 & 3.16 & 1.94 & 2.31 & 2.60 & 2.78 & 3.56 & 50 \\
\hline & 1st military & 2.39 & 2.52 & 2.46 & 2.62 & 3.00 & 3.08 & 1.78 & 2.28 & 2.36 & 2.46 & 3.54 & 50 \\
\hline & Nankai & 2.33 & 2.02 & 2.17 & 2.72 & 2.83 & 3.37 & 1.76 & 1.85 & 2.24 & 2.17 & 3.24 & 46 \\
\hline & Zhengzhou & 2.17 & 1.97 & 2.24 & 2.46 & 2.83 & 3.29 & 1.94 & 2.12 & 2.38 & 2.24 & 2.94 & 49 \\
\hline & Hunan & 2.36 & 2.30 & 2.14 & 2.82 & 3.26 & 3.32 & 1.82 & 2.38 & 2.48 & 2.14 & 3.34 & 50 \\
\hline & Laochun & 2.20 & 2.70 & 2.92 & 2.70 & 3.54 & 2.88 & 1.72 & 2.14 & 2.58 & 2.92 & 3.36 & 50 \\
\hline & Anhui & 2.22 & 2.46 & 2.14 & 2.66 & 2.94 & 3.20 & 1.85 & 2.20 & 2.38 & 2.14 & 3.16 & 50 \\
\hline & Probability & 0.78 & 0.0000 & 0.0000 & 0.59 & 0.02 & 0.12 & 0.72 & 0.27 & 0.66 & 0.0000 & 0.07 & $n / a$ \\
\hline \multirow[t]{5}{*}{ Age } & 1st quartile & 2.25 & 2.48 & 2.43 & 2.78 & 3.13 & 3.17 & 1.83 & 2.36 & 2.37 & 2.43 & 3.39 & 105 \\
\hline & 2nd & 2.34 & 2.64 & 2.38 & 2.60 & 3.21 & 3.13 & 1.88 & 2.22 & 2.65 & 2.38 & 3.40 & 77 \\
\hline & $3 r d$ & 2.21 & 2.43 & 2.52 & 2.66 & 3.00 & 3.15 & 1.79 & 2.12 & 2.34 & 2.52 & 3.22 & 86 \\
\hline & 4th & 2.32 & 2.05 & 2.30 & 2.66 & 3.00 & 3.29 & 1.81 & 2.00 & 2.41 & 2.30 & 3.19 & 72 \\
\hline & Probability & 0.70 & 0.001 & 0.54 & 0.62 & 0.60 & 0.71 & 0.89 & 0.14 & 0.25 & 0.54 & 0.47 & $\mathrm{n} / \mathrm{a}$ \\
\hline \multirow{3}{*}{$\begin{array}{l}\text { External } \\
\text { exam }\end{array}$} & Yes & 2.39 & 2.10 & 1.88 & 2.35 & 3.41 & 3.31 & 1.78 & 1.82 & 2.16 & 1.88 & 3.14 & 51 \\
\hline & No & 2.26 & 2.45 & 2.51 & 2.73 & 3.04 & 3.15 & 1.84 & 2.25 & 2.49 & 2.51 & 3.33 & 291 \\
\hline & Probability & 0.28 & 0.02 & 0.0000 & 0.009 & 0.03 & 0.23 & 0.57 & 0.0086 & 0.05 & 0.0000 & 0.24 & $n / a$ \\
\hline \multirow{3}{*}{$\begin{array}{l}\text { English } \\
\text { Major }\end{array}$} & Yes & 2.10 & 2.68 & 2.93 & 2.68 & 3.53 & 2.97 & 1.64 & 2.19 & 2.62 & 2.93 & 3.41 & 59 \\
\hline & No & 2.31 & 2.35 & 2.30 & 2.68 & 3.00 & 3.22 & 1.86 & 2.19 & 2.40 & 2.30 & 3.28 & 285 \\
\hline & Probability & 0.072 & 0.02 & 0.0000 & 0.97 & 0.0014 & 0.046 & 0.044 & 0.98 & 0.16 & 0.0000 & 0.42 & $n / a$ \\
\hline \multirow{3}{*}{$\begin{array}{l}\text { \# FL besides } \\
\text { English }\end{array}$} & 0 & 2.28 & 2.44 & 2.41 & 2.68 & 3.05 & 3.19 & 1.90 & 2.30 & 2.52 & 2.41 & 3.31 & 272 \\
\hline & 1 & 2.27 & 2.67 & 2.44 & 2.69 & 3.24 & 3.15 & 1.56 & 1.76 & 2.11 & 2.44 & 3.25 & 76 \\
\hline & Probability & 0.46 & 0.15 & 0.79 & 0.92 & 0.20 & 0.69 & 0.0007 & 0.0001 & 0.0033 & 0.79 & 0.63 & $n / a$ \\
\hline \multirow[t]{3}{*}{ NS teacher } & Yes & 2.23 & 2.43 & 2.59 & 2.75 & 3.21 & 3.17 & 1.80 & 2.12 & 2.48 & 2.59 & 3.23 & 135 \\
\hline & No & 2.30 & 2.39 & 2.29 & 2.64 & 3.02 & 3.19 & 1.84 & 2.22 & 2.41 & 2.29 & 3.29 & 208 \\
\hline & Probability & 0.42 & 0.69 & 0.0062 & 0.31 & 0.14 & 0.90 & 0.68 & 0.41 & 0.59 & 0.0062 & 0.75 & $\mathrm{n} / \mathrm{a}$ \\
\hline
\end{tabular}


Mean responses to the educational views (questions 58-62), show very little variation between schools except for question 60 "education occurs primarily through intensive reading." It is difficult to say anything about Chinese educational views from these questions as they are very biased towards Western views. Question 62 (The aim of education is to get a good job) received very little support. It is possible that if question 62 was worded: "The aim of education is to be prepared to do a good job" it may have gained a different response. Question 59 (Students should feel free to interrupt the teacher with questions and comments at any time) received the highest overall score of this section.

\section{SUMMARY OF THE DATA}

The statistics gained were analyzed for points of convergence in opinion regarding views of language, language learning and education and in terms of intended usage of English. When analysis of the data yielded factors which were statistically valid and conceptually meaningful, these factors were used instead of the original questionnaire items to summarize group responses. Where no factors were found, individual questionnaire items were retained as the focus of further analysis and discussion. The following chapter will discuss the implications of this data. 


\section{CHAPTER V \\ DISCUSSION OF RESULTS}

\section{INTRODUCTION}

Chapter IV described the results from the questionnaires. This chapter aims to discuss the data collected, answer the research questions and provide guidelines for curriculum development. Each of the research questions will be restated and discussed in terms of the data collected. Then the data will be summarized in terms of English language curricula for students at Chinese universities.

\section{DISCUSSION OF RESEARCH QUESTIONS}

Research Question 1 (a) What are the views about language prevalent in China among English language learners and teachers in Chinese universities? ia) Do the prevalent views about language lend themselves to the use of a particular methodology? If so, what methodology?

(a) From the literature review it was evident that language and language learning are valued in the P.R.C.. Total literacy in Chinese characters is a national goal. In addition, the government encourages students to learn English to assist modernization. This study reinforced the consensus that language is perceived to be important. Seventy six of the 347 students (32\%) and $65 \%$ of the teachers who participated in this study had learnt a 
foreign language in addition to English. This demonstrates that foreign languages are regarded highly in China.

Teachers and students ranked the four language skills with regard to importance in the same order. Listening was the most important language skill followed by reading, speaking, and writing. Receptive skills (listening and reading) are perceived to be more important than the active skills (speaking and writing).

The students ranked the four skills on the frequency scale in the same order as they did for the importance scale, but teachers believed that students most needed to read texts, then listen. That teachers perceived reading to be the most used skill indicates the focus on reading in foreign language study and use in China: a focus continually emphasized in the literature review (see Huang and Van Naerssen, 1987, and others). Both teachers and students again ranked the passive skills higher than active skills. This could indicate that Chinese students rarely need to convey information using English, or that students prefer not to use active skills. This in turn may indicate that students dislike revealing their language learning strengths and weaknesses in public. Respondents' preference for passive skills was noted in the literature review by Ye and $\mathrm{Li}(1988)$.

An examination of different groups of student respondents yielded the same rank order given to the four language skills as the complete student and teacher groups but with different levels of importance or frequency. Older students and graduate students ranked all the four skills as more important and used the skills more frequently.

The views about languages held by students and teachers, as shown by questions $41-44$, are those held by the communicative approach, namely that 
the purpose of language is communication (question 41) and that language involves social and cultural elements (question 44). The language views which undergird the Grammar-Translation approach (namely that languages are rule-based and best learnt by separately learning phonology, grammar and vocabulary) were not supported as strongly. In general, the literature review implied the predominance of language concepts that agreed with the Grammar-Translation approach (see Maley, 1986). This was not borne out in the response to questions 41-44 of the questionnaire. Instead, the comments made by Moffett (1983) (that students believed that the purpose of language learning was communication) were confirmed.

(b) In practice, these language views yield conflicting results. Agreement with questions 41 and 44 would suggest favoring the Communicative approach. However, students' and teachers' responses to questions 25-28 (language skills) displayed clearly that passive skills were clearly preferred over active skills. The Communicative approach emphasizes the equal importance of all four skills and engages students in active participation in class lessons. More traditional approaches such as the Grammar-Translation approach, give greater emphasis to the passive skills. While the point of emphasis of an approach does not guarantee students who are strong in that language area, the emphasis reflects the language views and goals of the teacher. There appears to be a difference between teachers' and students' views about language and their actual use of language. Authors in the literature review also stated students' lean towards passive skills but tended not to indicate what students' beliefs about language were. Research Question 2 (a) What are the views about language learning prevalent in China among English language learners and teachers in Chinese 
universities? (b) Do the prevalent views about language learning lend themselves to the use of a particular methodology? If so, which methodology?

(a) Two sections of the questionnaire examined the second research question: questions 13-24 and 45-57. Questions 13-24 asked respondents whether they preferred native English teachers or native Chinese speakers and Chinese methods of teaching or Western methods of teaching for various language courses. Respondents tended to link the teacher of a class with the method used to teach that course. Students preferred Native English speakers who used Western methods of teaching to teach reading, writing, speaking and listening classes. Chinese teachers who used Chinese teaching methods were preferred to teach grammar classes. Students remained neutral about the teacher of literature. Teachers agreed with students' preferences, with the exception of reading classes where teachers leaned toward Chinese teachers but Western teaching methods. This was the only case that the teacher of a class and the method used to teach it were not linked. Again it is reading which teachers and students are divided over. Grabe and Mahon (1982) were cited in the literature review as suggesting that Chinese language learning methodology was reading (p. 51). It is difficult to draw that strong a conclusion from these questions, but reading certainly appears to be considered a 'special case' by Chinese teachers of English.

Questions 45-57 dealt more with specific methods of teaching and learning English. These questions attempted to gauge which methods were most favored by the respondents. However, as has been noted in the previous chapter, the respondents did not link the items together into the expected conceptual groups. That is, items which had been identified during the design 
of the questionnaire as representing a particular approach, such as questions 48 and 56 which represented the audio-lingual approach, were not linked together by the respondents but instead each question was responded to as an isolated concept. Thus, summarizing the data in terms of preference for a certain approach is not supported by the data.

This said, two tendencies can be noted within the student responses. Firstly, the ideals of the communicative approach were supported more than the ideals of the audio-lingual approach or the grammar translation approach. Secondly, the ideals of an approach were ranked higher than the implementation of that approach (procedures), except the grammar translation approach whose language ideals scored very low but whose language learning procedures gained medium scores. This can be seen in Figure 11 (chapter IV) where questions 47-57 (regarding the implementation of methodological ideals) tended to score lower than questions 41-46 (language ideals). It appears that students' opinions about language learning ideals were stronger than their beliefs about procedures. For example, students ranked ideals related to the communicative approach the highest of questions 41-62, but ranked several items which described procedures which implemented those ideals low. Question 55 "During class, I should practice using the English language with small groups of other students" was ranked 6th lowest of questions 41-62, and the 2nd lowest procedure. The procedure that was given the lowest score concerned the inductive learning of grammar (question 57). Teachers' rankings showed less distinction between ideal and practice. This disparity between ideals and procedures could have occurred because of a weakness in the questionnaire items, because students had not 
thought about language learning, or because the suggested procedures were unknown or not appealing.

Teachers were asked if they had been taught a methodology class by a native English speaker and if so, whether they had implemented any of the methods and whether students had responded well to these methods. Of the 34 teachers, 18 had been taught a methodology class by a native English speaker and 16 had implemented a Western method; however, 5 of the responses referred to classroom techniques rather than actual teaching methods (admittedly this distinction is easily blurred and in some cases may be artificial). The methods reported were Top-down (1), Communicative approach (7), the Functional approach (1), Cooperative learning (2). The remaining five responses were varied; one teacher wrote "techniques in teaching listening etc." and another wrote "to conduct my students to give their own answers". Three Chinese teachers reported that students reacted negatively to the identified approach. The three negative responses concerned the Top-down approach (1) and the Communicative approach (2).

While no single predominant method is suggested as desirable by the respondents, some beliefs and preferences can be observed regarding the language learning process. (a) Students prefer to have clear grammatical instruction (question 50) instead of inductively working out grammar points themselves (question 57); (b) Students agree that they are responsible for what they learn (question 51) 4 and that it is good to make mistakes (question 52); (c) Students wish to use language (question 46) but are not enthusiastic about practicing language through oral drills or small group work (question 55).

${ }^{4}$ This question ties in with the concept of respect towards teachers and so may not reflect a method. 
(b) It is difficult to make a conclusion about a specific preferred method from this second section. However, the results seem to suggest that a reason for the contradictory reports about methodology in China could simply be that there is no consensus about language learning methodologies or practices. The reason for such contrast between ideal and practice is unclear. It could indicate that the relationship between theory and practice has not been explored by many teachers and students or that process is less important than product. On the other hand, this contrast may indicate the respondents' ability to adapt their beliefs about language learning and their teaching or learning styles to the immediate situation.

Research Question 3 (a) What are the views about education prevalent in China among English language learners and teachers in Chinese universities? (b) Do the prevalent views about education lend themselves to the use of a particular methodology? If so, what methodology?

(a) The questionnaire was weak in the area of educational views. The educational views stated were biased in number towards Western views. However, in terms of questions 58-62, it can be concluded that Chinese students most believe that they should be able to interrupt the teacher with questions and comments (question 59), and be able to choose what they learn in school (question 61). Questions 58 "Education is learning how to learn" and 60 "Education occurs primarily through extensive reading" had the same mean of 2.43 which indicated a marginal agreement. The greatest disagreement (3.33) to any question in this section was attributed to question 62 "The aim of education is to get a good job". Students marginally disagreed with this question giving it the second lowest overall score. This response contrasts sharply with Western trends. Western education in the U.S. and 
O.E.C.D. (Organization for Economic Cooperation and Development) countries is increasingly focusing on vocational training. In fact, a survey of full-time freshmen entering American colleges and universities indicates that "of the freshmen entering college in the fall of 1991... 79\% (compared to $71 \%$ in 1976) say that getting a better job is a 'very important' reason for their decision to go to college" (Astin, 1992, p. 245). With jobs no longer guaranteed or found by the Chinese government, the increase of competition, and as privatization gains momentum, Chinese students' motivation to study may change to become more vocation oriented.

(b) Because these questions were biased towards Western educational views, its is difficult to draw methodological implications from this section. Research Question 4 (a) What is English needed for in China? (b) How does this affect the way English is taught, the methodology and curricula?

(a) Questions 12 and 25-40 of the questionnaire were based around this research question. Question 12 dealt with which subjects students needed English for, but was not answered as expected (see chapter IV). The answers to question 12 perhaps indicate the areas in which China is less strong, and in which information in English is useful.

Four factors were generated from questions 25-40 about what the English language was used for and how important it was to use English. Students gave similar scores for importance and frequency of use for all items and so these will be discussed without distinction. The four factors were tasks, language skills, exchange of information and audience. From the responses of students to questions 25-40, students' main concern was the use of English for work and study. Students identified the language skills as their second priority, followed by using English to exchange information. The audience or 
participants of communication were considered the least important of the four factors related to English usage. That is, students' considered the ability to use the language skills while working or studying more important than giving or receiving information and the people being communicated with. This response may reflect that the respondents are still students or that they anticipate using English mostly for listening and reading.

Teachers' opinions about what their students needed English for differed from the students'. The ranks that teachers gave regarding the importance and frequency of items were strongly correlated. Teachers identified the four language skills as what were most important and most used for students. They ranked the exchange of information second, followed by tasks, and the audience last.

(b) The common theme of students' and teachers' responses was the stress on receptive skills and receiving information. This would suggest that the respondents are applying the government's suggestion by using English to receive information with the goal of modernization. It is noteworthy that all of the items that implied direct oral communication (audience) were ranked low by teachers and students. Most methodological development related to language teaching in Western countries has emphasized the ability to speak the target language. The tendency of Chinese teachers and students to consider speaking less important or perhaps to avoid speaking, was bound to be noticed by Western teachers, as did Ye and Li (1988) and Mauger, Mauger and Kay (no date).

Research Question 5. Is the communicative approach appropriate to the curriculum and use of English in China? If not, could it be adapted? 
(a) Before answering this question it is useful to clarify two terms: communication and communicative. Communication is defined as "something that communicates [makes known] information from one person to another, a letter or message" (Oxford Paperback Dictionary, 1983, p. 125). The communicative approach stresses that languages are important vehicles of communication and prescribes a language learning process that emphasizes the use of language to convey meaning. While it is possible that language learning methodologies other than the Communicative approach will stress communication, the Communicative approach almost always will.

From the above section, it can be seen that the ideals of the communicative approach were met with ready agreement from students and teachers but that implementations of procedures based on these ideals met with less enthusiasm. However teachers' responses to question 12 showed that some teachers in China have implemented the Communicative approach with varied success. Of the 7 teachers who reported that they had implemented the Communicative approach, 2 were Americans and 5 were Chinese. Two of the 5 Chinese teachers found that students responded negatively to the Communicative approach.

It would seem from the above discussion that the following areas of the Communicative approach would meet with most resistance from students: active participation by learners, speaking in class, risk-taking, emphasis on process vs. product, and small group work. Several of these areas have been identified by foreign teachers as points of frustration.

This does not mean that the Communicative approach is unable to be used in China. What it does indicate is that, consistent with the recommendations of Oxford (1990) cited earlier, the procedures used in 
Western countries may need to be adapted for use in China, and the English curriculum in China may need to be adapted for the Communicative approach to be of use. The areas which could be focused on for change will be discussed in the 'implications' section.

One factor which may be important for Western teachers to bear in mind when teaching in China is the use of group discussion. The Communicative approach utilizes discussion and debate. Over the last fifty years, discussion and debate have often been the precursors to punitive measures in China. For example, the year of one hundred flowers led to discussion of government practices which in turn led to retribution. Similarly the encouragement of humanities and greater freedom and discussions in the 1980s led to the Tian'anmen Square massacre of 1989. The Communicative approach thus, while having some good tenets, poses Chinese students today with a dilemma: will their speech be held against them in several years time during some kind of 'political reform'. Chinese students in the United States or other Western countries cannot be presumed a different case: one Chinese student recently told me that an acquaintance of hers from China had been employed by the government to report on fellow students abroad (she qualified this by saying that most attention was directed to obvious dissenters). It is the responsibility of English teachers in China, or of teachers of Chinese students abroad, to (i) understand students' silence on some topical issues and (ii) where group discussions are employed, to avoid topics that could cause students to be endangered or suspected of holding counterrevolutionary ideas. It would be wise to stick to subject matter devoid of political references or evaluation of governmental policies. 
The above is unlikely to be the sole reason for students' 'silence' in the classroom. In fact, learning styles, their traditional role as passive learners, desire to learn the receptive skills, and other such factors are more influential. Huang and Van Naerssen suggest that for Chinese students to talk more in the classroom the teacher would have to 'create culturally acceptable conditions that would support risk-taking' (1987, p. 294). These 'culturally acceptable conditions' may include the development of a classroom where face-saving is not the priority, suggesting active language learning strategies, removing peer reporting and greater freedom of speech. For example, planned spoken activities such as dramas or speeches may feel safer for students.

While the goals of a method can be clearly defined, it is difficult to assess the value or applicability of that method in a given context. It is even more difficult to decide whether an approach can be transplanted crossculturally. In the case of the communicative approach, difficulties come from the implementation of the ideals, not the ideals themselves. This suggests that adaptation of the communicative approach to learners in China may render it not just usable but beneficial to students and teachers in China. Research Question 6. How do the methodologies identified in $1 b, 2 b, 3 b$, and $4 b$ contrast with the methodologies prevalent in the United States of America?

The field of English teaching in the United States of America has not arrived at a unified consensus about what should be taught and how. Many teachers are eclectic. There is, however, widespread support for the Communicative approach. If this survey is representative, we can see a similar lack of consensus in China. From the teachers' responses, there was 
substantial support for Western methods as opposed to Chinese methods (questions 19 to 24), and in particular the ideals which undergird the Communicative approach received strong support. However actual teaching practices did not seem to match up with the ideals supported. We may be able to conclude that the practical implementation of the approaches was in general not linked to ideals but rather treated as separate entities. The responses to $12 \mathrm{~b}$ "which methods have you implemented" indicates possible confusion between methods and procedures (classroom implementations) by some English teachers in China. This questionnaire would have benefited from a supplementary description by teachers of a typical class period. These descriptions would have confirmed or elaborated teachers' reported beliefs.

It may be a good time to note the advice of Yorio, who, after examining a new method and reviewing several older ones commented that:

Proponents and supporters of specific methods have only convinced some people, some of the time. Could it be that despite the soundness, appropriateness, and validity claimed for these methods, they fail to account for the 'variability' factor in both learners and teachers? If this is true, the only method that will ever be acceptable and effective with everybody is one based on an eclectic approach, a method that is flexible enough to cope with both individual student differences, and with teacher strategies and preferences. Until we find the elusive final answer in second language learning, a sensible and sensitive eclecticism appears to be the only alternative. (Yorio, 1981, p. 50)

It would seem that for China at least, no method fits perfectly. This does not mean that all methods should be dismissed, as Yorio implies, but indicates that it will take time to adapt Western methods and procedures to China and to produce culturally and contextually appropriate curricula. 


\section{LIMITATIONS OF THIS STUDY}

1. This study covered only a small number of students from a few universities. Also a 'convenient' rather than a true random sample of students and teachers were surveyed. Therefore the survey results should not be seen as representative of all students and teachers in China.

2. Several sections of the questionnaire need major revisions. Four questionnaire items were translated in a way that was different from the English. Question 12 rendered largely unusable results. Question 60 (Education occurs primarily through extensive reading) was translated as "To receive an education it begins mainly with wide reading"--slightly different from the intended meaning. Question 42 (A language is made up of many rules) comes across in the Chinese translation as less dogmatic than it does in English. Question 50 (The teacher should explain grammar clearly) may have been better written as "The teacher should (take time to) explain grammar" so that the emphasis was on the act of teaching grammar rather than the clarity of the explanation.

The last section (views about language, language learning and education) was rather theoretical and would have been easier for the participants to respond to and interpret if it had focused on the implementations of ideals/methods. The educational views were heavily biased toward Western views. Appendix E suggests a possible replacement of the last page in less theoretical terms.

The third section of the original questionnaire should, in retrospect, have concentrated less on the audience and more on the form of communication (telephone, books, journals, and so on). This would have 
changed the focus of the questionnaire from general goals to specific details, but would have been a little more concrete.

3. The questionnaire did not include a survey of national policy makers. In addition the national curriculum was not read. These factors considerably weaken the statements about language teaching practice in China.

\section{DUBIN AND OLSHTAIN'S FRAMEWORK}

Returning to Dubin and Olshtain's (1986) framework for curriculum design (see Figure 1), it is now possible to use the information gained from the survey and literature review, to summarize the beliefs of the respondents, by filling in the details of the framework.

The first layer of the three-tiered framework stresses four facets of the language learning context.

(i) Language setting: English is the major language of wider communication between China and other countries, and as such is the foreign language that is most emphasized.

(ii) Patterns of language use in society: Learning English is compulsory from middle school to the second year of university. English is needed to undertake research, as few English journals are translated into Chinese. However, English is not the standard language of instruction at school and for the large majority of university classes. The professions which are stressed as needing English are those which are not strongly established in China. 
(iii) Group and individual attitudes about the process of language learning and the target language: From the questionnaire (13-24) it would appear that many respondents have positive attitudes towards native English speakers and things that are Western. Various attitudes exist about language learning, but the need for the receptive skills of reading and listening was consistently stressed by teachers and students alike.

(iv) Political and National context: Eight Chinese dialects are spoken in China. Putonghua (Mandarin) is the national language. The government has encouraged the learning of English to assist the process of modernization. A national curriculum is used and national university entrance exams include an English exam.

The second tier of Dubin and Olshtain's framework examines existing views about language, language-learning and education-culture. From the survey, views about language emphasized that language consisted of social and cultural elements and was the means to communication: a socio-cultural view. The respondents' views about language learning were mixed. Dubin and Olshtain discuss three major views about language learning: cognitive, holistic and stimulus-response (1986, pp. 69-75). The respondents of the questionnaire did not fall clearly into any of these language learning views as discussed above: a mixed response. The respondents' view of education appeared to fit into the humanistic view - students wanted to be able to choose what they learnt in school (question 61) (teachers agreed less), and both students and teachers agreed that students have more responsibility for their learning than the teacher does (question 51). However students were not enthusiastic about group work (question 55) or inductive learning (question 57). This affirms Young and Lee's finding that Chinese teachers and learners 
prefer methods favoring transmission (teacher centeredness) over methods favoring interpretation (student centeredness) (1983, pp. 193-4). In this sense, students were being passive and fitting closer to the behavioristic approach: again a mixed response.

Richards and Rodgers (1986) suggest that language methodologies can be classified as structuralist, functional or interactional (see literature review). From the questionnaire we can identify the position of Chinese language teaching. The interactional position (that languages exist for interpersonal relationships) as shown by the audience factor (from questions 25-40), received comparatively little support. The structural view, that mastery of language components leads to language proficiency, is seen by the teachers' emphasis on the separate language skills (the skill factor of questions 25-40). The functional view of language learning was supported by the students in their high ranking of the tasks factor of questions 25-40. Thus teachers may be seen to prefer the Grammar-Translation approach or the Audio-Lingual approach, whereas students may prefer the Communicative approach or English for Specific Purposes syllabi.

Dubin and Olshtain indicate that the combination of language, language learning and educational views will lead to a language learning methodology. In this case, there appears no clear conclusion.

The third layer of Dubin and Olshtain's framework examines the objectives of language learning. Language, language learning, and educational-cultural views provide the theoretical goals of a curriculum. These goals are implemented with regard to language content, process/means and product/outcomes (Dubin and Olshtain, 1987, p. 43). Which of these areas are stressed determines the focus of the curriculum or syllabus. That is, focus 
on language content stresses language/thematic items and order of presentation; a focus on process/means highlights how language is presented, the role of the participants, and the materials used; and a focus on the product or outcome emphasizes what the learner will know, be able to do, specific situations of use such as examinations, work-places, and assessment (p. 42). Of the three tiers, the conclusions are most clear at this tier concerning language learning objectives. Students focused on the product/outcomes of the language course: their implementation of what they had learnt. Teachers tended to focus on language content. Certainly the process was not the most important aspect of the language course. This explains to a certain degree why the respondents' views about language, language learning and educationculture were fairly non-committal: these simply were not the focus for the given respondents.

Figure 12 summarizes the information gained about language teaching in China. The participants emphasized the final section of Dubin and Olshtain's framework: the end product. Many Western teachers would have emphasized the second section: the process used to teach. 

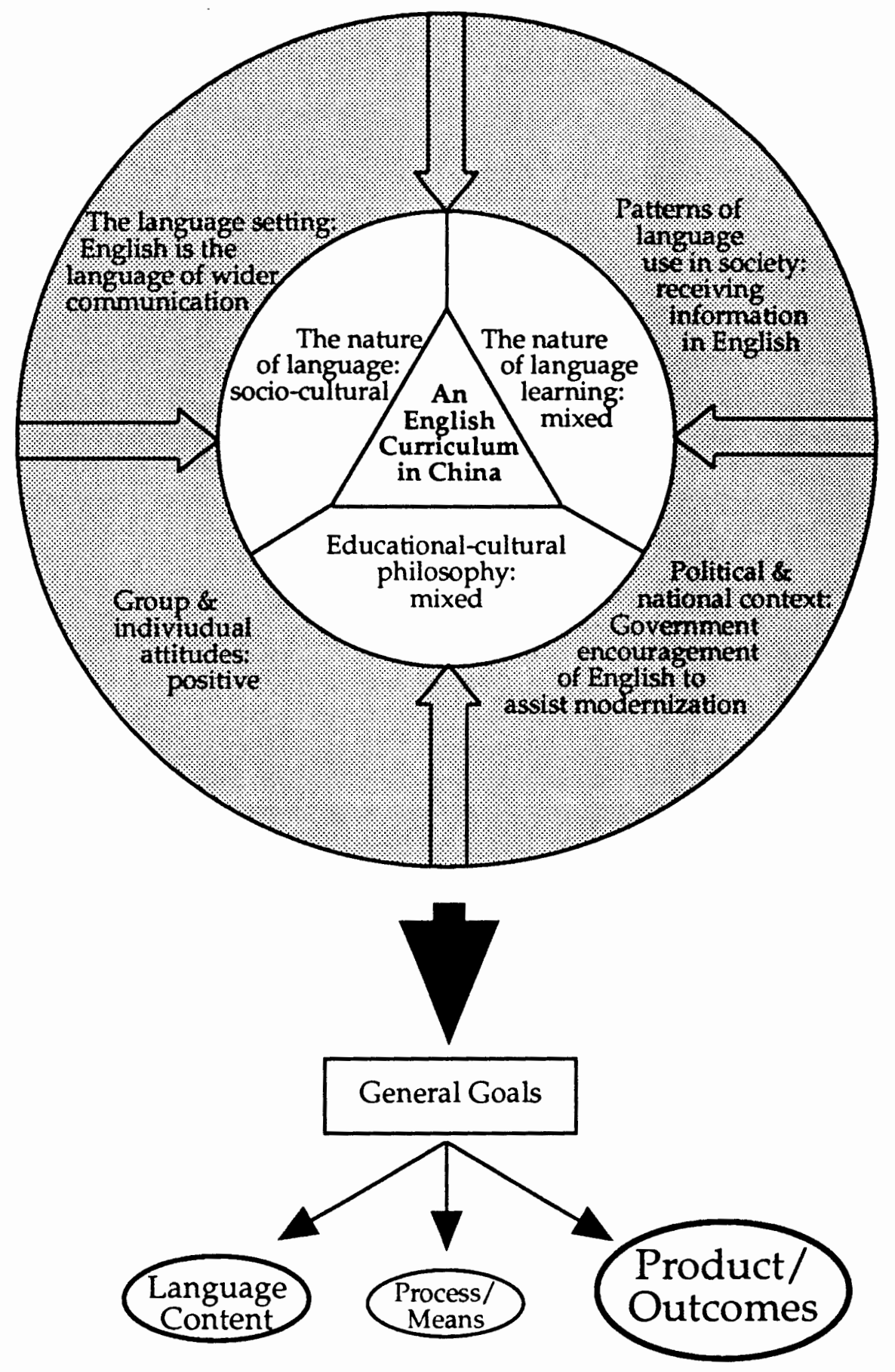

Figure 12. Summary of the questionnaire information using Dubin and Olshtain's (1986) framework for curriculum design, noting priority for product over other program goals. 


\section{IMPLICATIONS FOR TEACHING IN CHINA/ CURRICULUM}

\section{DEVELOPMENT}

1. Perhaps the most striking conclusion that can be drawn from this study is that it confirms existing research which identifies Chinese teachers and learners as product oriented rather than process oriented. This is indicated by the teachers' concentration on the acquisition and development of language skills and students' focus on the target implementation of their language learning in work and studies. The fact that there was virtually no correlation between many conceptually related questions about methodologies provides further evidence of the de-emphasis on process. As China continues to open to the West and adopt aspects of Western culture it is likely that methodologies could become sought after and have greater desirability. However at the present time, Western teachers in China and any externally written curricula should be sensitive to the focus of the Chinese learners. That English is a Western language does not imply that it should be taught using Western methods. New ideas introduced by Westerners in English language programs in China should be implemented gradually and adapted to the ideas of the Chinese culture, local students, and Chinese language learning processes. Consideration for the Asian tendency to prefer the known route over the experimental route would slow the process of implementation but ensure that the new methods or procedures were perceived to have greater relevance for the students.

2. The focus of language learning and teaching in China appears to be language skills and the intended implementation of those skills. Thus, where students do not perceive that they will use English, they have less motivation 
to learn (as indicated by the coordinator from Anhui Medical University). On the other hand, when students have identified a situation for which they need English, learning English becomes much more important (such as the post-graduate students, English teachers and students intending to travel overseas). ESP curricula could work well in China by enabling the focus of language learning to be the product. It would be unwise to provide an unbalanced curriculum in terms of language skills because this would limit the students. Competent future Chinese researchers may be rendered unable to share their findings with their peers in English-speaking countries if only receptive skills are prioritized.

3. In situations where the language curriculum can be adapted, (i.e. isn't governed completely by national exams and national curricula), a detailed needs analysis which focuses on the target language situations, specific subject areas, and types of information students need to receive, could provide information that is sufficiently specific to guide which subject matter is studied: thematic, linguistic, and language form (text type).

4. Two areas which, if changed, would act towards closing the gap between Western and Chinese classroom practice are (a) a greater emphasis on speaking in the classroom, and (b) reduced class sizes.

(a) Speaking: As has been mentioned, students and teachers both indicated that speaking was less important than listening and reading. Communication with other people in English gained low scores (see the audience factors of questions 25-40). An avoidance of speaking in English could be the result of several things: (i) speaking exposes the learner to embarrassment and loss of face in front of peers, (ii) students may lack self confidence, (iii) the speaker stands out from the collective group, (iv) national 
exams do not include an oral section, thus speaking ability does not affect students final grades, (v) discussion of social issues could be met with repression. A move towards greater emphasis on speaking would have many implications for educational curricula. Encouraging verbal participation in class has taken time, seminars, teacher training, and student cooperation in order to be achieved in Western countries and would need equal amount of effort to succeed in China. The greatest motivation to teach and practice speaking in English would probably come from inclusion of speaking in examinations: this would be time consuming but would ensure that spoken language practice occurred.

\section{SUGGESTIONS FOR FURTHER RESEARCH}

The following suggestions for future research are not sufficient in themselves to provide the wealth of information still needed if Chinese learners are to be sensitively provided for in the language classroom, but may provide some ideas which could, in turn, be elaborated upon.

Chinese language learners could be surveyed over the next few years to see whether, as China develops its presence in the international marketplace, they become increasingly vocation oriented in their studies. If so, this would provide an even stronger case for the use of English for Specific purposes syllabi.

A survey of Chinese teachers of English asking them for an outline of their daily routine in the language class, or a classroom observation study conducted by a Westerner with a thorough knowledge of methodology, could be used to analyze classroom procedures in China. 
The above survey of teachers' procedures in the classroom could be contrasted with several Western procedures, and used to develop a questionnaire about classroom practices and procedures. This in turn could be used to survey students. The data gained would be likely to provide more concrete guidelines about Chinese students' learning preferences.

It would also be beneficial to examine where the impetus for change in Chinese language learning settings is coming from. If Westerners had not criticized Chinese methods of teaching, would there have been a move for change and if so, what areas would have been targeted for change? How do Chinese teachers feel about accommodating Westerners and using Western methods?

A possible extension of this study would be to give the questionnaire to American students to see whether they respond in a way that is similar to or different from the participants of this study. This would provide a basis for a comparison of student preferences and beliefs.

An analysis of the national English curriculum and national English exams used in China is an obvious and necessary step to understanding English language teaching in China. Dubin and Olshtain's framework could be used to identify and clarify national goals and priorities.

This survey has not provided answers to all of the questions posed, but could perhaps be seen as a small start towards greater understanding of English language teaching and curricula in the People's Republic of China. 


\section{REFERENCES}

Aronowitz, S. (1981). Preface. In H. A. Giroux (Ed.), Ideology, culture and the process of schooling. Philadelphia: Temple University Press.

Astin, A. W. (1993). What matters in College?: Four critical years revisited. San Francisco: Jossey-Bass Publishers.

Barkley, M. (1994). Private education in public China. China Council Quarterly 53 , pp. 13-14.

Benson, N. (1988). The people's soul engineers: A study of secondary school teachers in the People's Republic of China. Unpublished doctoral dissertation, Portland State University, Oregon.

Berwick, R. (1989). Needs assessment in language programming: From theory to practice. In R. K. Johnson (Ed.), The Second Language Curriculum (pp. 48-62). Cambridge: Cambridge University Press.

Bowen, J. D., Madsen, H., \& Hilferty, A. (1985). TESOL techniques and procedures. Rowley, Massachusetts: Newbury House.

Brindley, G. (1989). The role of needs analysis in adult ESL programme design. In R. K. Johnson (Ed.), The Second Language Curriculum. (pp. 63-78). Cambridge: Cambridge University Press.

Brislin, R. (1986). The wording and translation of research instruments. In W. J. Conner \& J. W. Berry (Eds.), Field methods in cross-cultural research (pp. 137-164). Beverly Hills: Sage Publications.

Burchett, W., \& Alley, R. (1976). China: The quality of life. England: Penguin Books.

Burnaby, B., \& Sun, Y. (1989). Chinese teachers views of Western language teaching: Context informs paradigms. TESOL Quarterly 23 (2), 219-238.

Cao, X. (1991). Policy-making on the improvement of university personnel in China under the national reform environment. Studies in Higher Education, 16 (2), 103-115. 
Celce-Murcia, M. (1991). Language teaching approaches: an overview. In M. Celce-Murcia (Ed.), Teaching English as a second or foreign language (2nd Ed.) (pp. 3-11). Boston: Heinle and Heinle.

Cogan, J. J. (1986). Chinese perspectives on China. Social Education, 50 (2), $112-$ 117.

Cohen, L., \& Manion, L. (1980). Research methods in education. London: Croom Helm.

Converse, J. M., \& Presser, S. (1986). Survey questions: Handcrafting the standardized questionnaire. Beverly Hills: Sage Publications.

Dubin, F., \& Olshtain, E. (1986). Course design: Developing programs and materials for language learning. Cambridge: Cambridge University Press.

Editorial department of the PRC yearbook. (1988). The People's Republic of China yearbook 1988/1989. Beijing: Xinhua Publishing House.

Englesberg, P. (1994). China moves to curb brain drain. China Information Bulletin 4 (3), 4. Portland, OR: North West Regional China Council.

The Europa World Year Book, (1993), (34th ed.), (pp. 744-763). London: Europa Publications.

Field, M. L. (1984). A psycholinguistic model of the Chinese ESL reader. On TESOL ' $84,171-182$.

Fitzgerald, C. P. (1992). The People's Republic of China: History up to 1966. In The Far East and Australasia 1992, (23rd ed.), (pp. 185-189). London: Europa Publications.

Fox, D. N. (1989). Chinese voices: Toward an ethnography of English as a second language. Unpublished master's thesis. Portland State University, Portland, OR.

Freeberne, M. (1992). The People's Republic of China: Physical and social geography. In The Far East and Australasia 1992. (23rd ed.). London: Europa Publications.

Frey, L. R., Botan, C. H., Friedman, P. G., \& Kreps, G. L. (1991). Investigating communication: An introduction to research methods. Englewood Cliffs, NJ: Prentice Hall.

Gaines, J. A. (1994) Private Correspondence. 
Glass, G. V. \& Hopkins, K. D. (1984). Statistical methods in education and psychology. (2nd ed.). Englewood Cliffs, NJ: Prentice-Hall Inc.

Grabe, W., \& Mahon, D. (1982). Teacher training in China: problems and perspectives. On TESOL ' $82,47-60$.

Griffith, S. (1991). Teaching English abroad: Talk your way around the world. Oxford: Vacation Work.

Gutek, G. L. (1986). Education in the United States: An historical perspective. Englewood Cliffs, NJ: Prentice Hall.

Hayhoe, R. (1993). China's universities since Tiananmen: A critical assessment. The China Quarterly: An international journal for the study of China, 134, 291-309.

Henderson, G. (1993). Survival guide to survey research in China. China Exchange News: A review of the education, science and academic relations with the P. R. C., 21 (1), 23-25, 33.

Hsu, I. C. (1990). The rise of modern China. Oxford: Oxford University Press.

Hu, W. Z. \& Grove, C. (1991). Encountering the Chinese: a guide for Americans. Maine: Intercultural Press.

Huang, X., \& Van-Naerssen, M. (1987). Learning strategies for oral communication. Applied Linguistics, 18 (3), 287-307.

Hutchinson, T., \& Waters, A. (1987). English for Specific Purposes: A learningcentred approach. Cambridge: Cambridge University Press.

Johnson, R. (1989). A decision-making framework for the coherent language curriculum. In R. K. Johnson (Ed.), The Second Language Curriculum, (pp. 1-23). Cambridge: Cambridge University Press.

Klein, M. H., Alexander, A. A., Tseng, K., Miller, M. H., Yeh, E., Chu, H., \& Workneh, F. (1971). The foreign student adaptation program: Social experiences of Asian students in the U. S. International Educational and Cultural Exchange 6 (3), 77-90.

Lado, R. (1986). How to compare two cultures. In Joyce M. Valdes (Ed.), Culture bound: Bridging the cultural gap in language teaching. (pp. 5263). Cambridge: Cambridge University Press. (Original work published 1957) 
Lamoureux, A. (n. d. - c. 1986). Some personal observations and comments. In Papers by Chinese and foreign teachers to the second provincial symposium on teaching foreign languages (pp. 57-59). Hubei, China: Foreign affairs section Hubei provincial education commission.

Li, D. J. (1978). The ageless Chinese: A history. (3rd ed.). New York: Charles Scribner's Sons.

Li, H. L. (1982). Language and culture. TESL Talk, 13 (3), 92-95.

Lieberman, J. (1984) The Chinese Association for English Language Education: It's origin, work and projected goals. TESOL Newsletter, 18 (4), 18-19.

Maley, A. (1986). XANADU - "A miracle of rare device": The teaching of English in China. In J. M. Valdes (Ed.), Culture bound: Bridging the cultural gap in language teaching (pp. 102-111). Cambridge: Cambridge University Press.

Mao, T. T. (1966). Report on an investigation of the peasant movement in Hunan. In Quotations from Chairman Mao Tse-tung (pp. 11-12).

Beijing: Foreign Language Press. (Original work published 1927)

Mauger, A., Mauger, S., \& Kay, S. (n. d.). Teaching conversational English at the Wuhan Technical University of surveying and mapping. In Papers by Chinese and foreign teachers to the second provincial symposium on teaching foreign languages (pp. 72-79). Hubei, China: Foreign affairs section Hubei provincial education commission.

Messerschmitt, D. S. (1986). Language and people of China's cultural revolution. TESOL Teacher Education Newsletter TE-IS, $\underline{3}$ (1), 1-4.

Moffett, O. E. (1983). State of the art of foreign language education in the People's Republic of China. Foreign Language Annals, 16 (1), 13-17.

Nunan, D. (1989). Understanding language classrooms: A guide for teacherinitiated action. Hertfordshire UK: Prentice Hall.

Nunan, D. (1992). Research Methods in Language Learning. Cambridge: Cambridge University Press.

The Oxford Paperback Dictionary. (1983). (2nd ed.). Oxford: Oxford University Press.

Oxford, R. (1990). Language learning strategies: What every teacher should know. New York: Newbury House Publishers. 
Oxford, R., Hollaway, M., \& Horton-Murillo, D. (1992). Language learning styles: Research and practical considerations for teaching in the multicultural tertiary ESL/EFL classroom. System, 20 (4), 439-456.

Paine, L. (1986a). In search of a metaphor to understand China's changes. Social Education 50 (2), 106-109.

Paine, L. (1986b). Timeline of Chinese policy changes: 1949-85. Social Education, 50/2, 110-111.

Pia, A. A. (1989). Preferred perceptual learning styles of Chinese students. Unpublished master's thesis. Portland State University, Portland OR.

Richards, J. C. (1990). The language teaching matrix. Cambridge, Cambridge University Press.

Richards, J. \& Rodgers, T. (1986). Approaches and methods in language teaching. Cambridge: Cambridge University Press.

Robinson, J. C. (1986). Decentralization, money, and power: the case of peoplerun schools in China. Comparative Education Review, 30 (1), 73-88.

Rosen, S. (1993). The effect of post-4 June re-education campaigns on Chinese students. The China Quarterly, 134, 310-334.

Sato, C. (1981). Ethnic styles in classroom discourse. On TESOL '81, 11-24.

Savada, A. M., \& Dolan, R. E. (1988). Education and culture. In R. L. Worden, A. M. Savada, \& R. E. Dolan, (Eds.), China, a country study (4th ed.) (pp. 151-204). U.S.A.: Library of Congress, Federal research division.

Saville-Troike, M. (1978). A guide to culture in the classroom. Rosslyn, VA.: National Clearinghouse for Bilingual Education.

Sowell, T. (1993). Inside American education: The decline, the deception, the dogmas. New York: The Free Press.

Spence, J. D. (1986). China, 1830-1949. Social Education, 50 (2), 102-105.

Stevenson, H. W. \& Stigler, J. W. (1992). The learning gap: Why our schools are failing and what we can learn from Japanese and Chinese education. New York: Summit Books.

Tabachnick, B. G. \& Fidell, L. S. (1983) Using multivariate statistics. Cambridge: Harper and Row. 
Tang, L. X. (1983). TEFL in China: Methods and techniques. Shanghai:

Shanghai Foreign Language Education Press.

The report of the Presidents commission on higher education for democracy. (1989). In L. F. Goodchild \& H. S. Wechsler (Eds.), ASHE Reader on the history of higher education. Needham Heights, MA: Ginn Press. (Original work published 1949)

Wang, C. (1988). A comparative study of Chinese EFL reading instruction and American ESL reading instruction. Unpublished master's thesis. Portland State University, Portland, OR.

Wang, C. (1993). Friendship patterns of Chinese students. Unpublished doctoral dissertation. Portland State University, Portland, OR.

Wardaugh, R. (1992). An introduction to Sociolinguistics. (2nd ed.). Oxford: Blackwell Publishers.

Watson, W. (1966). Early civilization in China. London: Thames and Hudson.

Webb, R. B. (1981). Schooling and society. New York: Macmillan.

Ye, X., \& Li, Y. (1988). From what we know to what we do. The Ortesol Iournal, 9 , 59-81.

Yorio, C. A. (1981). Teaching methods, the brain, and other simple matters, or are we ready for applied neurolinguistics. TESL Talk, 12 (1 \& 2), 50-59.

Young, R. (1987).The cultural context of TESOL - A review of research into Chinese classrooms. RELC Journal, 18 (2), 15-30.

Young, R., \& Lee, S. (1984). EFL curriculum innovation and teachers attitudes. On TESOL ' $84,183-194$. 
APPENDIX A

GUIDELINES FOR THE DEVELOPMENT OF THE QUESTIONNAIRE 


\section{GUIDELINES FOR THE DEVELOPMENT OF THE QUESTIONNAIRE}

The research questions largely parallel an implementation of Dubin and Olshtain's (1986) model of curriculum analysis. One practical difficulty with Dubin and Olshtain's model, is that their model relies heavily on participants' attitudes by focusing on views about language, views about language learning, and views about education. Attitudes are difficult to define and measure, due to their subjectivity. Agheyisi and Fishman (1970) demonstrate that one's definition of the word 'attitude' determines what one looks for and the method used to find it. For example, a mentalist approach defines attitudes as "a mental and neural state of readiness" (Allport cited in Agheyisi and Fishman, p. 138), that is, an internal element that cannot be observed but instead can be discovered by introspection alone. At the other extreme, a behaviorist believes that a person "locates attitude[s] in actual overt behavior or responses" (Bain cited in Agheyisi and Fishman, p. 138). Therefore, the behavioral approach concentrates on the study of behavior in specific social situations. Debate also exists over whether attitudes are single components or contain multiple variables such as knowledge, evaluation and action. Consensus does exist that attitudes are learnt from experience, affect behavior, and are somewhat enduring.

This study used a needs analysis as the instrument by which participants' attitudes were uncovered. The needs analysis included a portion from both the mentalist and behaviorist approach. That is, viewpoints held by participants were gauged using the mentalist technique of self-reporting. The reason the mentalist approach was favored here was purely practical: the participants' behavior could not be observed from a vantage point in the 
U.S.A.. However, a large section of the instrument discussed participants' actual use of language, thus incorporating aspects of the behaviorist approach.

A needs analysis is an instrument designed to find factors that influence a given learning situation. Needs analyses have been used in the field of TESOL as the basis for curriculum design.

Specific instruments for needs analysis are varied in what they identify as a need and what they measure. The term 'needs' is in itself ambiguous as definition of needs is subjective. Berwick (1989) comments that "our perception of need develops from what we believe is educationally worthwhile" (p. 56). Who is identifying a need thus influences what and how a need is defined. Berwick identifies four approaches to analyzing needs: discrepancy analysis, a democratic approach, an analytic approach and a diagnostic approach. Discrepancy analysis contrasts what a learner knows now with what he or she needs to know. A democratic or learner-centered approach consults the learners about what they see as their needs, then follows the majority opinion. In contrast, linguistic authorities in the analytic approach prescribe the goals, methods and views about language that will form the basis of the curriculum. The fourth or diagnostic approach, defines needs in terms of "the harmful consequences of a deficiency", usually concentrating on survival needs (Berwick, 1989, pp. 52-54). Hutchinson and Waters (1987) counsel that needs analyses negotiate a course of action from many sources. This would help to ensure the approval of all involved: learners, teachers, administrators, funders and so on. Frey, Botan, Friedman and Kreps (1991) also advise that participants be chosen carefully and caution that "the appropriateness of the sample of people asked to respond influences the kinds of responses elicited plus generalizability" (p. 185). 
Ideally, this study would have included a survey of national policy makers, language program administrators, English teachers and students in China to discover their views on language and education. While this was not possible, this study followed Hutchinson and Waters' suggestion to include several sources of data, by surveying teachers and students. The study adhered to what Berwick called the 'democratic approach', that is, groupings of attitudes and patterns of language use were tested for consensus. The reason the democratic approach was chosen over the diagnostic, analytic or discrepancy approaches, was to ensure that the focus of this study was the first two layers of Dubin and Olshtain's model, that is, on the context and underlying views that affect the learning of English in China.

The form that the needs analysis took was a questionnaire. The questionnaire format was chosen over other forms such as interviews because of constraints of space, and the greater effectiveness of questionnaires in gathering information from large and distant samples. Frey et al. (1991) point out that "the fact that many respondents can be given identical questionnaires make them a reliable measurement technique for survey research" (p. 193). Brislin (1986) suggests that pre-existing questionnaires should be avoided in research across cultures, as the original questionnaire was written in and tested with a different group of people. Hence, an original questionnaire was constructed for use in this study with reference to needs analyses written by Munby (1978), Nunan (1989), and Brindley (cited in Richards, 1990, p. 27) and also to Celce-Murcia's overview of TESOL methodologies (1991, pp. 5-8). Many factors determine whether the data gained by questionnaires is valid and reliable. Several of these are discussed below. 
Surveys can either be cross-sectional or longitudinal. A cross-sectional survey is a snap shot at one point in time, whereas a longitudinal study collects data over a period of time. Where a survey, such as this one, is crosssectional, the time that the data were collected must be taken into account: "results of cross-sectional surveys can be very misleading if the data are gathered at an unrepresentative point in time... [unrepresentative due to] personal as well as environmental circumstances" (Frey et al., 1991, p. 187). If data are assumed to have any stability, the immediate situation of participants in a cross-sectional study must be taken into consideration.

The way that questions are asked can also affect the results:

To gather valid data, researchers must create questions that are appropriate for the specific respondents they intend to survey...[that is] take into account respondents' educational levels and cultural backgrounds by posing questions that use language and ideas with which they are familiar, thus maximizing the chances that the survey questions will be understood and answered. (Frey et al., p. 190)

To this end, several rules of thumb have been formed for question writing. These tend to be a list of what to avoid: questions using negatives, vague terms, passive voice, use of pronouns (Brislin, 1986), lengthy questions (over 16 words), double barreled questions, implicit negatives, jargon, (Converse and Presser, 1986), questions that lead respondents to respond a certain way, emotionally charged terminology (Frey et al.), and so on.

The way that the questionnaire is formatted also has some effect on responses. Included in this is the order in which the questions are asked. Frey et al. recommend that, in general, demographic questions should come first, questions about the same topic should be together, and the format of the scales used should be varied in order to prevent respondents from answering each question in the same way. The task for the respondent should be 
manageable and clearly defined by a set of lucid instructions. In essence, the questionnaire should be clear, quick and easy (1991, p. 194).

How the questionnaire is presented can also influence the questionnaire, by giving the respondent a positive or negative feeling about participation. Many researchers note that it is important for respondents to have an idea of why their participation is useful. They suggest that a cover letter explaining the research be enclosed, in which anonymity is assured. Cohen (1980) summarizes the goals of questionnaire writing well: "An ideal questionnaire possesses the same properties as a good law: It is clear, unambiguous and uniformly workable... and elicits answers as close as possible to the truth" (p. 103).

The final version of the questionnaire used in this study endeavored to follow the above advice. This said, in some cases the advice given was contradictory. For example, Frey et al. suggest that the format used should vary so that respondents do not lock into a response set; however this made the questionnaire visually cluttered. Similarly, many authors note that questions should be stated in the positive, especially when an agree-disagree scale is being used. However, the use of the positive at times made the item in consideration appear leading. Thus the final questionnaire while attempting to follow the above guidelines, at times had to choose between two suggestions. The questionnaire is discussed in Chapter Three. 
References for Appendix A

Agheyisi, R., \& Fishman, J. (1970). Language attitude studies: a brief survey of methodological approaches. Anthropological Linguistics, 12 (5), 137157.

Berwick, R. (1989). Needs assessment in language programming: From theory to practice. In R. K. Johnson (Ed.), The Second Language Curriculum (pp. 48-62). Cambridge: Cambridge University Press.

Brindley, G. (1989). The role of needs analysis in adult ESL programme design. In R. K. Johnson (Ed.), The Second Language Curriculum. (pp. 63-78). Cambridge: Cambridge University Press.

Brislin, R. (1986). The wording and translation of research instruments. In W. J. Conner \& J. W. Berry (Eds.), Field methods in cross-cultural research (pp. 137-164). Beverly Hills: Sage Publications.

Cohen, L., \& Manion, L. (1980). Research methods in education. London: Croom Helm.

Converse, J. M., \& Presser, S. (1986). Survey questions: Handcrafting the standardized questionnaire. Beverly Hills: Sage Publications.

Hutchinson, T., \& Waters, A. (1987). English for Specific Purposes: A learningcentred approach. Cambridge: Cambridge University Press.

Munby, J. (1978). Communicative syllabus design. Cambridge: Cambridge University Press.

Nunan, D. (1989). Understanding language classrooms: A guide for teacherinitiated action. Hertfordshire UK: Prentice Hall. 


\section{APPENDIX B}

\section{CONSENT FORM AND QUESTIONNAIRES}

APPENDIX B includes all three versions of the questionnaire and the consent forms. They appear in the following order:

(i) Student questionnaire in English,

(ii) Student questionnaire in Chinese,

(iii) Teacher questionnaire in English. 


\section{Student Questionnaire}

Thank you for participating in this English language learning questionnaire. This research is being performed by a graduate student at Portland State University. The study is investigating the ways that Chinese students prefer to learn English and to find out what English is needed for.

Your answers to these questions will be very helpful. Please do not write your name on the questionnaire so that you will remain anonymous. There are no right or wrong answers. This questionnaire will not affect your grades at all, and participation is voluntary.

The questionnaire will take approximately 15-20 minutes to complete.

Thank you again.

Dr. M. Terdal (teacher)

Kirsten Ngan (student)

Consent: $\quad$ 1. I have read and understood the above information and agree to take part in this study (circle one) Yes No Date:

2. Would you like to receive a summary of the results of this study? Yes No

If you have concerns or questions about this study, please contact: Human Subjects Reseach Review Committee Chair Office of Research and Sponsored Projects 105 Neuberger Hall, Portland State University Portland, OR 97207-0751 United States of America phone: (503) 725-3417 
Please circle the appropriate answer(s) or write an answer in the space provided:

1. Age in years

2. Sex

3. What is your native dialect?

\begin{tabular}{lll} 
Male & \multicolumn{2}{c}{ Female } \\
Mandarin & $\begin{array}{l}\text { A Chinese } \\
\text { dialect other } \\
\text { than Mandarin }\end{array}$ & $\begin{array}{l}\text { A language } \\
\text { other than }\end{array}$ \\
& Chinese.
\end{tabular}

4. What other languages do you know?

5. How many years have you studied at a university?

6. What university are you attending?

7. How many years have you studied English?

8. How would you rate your proficiency in English?

poor fair average good very good

9. Are you studying for the TOEFL, GRE, or GMAT? Yes No

10a. Have you had a native English speaker teach you Yes No English?

10b. If yes, did that teacher teach in a way similar or Similar Different different to Chinese teachers?

11. Are you an English major at university?

Yes

No

12. Which of the following subjects or professions do you need English for? (circle all that apply to you)
(a) Administration
(b) Armed forces
(c) Commerce
(d) Computer Science
(e) Education
(f) Engineering
(h) Humanities
(i) Mathematics
(j) Medicine
(k) Science
(l) Service
(m) Social Science
(n) Other:

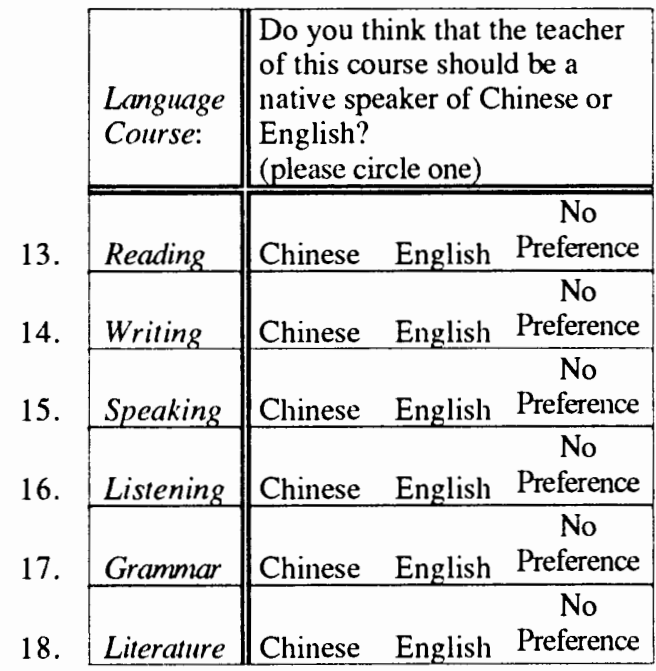

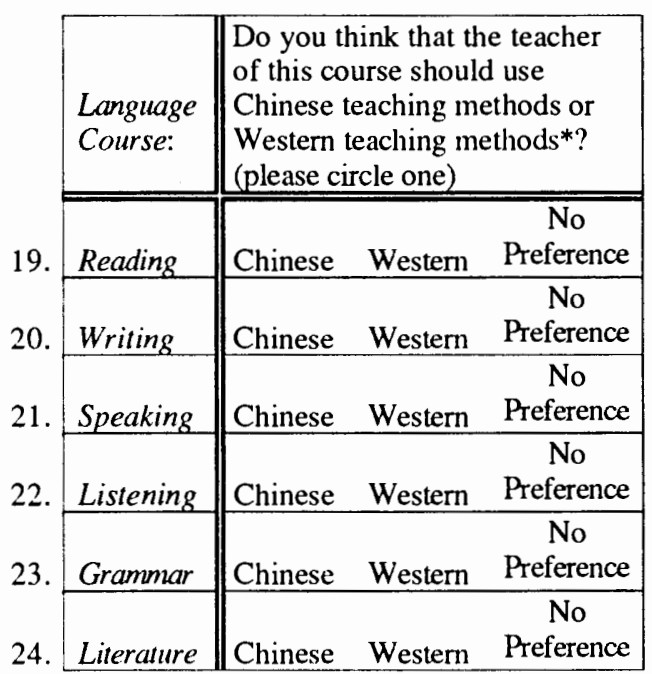

* nb: Chinese teaching methods may include traditional style lectures and memorisation. Western methods may include interaction between students in class. 
Please answer the following questions by circling how importcint the action is to you and how frequently you perform or will need to perform that action.

\begin{tabular}{|lllllll|}
\hline Importance & $1=\begin{array}{l}\text { Not } \\
\text { important }\end{array}$ & $2=\begin{array}{l}\text { Not very } \\
\text { important }\end{array}$ & $3=\begin{array}{l}\text { Fairly } \\
\text { important }\end{array}$ & $4=\begin{array}{l}\text { Very } \\
\text { important }\end{array}$ & $5=\begin{array}{l}\text { Extremely } \\
\text { important }\end{array}$ \\
\hline Frequency & $1=$ Never & $2=$ Rarely & $3=$ Occasionally & $4=$ Often & $5=$ Always \\
\hline
\end{tabular}

For example: Ineed to read English texts.

If it is very important for you to read English texts, circle 4 (very important) on the Importance scale.

If you read English texts occasionally, circle 3 (occasionally) on the Frequency scale.

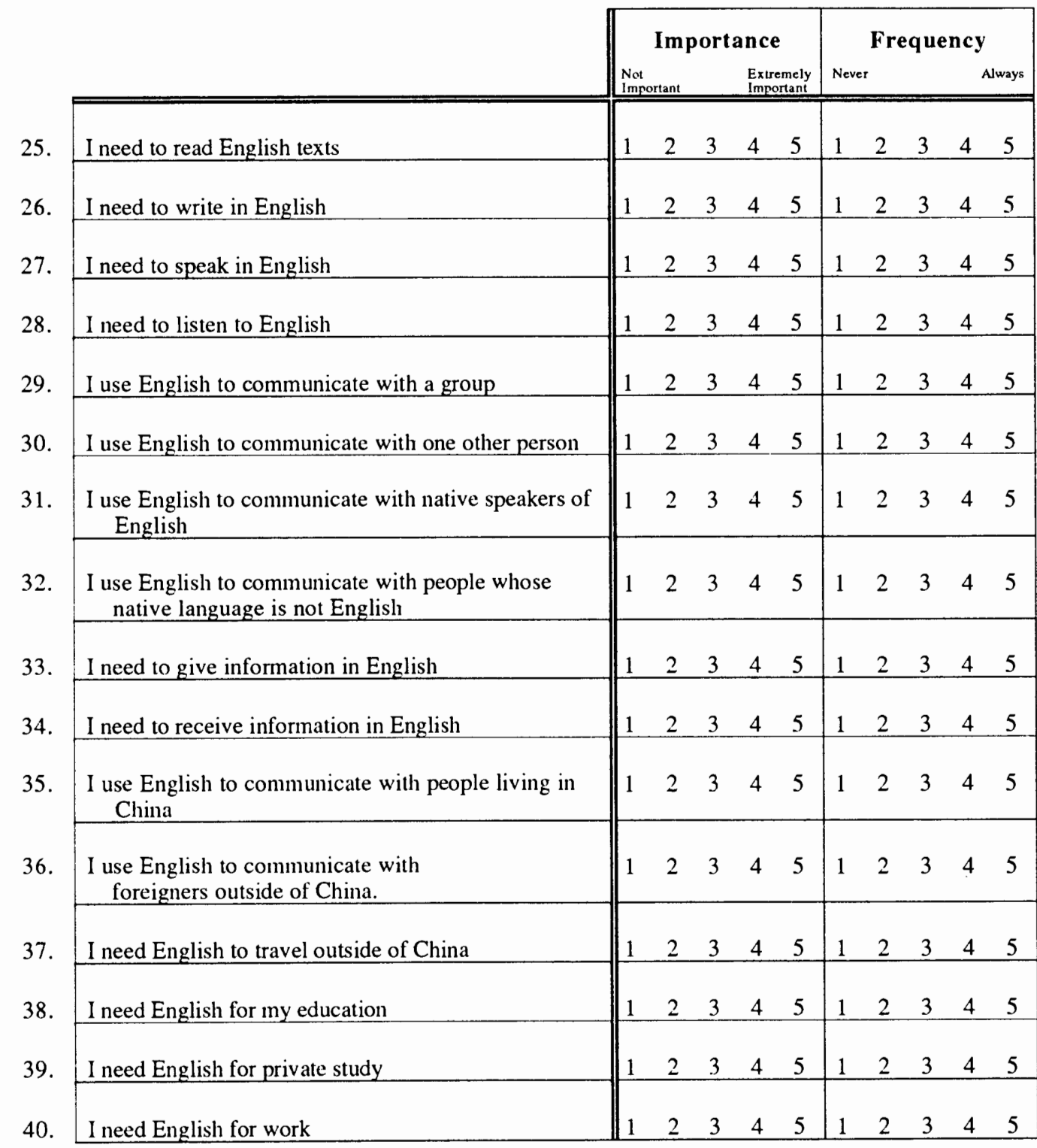


Please answer the following questions by indicating how much you agree or disagree with the statement.

\begin{tabular}{|c|c|c|c|c|c|c|}
\hline & & $\begin{array}{l}\text { Strongly } \\
\text { Agree }\end{array}$ & Agree & Neutral & isagree & $\begin{array}{l}\text { Strongly } \\
\text { Disagree } \\
\end{array}$ \\
\hline 41. & The purpose of language is communication & SA & A & $\mathrm{N}$ & $\mathrm{D}$ & SD \\
\hline 42. & A language is made up of many rules & SA & A & $\mathbf{N}$ & $\mathrm{D}$ & SD \\
\hline 43. & $\begin{array}{l}\text { A language is best learnt by separately learning } \\
\text { language areas such as grammar, phonology, and } \\
\text { vocabulary }\end{array}$ & SA & A & $\mathrm{N}$ & $\mathrm{D}$ & SD \\
\hline 44. & $\begin{array}{l}\text { A language consists of social and cultural elements as } \\
\text { well as linguistic elements }\end{array}$ & SA & A & $\mathrm{N}$ & $\mathrm{D}$ & $\mathrm{SD}$ \\
\hline 45. & The best way to learn a language is to study it & $\mathrm{SA}$ & A & $\mathrm{N}$ & $\mathrm{D}$ & SD \\
\hline 46. & The best way to learn a language is to use it & SA & $\mathrm{A}$ & $\mathrm{N}$ & $\mathrm{D}$ & SD \\
\hline 47. & $\begin{array}{l}\text { The teacher should only use English duripg English } \\
\text { language classes }\end{array}$ & SA & A & $\mathrm{N}$ & $\mathrm{D}$ & SD \\
\hline 48. & $\begin{array}{l}\text { Dialogs included in textbooks should be practiced each } \\
\text { lesson }\end{array}$ & SA & A & $\mathrm{N}$ & $\mathrm{D}$ & SD \\
\hline 49. & $\begin{array}{l}\text { Speaking and listening skills should be learnt before } \\
\text { reading and writing }\end{array}$ & SA & A & $\mathrm{N}$ & $\mathrm{D}$ & SD \\
\hline 50. & The teacher should explain grammar clearly & SA & A & $\mathrm{N}$ & $\mathrm{D}$ & $\mathrm{SD}$ \\
\hline 51. & $\begin{array}{l}\text { The language learner has more responsibility for his or } \\
\text { her learning than the teacher }\end{array}$ & SA & A & $\mathrm{N}$ & $\mathrm{D}$ & $\mathrm{SD}$ \\
\hline 52 & It is good for students to make language errors & SA & A & $\mathrm{N}$ & D & $\mathrm{SD}$ \\
\hline 53. & $\begin{array}{l}\text { The language teacher should teach at a level just a little } \\
\text { higher than I am at }\end{array}$ & SA & A & $\mathrm{N}$ & $\mathrm{D}$ & $\mathrm{SD}$ \\
\hline 54. & $\begin{array}{l}\text { Reading, Writing, Speaking and Listening are equally } \\
\text { important language skills }\end{array}$ & SA & A & $\mathrm{N}$ & $\mathrm{D}$ & SD \\
\hline 55. & $\begin{array}{l}\text { During class. I should practice using the English } \\
\text { language with small groups of other students }\end{array}$ & SA & A & $\mathrm{N}$ & $\mathrm{D}$ & SD \\
\hline 56. & $\begin{array}{l}\text { Students should repeat words and sentences after the } \\
\text { teacher }\end{array}$ & SA & A & $\mathrm{N}$ & $\mathrm{D}$ & SD \\
\hline 57. & I prefer to work out language rules by myself & SA & A & $\mathrm{N}$ & $\mathrm{D}$ & SD \\
\hline 58. & Education is learning how to learn & SA & A & $\mathrm{N}$ & $\mathrm{D}$ & SD \\
\hline 59. & $\begin{array}{l}\text { Students should feel free to interrupt the teacher with } \\
\text { questions and comments at any time }\end{array}$ & SA & A & $\mathrm{N}$ & $\mathrm{D}$ & $\mathrm{SD}$ \\
\hline 60. & Education occurs primarily through extensive reading & SA & A & $\mathrm{N}$ & $\mathrm{D}$ & SD \\
\hline 61. & Students should choose what they learn in school & SA & A & $\mathrm{N}$ & $\mathrm{D}$ & SD \\
\hline 62. & The aim of education is to get a good job & SA & A & $\mathrm{N}$ & $\mathrm{D}$ & $S D$ \\
\hline
\end{tabular}


谢谢您抽空填写这份有关语言学习的问卷. 这是一位就读波特兰(美国 俄勒㐫州的波特兰)州立大学的研究生针对中国学生学习英文的方法和 学习英文的目的所做的一分调查，您的回答将有助于本研究之进行 请勿在问卷上署名. 以便问卷调查以不计名方式进行. 这些问题没有标准 答案.请依自己情况回答. 这份问卷也不会影响您的学习成绩. 如果您不愿 意回答.请把问卷交 回老师. 这项调查是自愿的.

填写这份问卷大约需要十五至二十分钟.

我已经看过和了解以上说明，并且同意填写问卷.

同意(请圈选): 是 否

填写问卷日期:

再次谢谢您.

指导教授 Dr. M. Terdal Kirsten Ngon 敬上

假如您对这有建议或问题, 请联络:

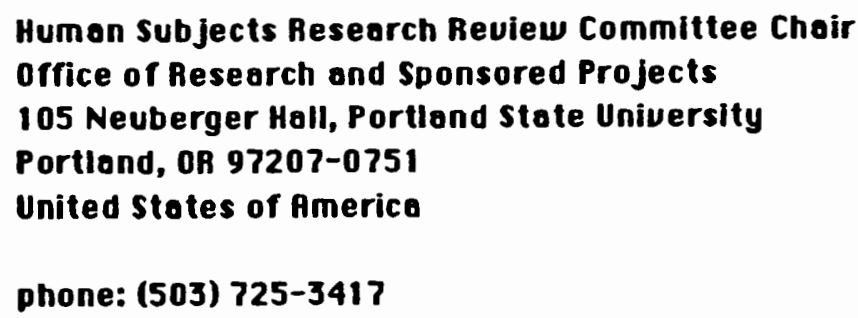


以下的问题. 请造选合您的答案(可以复选)，或在空白处写下柋的回答.

1. 然的年龊

2. 您的别

3. 您最早在家中所学的语言 (方言) 是那一种?

男

女

4. 除了上述语言外，您还会那些语言?

5. 您就读那一所大学?

6. 到目前为止，想一共在大学(包括研究所) 学习了几年?

7. 您总共学了几年英文?

8. 您认为白己的英文程度如何?

9. 您目前在准备托福，GAE或 GMAT 考试㫟?

100. 袋曾经有被外籍老师(英语系国家) 教过英文的经历吗?

普通话其他中 品䁁以外的

100. 如果有的话，那位老师(那些老师)的教 学方法和其他中国老师的方洼是相似。 呢? 还是不同呢?

11. 热是英语系的学生吗?

是

否

12. 在下列那些学科或专业中，您会需要用到英文?(可复选)
(s) 行政管理
(b) 军队
(c) 商业贸易
(d) 计拏机
(e) 教育
(n) 工程
(g) 人文科学
(n) 数学
(ii) 医学
(J) 科学
(k) 服务业
(I) 社会科学
(m) 其他:

\begin{tabular}{|c|c|c|c|c|c|c|c|c|}
\hline \multirow{2}{*}{$\frac{\text { 蕃齐 }}{\text { 埕 }}$} & \multicolumn{3}{|c|}{ 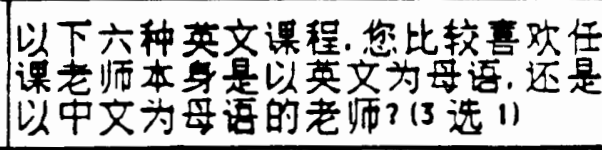 } & \multirow{2}{*}{\multicolumn{2}{|c|}{\begin{tabular}{|l} 
19.英文 \\
课程
\end{tabular}}} & \multicolumn{3}{|c|}{ 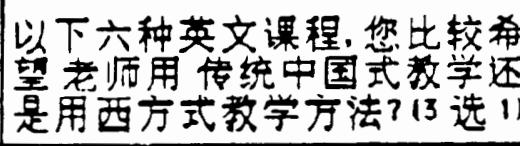 } \\
\hline & 中文 & 英文 & 都可以 & & & 中国式 & 西式 & 都可以 \\
\hline 写 & 中文 & 英文 & 都可以 & 20 & 写 & 中国式 & 西式 & 都可以 \\
\hline 说 & 中文 & 英文 & 都可以 & 21 & 说 & 中国式 & 西式 & 都可以 \\
\hline 听 & 中文 & 英文 & 都可以 & 22 & 听 & 中国式 & 西式 & 都可以 \\
\hline 语法 & 中文 & 英文 & 都可以 & 23 & 语法 & 中国式 & 西式 & 都可以 \\
\hline 文学 & 中文 & 英文 & 都可以 & 29 & 文学 & 中国式 & 西式 & 都可以 \\
\hline
\end{tabular}


下面有十六个句子，分别叙述学习英文的目的，请您依照自己的情况，国选下列叙述 对您的重要性，以及这些情说出现在您身上的频率。

\begin{tabular}{|c|c|c|c|c|c|}
\hline 重要性: & 1 -二点也 & $\begin{array}{l}2 \text { 2-丕很 } \\
\text { 重要 }\end{array}$ & 3-重要 & 4=很 & $5=$ 韭常 \\
\hline 出现频率: & 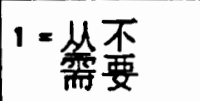 & 2= 很䒚 & 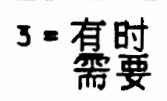 & 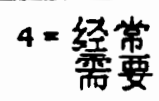 & $5=$ 总是是 \\
\hline
\end{tabular}

举例: 我需要阅读英文书籍

如果能够阅读英文书对您来说是很重要的。请您在下列重要性程度表中国选

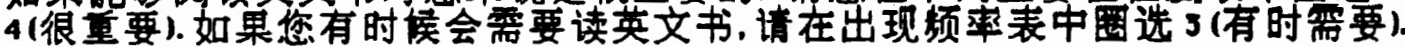

\begin{tabular}{|c|c|c|c|c|c|c|c|c|c|c|c|}
\hline & & & & 要出 & & & & 出王 & 级项 & & \\
\hline & & 不 & 䆖 & & & 韭要 & 㝝要 & & & & 碁基 \\
\hline 25. & 我需要阅读英文书籍 & 1 & 2 & 3 & 4 & 5 & 1 & 2 & 3 & 4 & 5 \\
\hline 26 . & 我需要用英文书写 & 1 & 2 & 3 & 4 & 5 & 1 & 2 & 3 & 4 & 5 \\
\hline 27. & 我需 要用英文做口语表达 & 1 & 2 & 3 & 4 & 5 & 1 & 2 & 3 & 4 & 5 \\
\hline 28. & 我需要听箽英文 & 1 & 2 & 3 & 4 & 5 & 1 & 2 & 3 & 4 & $\mathbf{5}$ \\
\hline 29. & 我使用英文和一群人讨论 & 1 & 2 & 3 & 4 & 5 & 1 & 2 & 3 & 4 & 5 \\
\hline 30. & 我用英文和一些人做一对 & 1 & 2 & 3 & 4 & 5 & 1 & 2 & 3 & 4 & 5 \\
\hline 31. & 我使用英文与英语系国家的人交谈 & 1 & 2 & 3 & 4 & 5 & 1 & 2 & 3 & 4 & $\mathbf{5}$ \\
\hline 32. & 我使用英文和非英语系国家的人交谈 & 1 & 2 & 3 & 4 & 5 & 1 & 2 & 3 & 4 & 5 \\
\hline 33. & 我需要使用英文传递信息 & 1 & 2 & 3 & 4 & 5 & 1 & 2 & 3 & & $\mathbf{5}$ \\
\hline 34. & 我需要英文来接收信息 & 1 & 2 & 3 & 4 & 5 & 1 & 2 & 3 & 4 & 5 \\
\hline 35. & 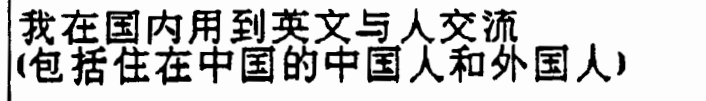 & 1 & 2 & 3 & 4 & 5 & 1 & 2 & 3 & 4 & 5 \\
\hline 36. & $\begin{array}{l}\text { 我使用到英文和住在国外的人交流 } \\
\text { (包括英语系和非英语系国) }\end{array}$ & 1 & 2 & 3 & 4 & 5 & 1 & 2 & 3 & & 5 \\
\hline 37. & 我因出国的关系,需要用到英文 & 1 & 2 & 3 & 4 & 5 & I & 2 & 3 & 4 & 5 \\
\hline 38. & 对我个人的教育来说，我需要用英文 & 1 & 2 & 3 & 4 & 5 & 1 & 2 & 3 & 4 & 5 \\
\hline 39. & 对我个人的自修来说, 我需要用英文 & 1 & 2 & 3 & 4 & 5 & 1 & 2 & 3 & 4 & 5 \\
\hline 40.1 & 在工作上.我需要用到英文 & & 2 & 3 & 4 & 5 & 1 & 2 & 3 & & \\
\hline
\end{tabular}


下面有二十二个叙述句. 请圈选您认同的程度

程度: 1 - 非常同意 2 - 同意 $3=$ 无特别意见 $4=$ 不同意 $5=$ 非常不同意

\begin{tabular}{|c|c|c|c|c|c|c|}
\hline & & 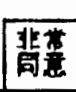 & 司童 & 覀鹤 & 甭 & 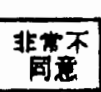 \\
\hline & 语言的目的是沟通 & 1 & 2 & 3 & 4 & 5 \\
\hline & 语言是许多规则的组合 & 1 & 2 & 3 & 4 & 5 \\
\hline 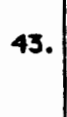 & 想要学习盆种语言，最好把文法，㕶音， & 1 & 2 & 3 & 4 & 5 \\
\hline 44. & 一种语言包含了社会.文化，以及语言学的因素在内 & 1 & 2 & 3 & 4 & 5 \\
\hline 5. & 熟读是学习一种语言最好的方法 & 1 & 2 & $\mathbf{3}$ & 4 & 5 \\
\hline 46. & 实际练卫是学习一种语言最好的方法 & 1 & 2 & 3 & 4 & 5 \\
\hline 47. & 英文课中,老师应该只用英文授课 & 1 & 2 & 3 & 4 & 5 \\
\hline . & 课本里的对话练习应该在每一堂课上都练习 & 1 & 2 & 3 & 4 & 5 \\
\hline 49. & 语言学习中的听和说练》应该摆在读和写之前 & 1 & 2 & 3 & 4 & 5 \\
\hline 50. & 语言老师有责任把语法解释清楚 & 1 & 2 & 3 & 4 & 5 \\
\hline & 对于学习语言的成果. 学生应负有比老师更多的责任 & 1 & 2 & 3 & 4 & 5 \\
\hline 52. & 语言学习的过程中, 犯错有时是有帮助的 & 1 & 2 & 3 & 4 & 5 \\
\hline 53. & 我的外语老师的上课难度，需要比我能掌握的深一点 & 1 & 2 & 3 & 4 & 5 \\
\hline 54. & 语言的听说读写四方面都同等重要 & 1 & 2 & 3 & 4 & 5 \\
\hline 55. & 在课堂上，我晋欢用英文和同学做小组讨论 & 1 & 2 & 3 & 4 & 5 \\
\hline 56. & 课堂上，学生应该跟着老师复述生字和例句 & 1 & 2 & 3 & 4 & 5 \\
\hline & 我比较亳欢自修语法 & 1 & 2 & 3 & 4 & 5 \\
\hline & 受教育实际上就是去学习研究方法 & 1 & 2 & 3 & 4 & 5 \\
\hline & 学生应该有权利随时发问和提出自己的意见 & 1 & 2 & 3 & 4 & 5 \\
\hline & 受教育主要是从厂泛阅读开始 & 1 & 2 & 3 & 4 & 5 \\
\hline 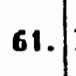 & 在学校里学生应该自由选课 & 1 & 2 & 3 & 4 & 5 \\
\hline & 教育的最终目的是找到一份好工作 & 1 & 2 & 3 & 4 & 5 \\
\hline
\end{tabular}




\title{
Teacher Questionnaire
}

Thank you for participating in this English language learning questionnaire. This research is being performed by a graduate student in Teaching English to Speakers of Other Languages (TESOL) at Portland State University (Portland, Oregon, United States of America). The study is investigating the ways that Chinese students prefer to learn English and to find out what English is needed for.

Your answers to these questions will be very helpful. Please do not write your name on the questionnaire so that you will remain anonymous. There are no right or wrong answers. If you do not wish to participate in this study you are not obliged to do so, participation is voluntary.

The questionnaire will take approximately 15-20 minutes to complete.

Thank you again

Dr. M. Terdal (teacher)

Kirsten Ngan (student)

Consent: $\quad$ 1. I have read and understood the above information and agree to take part in this study (circle one) Yes No Date:

2. Would you like to receive a summary of the results of this study? Yes No

If you have concerns or questions about this study, please contact:

\author{
Human Subjects Reseach Review Committee Chair \\ Office of Research and Sponsored Projects \\ 105 Neuberger Hall, Portland State University \\ Portland, OR 97207-0751 \\ United States of America \\ phone: +1 (503) 725-3417
}


Please circle the appropriate answer (s) or write an answer in the space provided:

1. Age in years

2. Sex

3. What is your native language?

\begin{tabular}{lll} 
Male & \multicolumn{2}{c}{ Female } \\
Mandarin & $\begin{array}{l}\text { A Chinese } \\
\text { dialect other } \\
\text { than Mandarin }\end{array}$ & $\begin{array}{l}\text { A language } \\
\text { other than }\end{array}$ \\
& Chinese.
\end{tabular}

4. What other languages do you know?

5. How many years did you study English?

6. How would you rate your proficiency in English?

poor fair average good very good

7. How many years did you study at a university?

8. What university are you teaching at?

9. How many years have you been teaching?

10a. Did you train to be a teacher in China:

$10 \mathrm{~b}$. If not, which country did you train in?

11a. Have you had a native English speaker teach you a Yes class about methods of teaching?

(go to question 13)

11b. If yes, have you used any of the new methods that Yes

No you were taught?

(go to question 13)

12a. If yes, which methods have you used?

$12 \mathrm{~b}$. Did the students respond well to these new methods? Yes

No

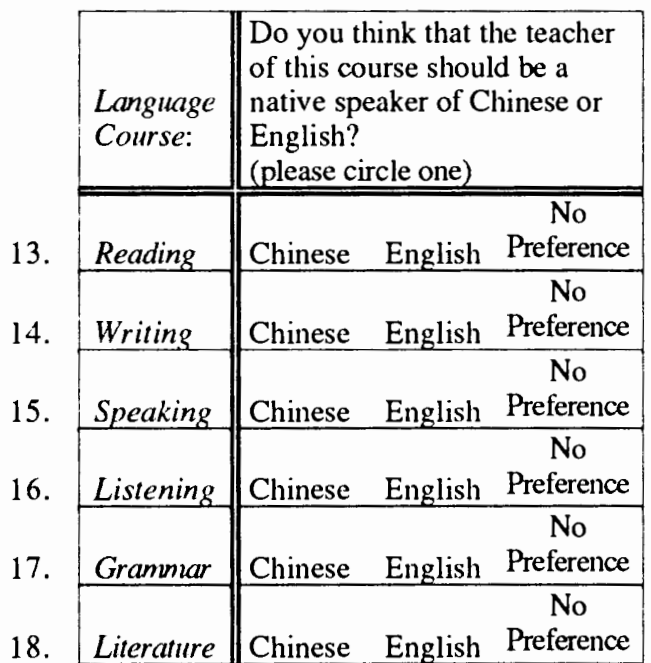

\begin{tabular}{|c|c|c|c|c|}
\hline \multirow[b]{2}{*}{19.} & $\begin{array}{l}\text { Language } \\
\text { Course: }\end{array}$ & \multicolumn{3}{|c|}{$\begin{array}{l}\text { Do you think that the teacher } \\
\text { of this course should use } \\
\text { Chinese teaching methods or } \\
\text { Western teaching methods*? } \\
\text { (please circle one) }\end{array}$} \\
\hline & Reading & Chinese & Western & $\begin{array}{c}\text { No } \\
\text { Preference }\end{array}$ \\
\hline 20. & Writing & Chinese & Western & $\begin{array}{c}\text { No } \\
\text { Preference }\end{array}$ \\
\hline & Speaking & Chinese & Western & $\begin{array}{c}\text { No } \\
\text { Preference }\end{array}$ \\
\hline & Listening & Chinese & Western & $\begin{array}{c}\text { No } \\
\text { Preference }\end{array}$ \\
\hline & Grammar & Chinese & Western & $\begin{array}{c}\text { No } \\
\text { Preference }\end{array}$ \\
\hline & Literature & Chinese & Western & $\begin{array}{c}\text { No } \\
\text { Preference }\end{array}$ \\
\hline
\end{tabular}

* nb: Chinese teaching methods may include traditional style lectures and memorisation. Western teaching methods may include interaction between students in class. 
Please answer the following questions by circling how intportant the action is to your students and how frequently you think they perform or will need to perform that action.

\begin{tabular}{|lllllll}
\hline Importance & $1=\begin{array}{l}\text { Not } \\
\text { important }\end{array}$ & $2=\begin{array}{l}\text { Not very } \\
\text { important }\end{array}$ & $3=\begin{array}{l}\text { Fairly } \\
\text { important }\end{array}$ & $4=\begin{array}{l}\text { Very } \\
\text { important }\end{array}$ & $5=\begin{array}{l}\text { Extremely } \\
\text { important }\end{array}$ \\
\hline Frequency & $1=$ Never & $2=$ Rarely & $3=$ Occasionally & $4=$ Often & $5=$ Always \\
\hline
\end{tabular}

For example: My students need to read English texts.

If it is very important for your students to read English texts, circle 4 (very important) on the Importance scale. If they read English texts occasionally, circle 3 (occasionally) on the Frequency scale.

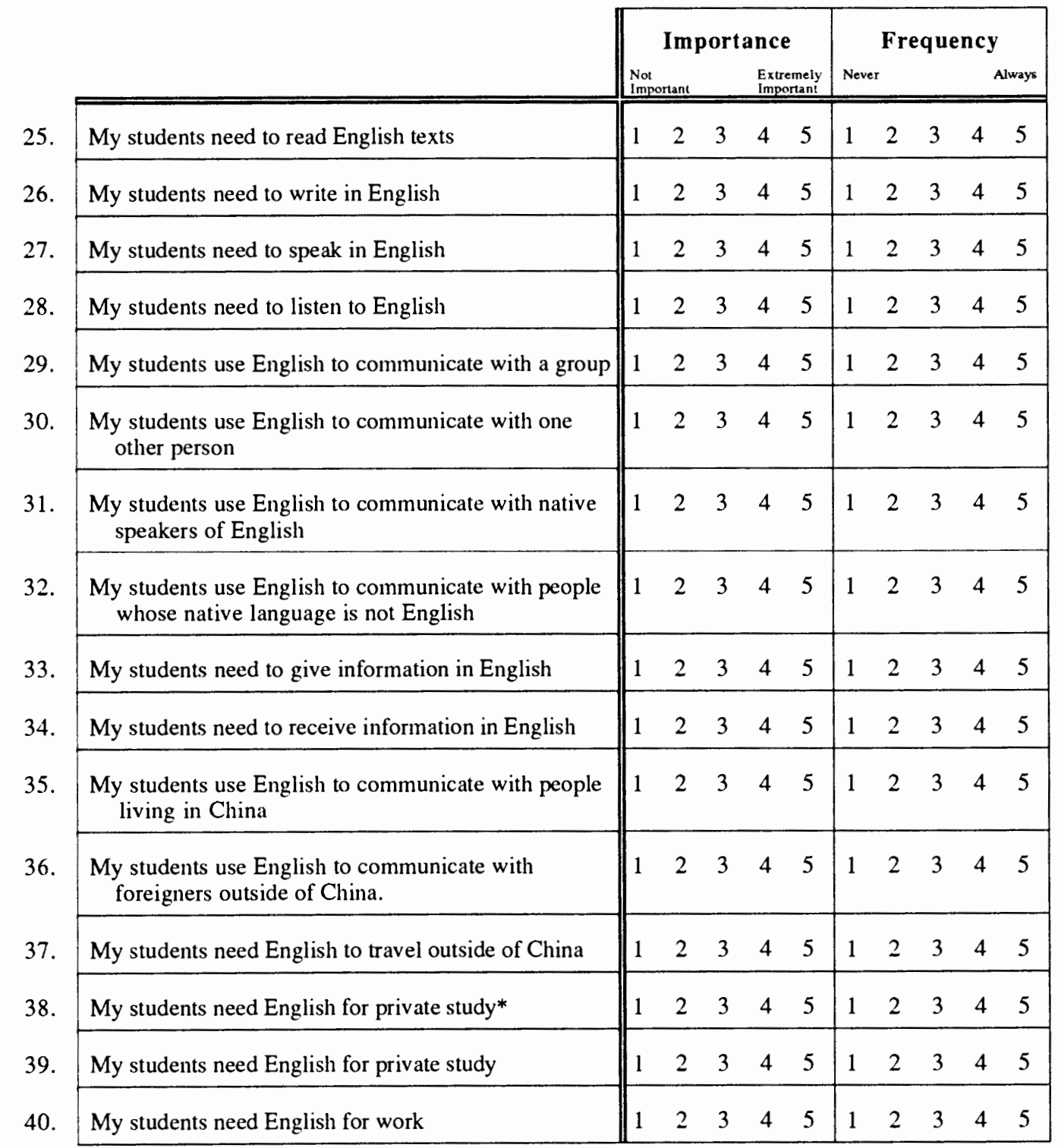

*This question was printed in error and should have read: "My students need English for their education" 
Please answer the following questions by indicating how much you agree or disagree with the statement.

\begin{tabular}{|c|c|c|c|c|c|c|}
\hline & & $\begin{array}{l}\text { Strongly } \\
\text { Agree }\end{array}$ & Agree & Neutral & Disagree & $\begin{array}{l}\text { Strongly } \\
\text { Disagree }\end{array}$ \\
\hline 41. & The purpose of language is communication & SA & $\mathrm{A}$ & $\mathrm{N}$ & $\mathrm{D}$ & SD \\
\hline 42. & A language is made up of many rules & SA & A & $\mathrm{N}$ & $\mathrm{D}$ & $S D$ \\
\hline 43. & $\begin{array}{l}\text { A language is best learnt by separately learning } \\
\text { language areas such as grammar, phonology, and } \\
\text { vocabulary }\end{array}$ & SA & A & $\mathrm{N}$ & $\mathrm{D}$ & $S D$ \\
\hline 44. & $\begin{array}{l}\text { A language consists of social and cultural elements as } \\
\text { well as linguistic forms }\end{array}$ & SA & A & $\mathrm{N}$ & $\mathrm{D}$ & $S D$ \\
\hline 45 . & The best way to learn a language is to study it & SA & A & $\mathrm{N}$ & $\mathrm{D}$ & $S D$ \\
\hline 46. & The best way to learn a language is to use it & SA & A & $\mathrm{N}$ & $\mathrm{D}$ & $S D$ \\
\hline 47. & $\begin{array}{l}\text { The teacher should only use English during English } \\
\text { language classes }\end{array}$ & SA & A & $\mathrm{N}$ & $\mathrm{D}$ & SD \\
\hline 48. & $\begin{array}{l}\text { Dialogs included in textbooks should be practiced each } \\
\text { lesson }\end{array}$ & SA & A & $\mathrm{N}$ & $\mathrm{D}$ & $S D$ \\
\hline 49. & $\begin{array}{l}\text { Speaking and listening skills should be learnt before } \\
\text { reading and writing }\end{array}$ & SA & A & $\mathrm{N}$ & $\mathrm{D}$ & SD \\
\hline 50. & The teacher should explain grammar clearly & SA & A & $\mathrm{N}$ & $\mathrm{D}$ & $\mathrm{SD}$ \\
\hline 51. & $\begin{array}{l}\text { The language learner has more responsibility for his or } \\
\text { her learning than the teacher }\end{array}$ & SA & A & $\mathrm{N}$ & $\mathrm{D}$ & SD \\
\hline 52 & It is good for students to make language errors & SA & A & $\mathrm{N}$ & $\mathrm{D}$ & SD \\
\hline 53. & $\begin{array}{l}\text { The language teacher should teach at a level just a little } \\
\text { higher than the student is at }\end{array}$ & SA & A & $\mathrm{N}$ & $\mathrm{D}$ & SD \\
\hline 54. & $\begin{array}{l}\text { Reading, Writing, Speaking and Listening are equally } \\
\text { important language skills }\end{array}$ & SA & A & $\mathrm{N}$ & $\mathrm{D}$ & $S D$ \\
\hline 55. & $\begin{array}{l}\text { During class, students should practice using the English } \\
\text { language with small groups or other students }\end{array}$ & SA & A & $\mathrm{N}$ & $\mathrm{D}$ & SD \\
\hline 56. & $\begin{array}{l}\text { Students should repeat words and sentences after the } \\
\text { teacher }\end{array}$ & SA & A & $\mathrm{N}$ & $\mathrm{D}$ & SD \\
\hline 57. & Students should work out language rules by themselves & SA & $\mathrm{A}$ & $\mathrm{N}$ & $\mathrm{D}$ & $S D$ \\
\hline 58. & Education is learning how to learn & SA & A & $\mathrm{N}$ & $\mathrm{D}$ & SD \\
\hline 59. & $\begin{array}{l}\text { Students should feel free to interrupt the teacher with } \\
\text { questions and comments at any time }\end{array}$ & SA & A & $\mathrm{N}$ & $\mathrm{D}$ & SD \\
\hline 60. & Education occurs primarily through extensive reading & SA & $\mathrm{A}$ & $\mathrm{N}$ & $\mathrm{D}$ & $\mathrm{SD}$ \\
\hline 61. & Students should choose what they learn & SA & $\mathrm{A}$ & $\mathrm{N}$ & $\mathrm{D}$ & SD \\
\hline 62. & The aim of education is for students to get a good job & SA & $\mathrm{A}$ & $\mathrm{N}$ & $\mathrm{D}$ & $\mathrm{SD}$ \\
\hline
\end{tabular}


APPENDIX C

CORRESPONDENCE WITH COORDINATORS 


\section{CORRESPONDENCE WITH COORDINATORS}

Excerpt One, Coordinator at Nankai University: "... Three teacher questionnaires were filled out by Chinese English teachers and 2 by American English teachers.... My students are 1st year Ph.D. students in a variety of fields (none in English), they come from all over China, some are young (early 20s), some are old (40s), and they are almost all male. I have only 8 women students and about 85 male students!..."

Excerpt Two, Coordinator at Hunan Medical University: "... The questionnaires enclosed are mostly done by my former students: undergraduate students of Hunan Medical University. They are of Grade 91 and the specialties are ranged from clinic medicine, preventative medicine, stomatology and library and medical information research. The students of Hunan Medical University (especially of Grade 91) have done a great good in the tests $(\mathrm{CET}=$ College English Tests)... I had a brief discussion with some of my colleagues on the questionnaires that you have offered. Besides I have compared your questionnaire with my own one that conducted last year.. The teachers that take part in the questionnaire program are chosen by my thorough consideration. They are of various opinions on teaching methods. I hope their views will give you a good understanding of our teachers stands in the L2 teaching methods. I myself didn't take part in the program... As for the form of your questionnaire, some of my colleagues show great interest on it. They would be very much pleased if you can tell them how you make out the questions and what is the theoretical foundation for them. They all said that your questionnaire will do help for their English teaching practice..." 
Excerpt Three, Coordinator at Anhui Medical University: _"... I

distributed your questionnaires to my colleagues and students right after the day I received them. All the teachers took the paper back to finish it, while about 35 students did it in class. I feel sorry that most of these 35 students are of intermediate or low level in English. Our two highest level classes have closed by the end of last semester, and I could only find about 15 students from these two classes to do the questionnaire... Another thing which I think you should take into consideration in studying the students' questionnaires is that most of the students of our university are from the rural area. Before entering into this university, they studied English only with textbook and an English teacher. And after graduation, most of them will have to go back to their hometown to work where English is seldemly (sic) used..." 


\section{APPENDIX D}

VARIATION BETWEEN DEMOGRAPHIC GROUPS RESPONSES TO QUESTIONNAIRE ITEMS 
VARIATION BETWEEN DEMOGRAPHIC GROUPS RESPONSES TO QUESTIONNAIRE ITEMS.

SECTION A: QUESTIONS 13-24.

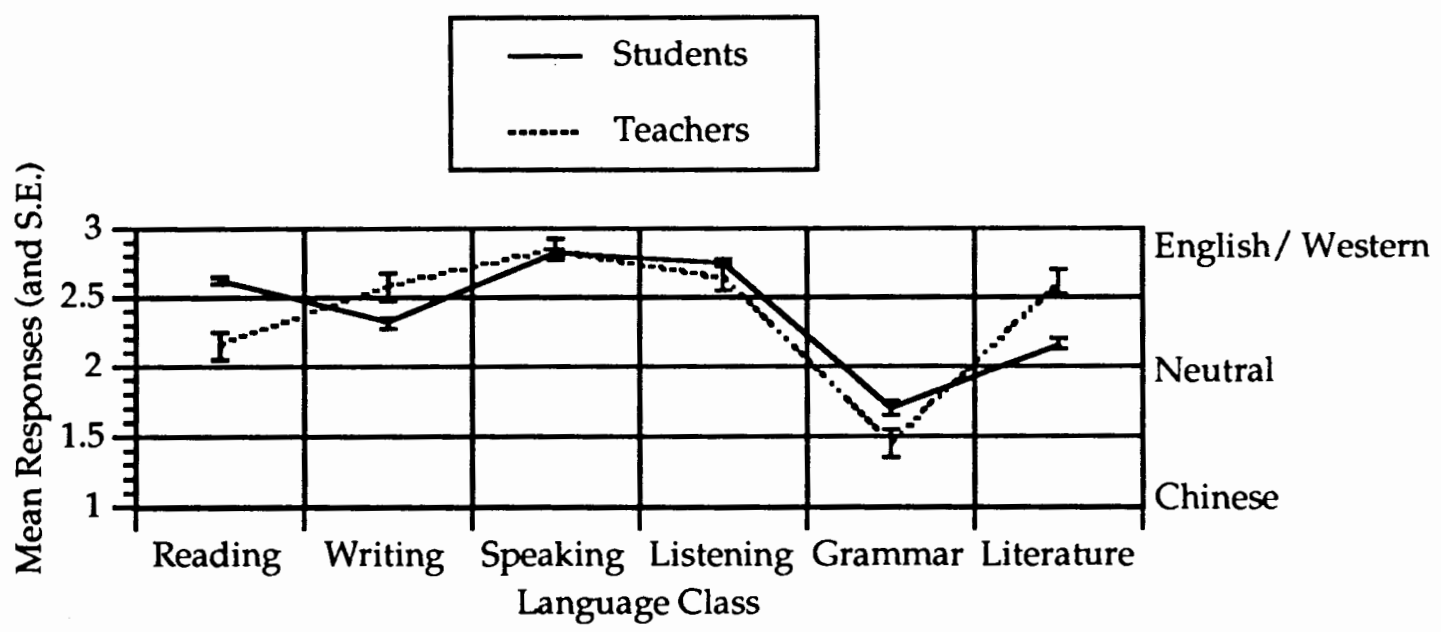

Figure A1. Students and Teachers preferences for teachers and methods.

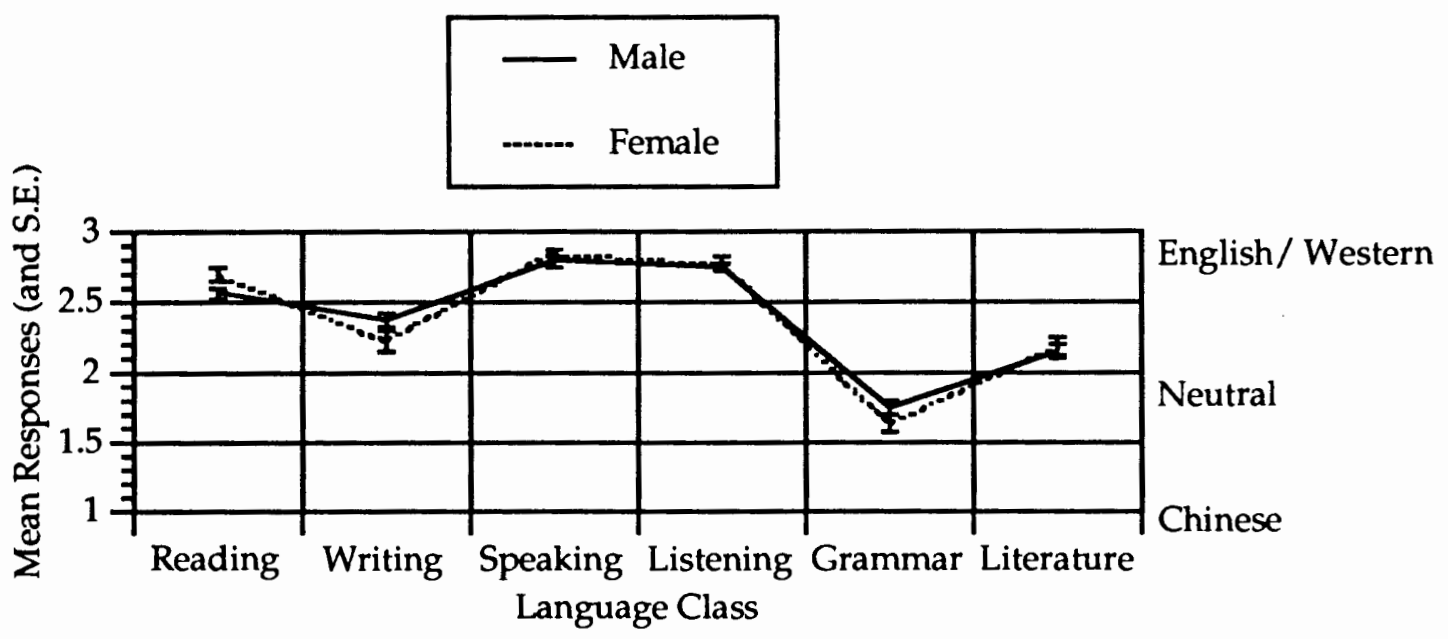

Figure A2. Male and Female students preferences for teacher and method. 


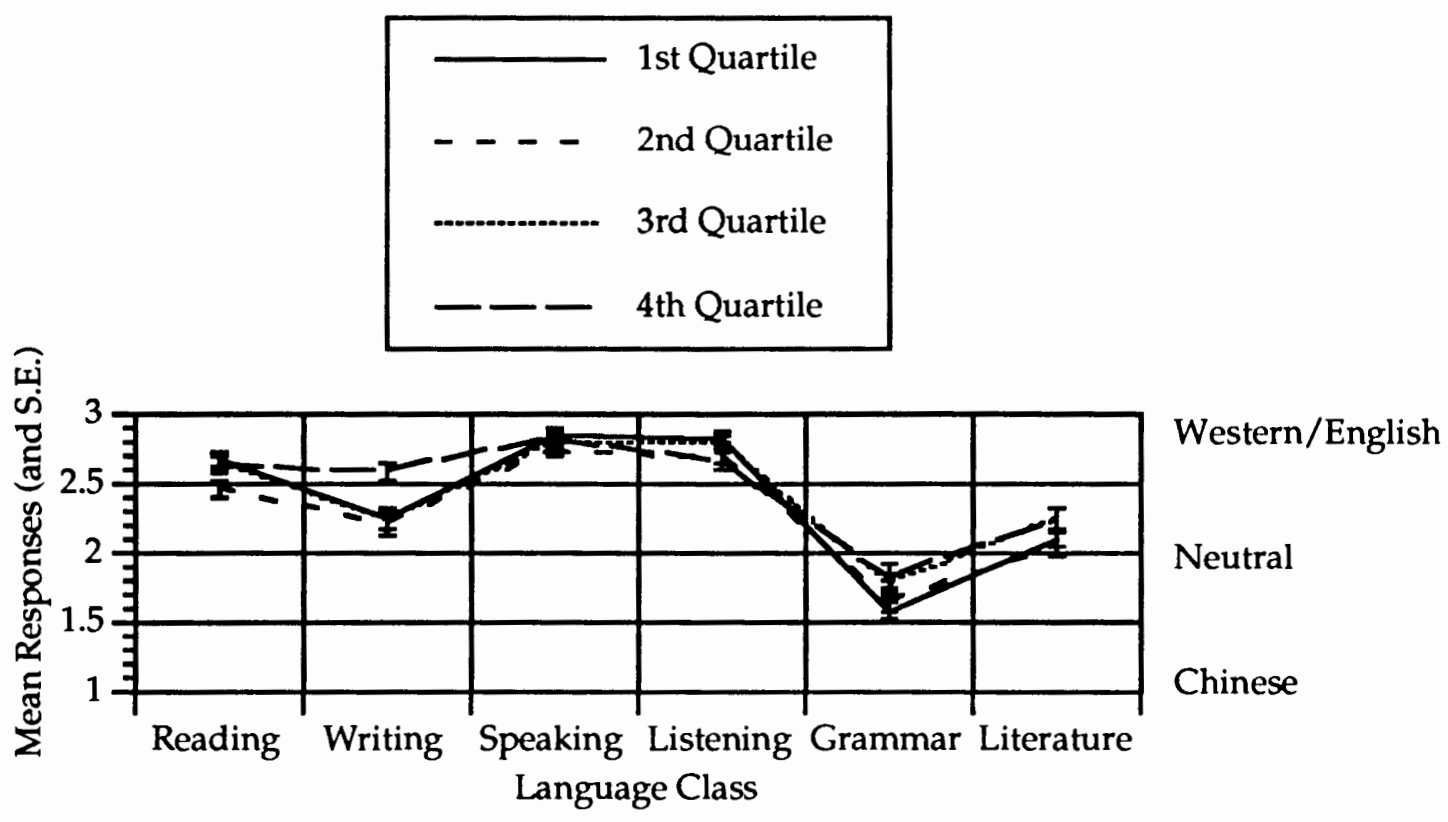

Figure A3. Preference for Teacher and Method based on age. Quartile 1 = students under 21. Quartile 2 = students 21-22 years. Quartile $3=$ students 22-23 years. Quartile $4=$ students over 23 years.

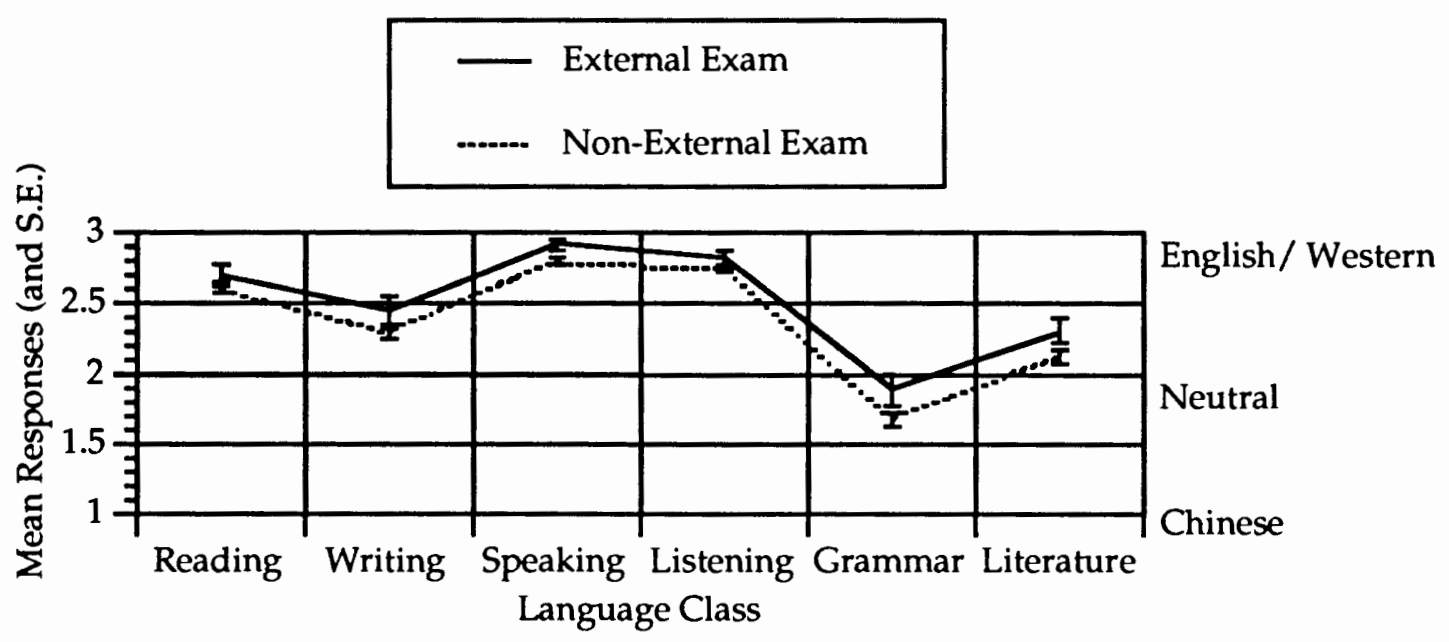

Figure A4. Preference for Teacher and Method based on whether students are sitting for an external exam or not. 


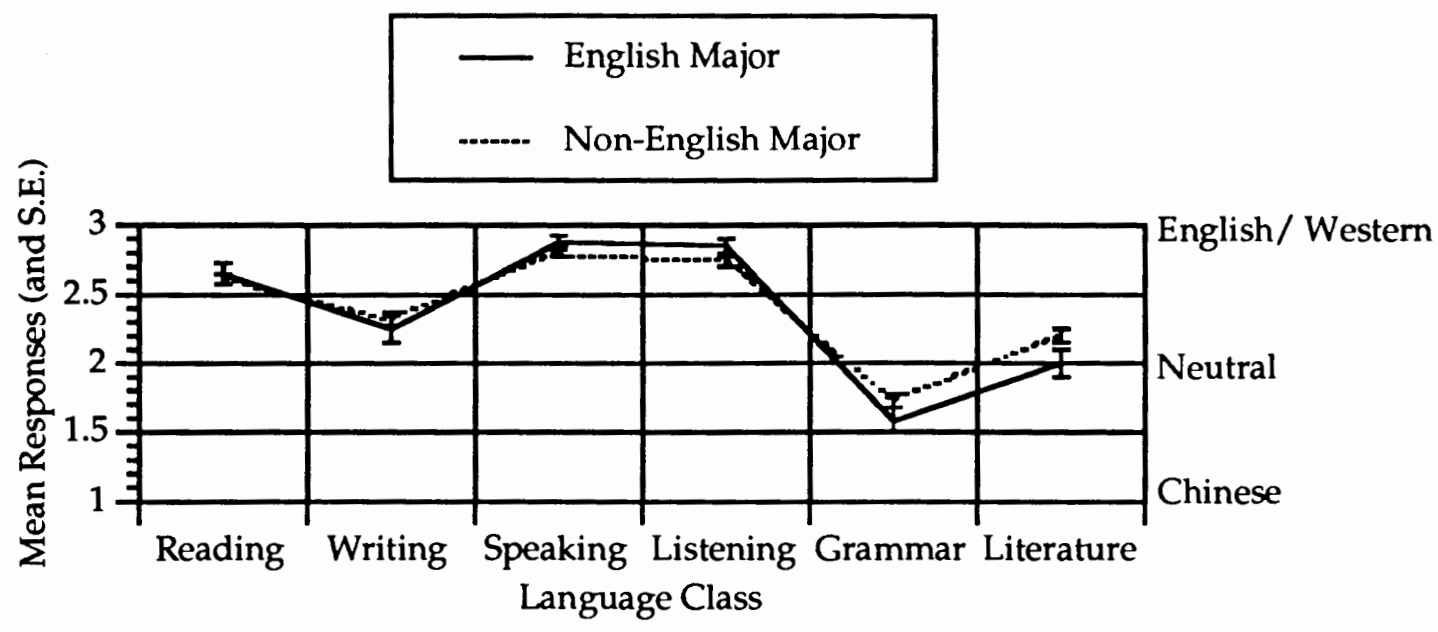

Figure A5. Preference for Teacher and Method based on whether a student was an English major or not.

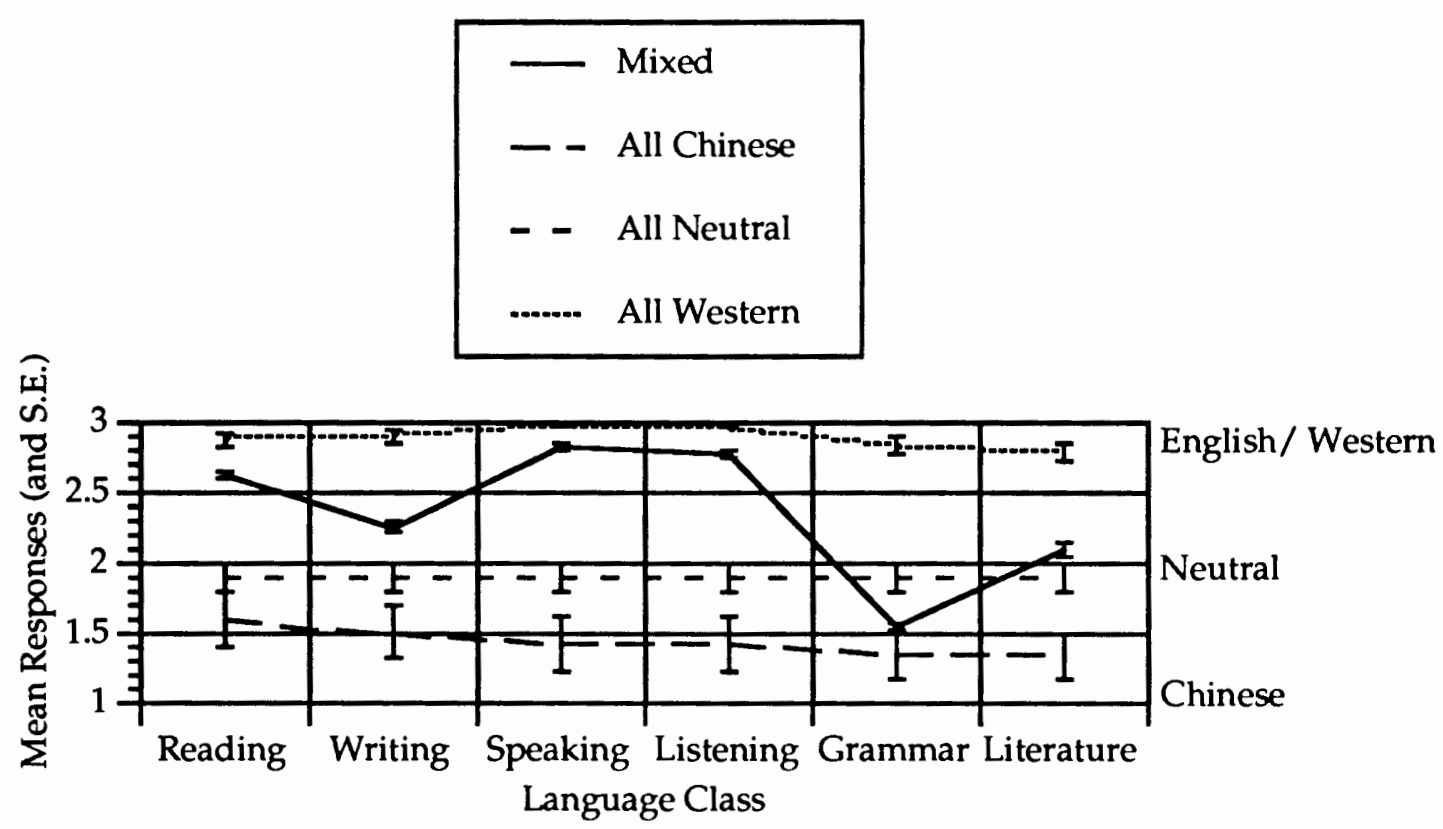

Figure A6. Preference for Teacher and Method based on students responses to questions 13-18. 

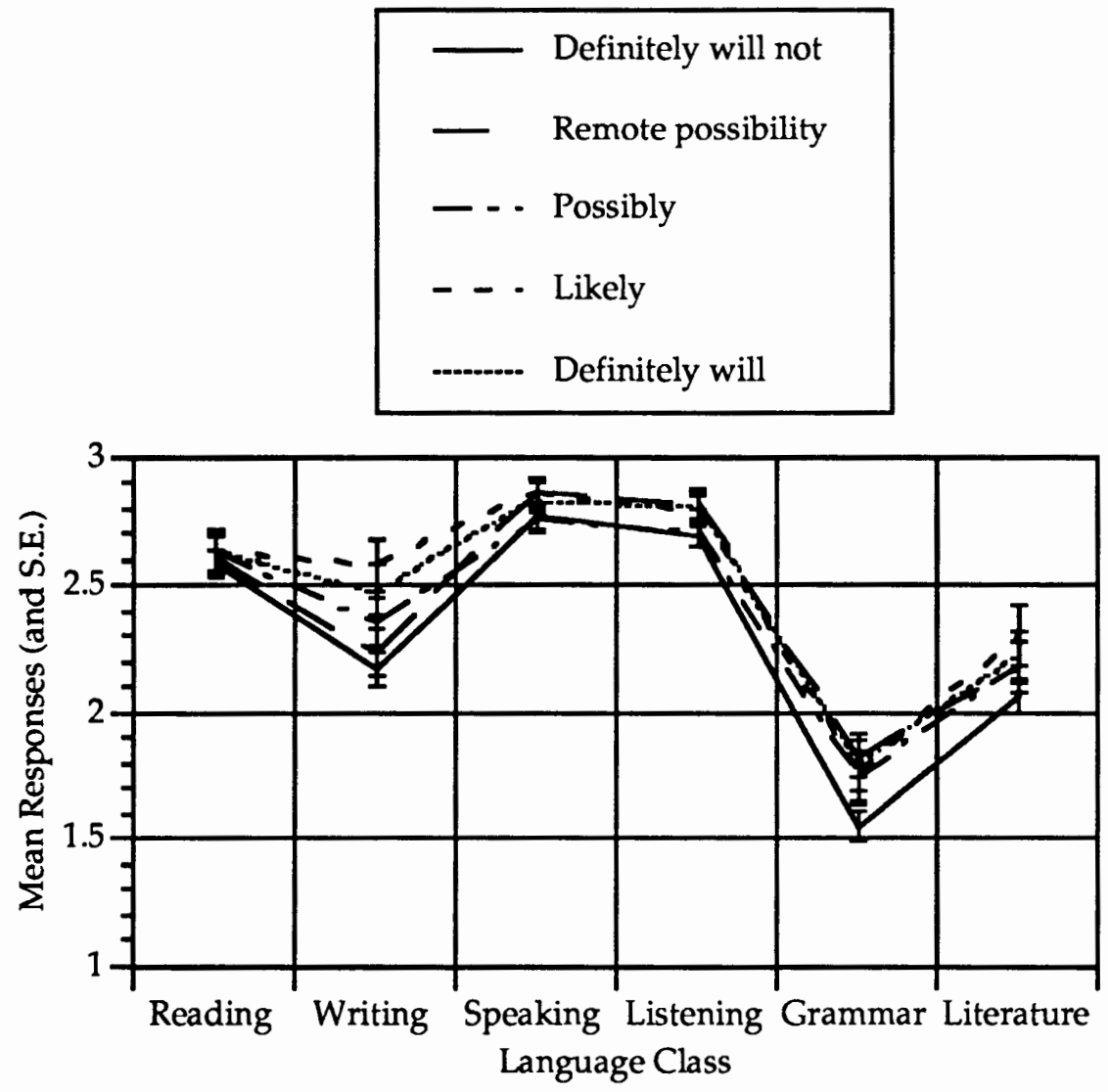

English/ Western

Neutral

Chinese

Figure A7. Preference for Teacher and Method based on how likely it is for a student to be going overseas. 
SECTION B: QUESTIONS 25-40.

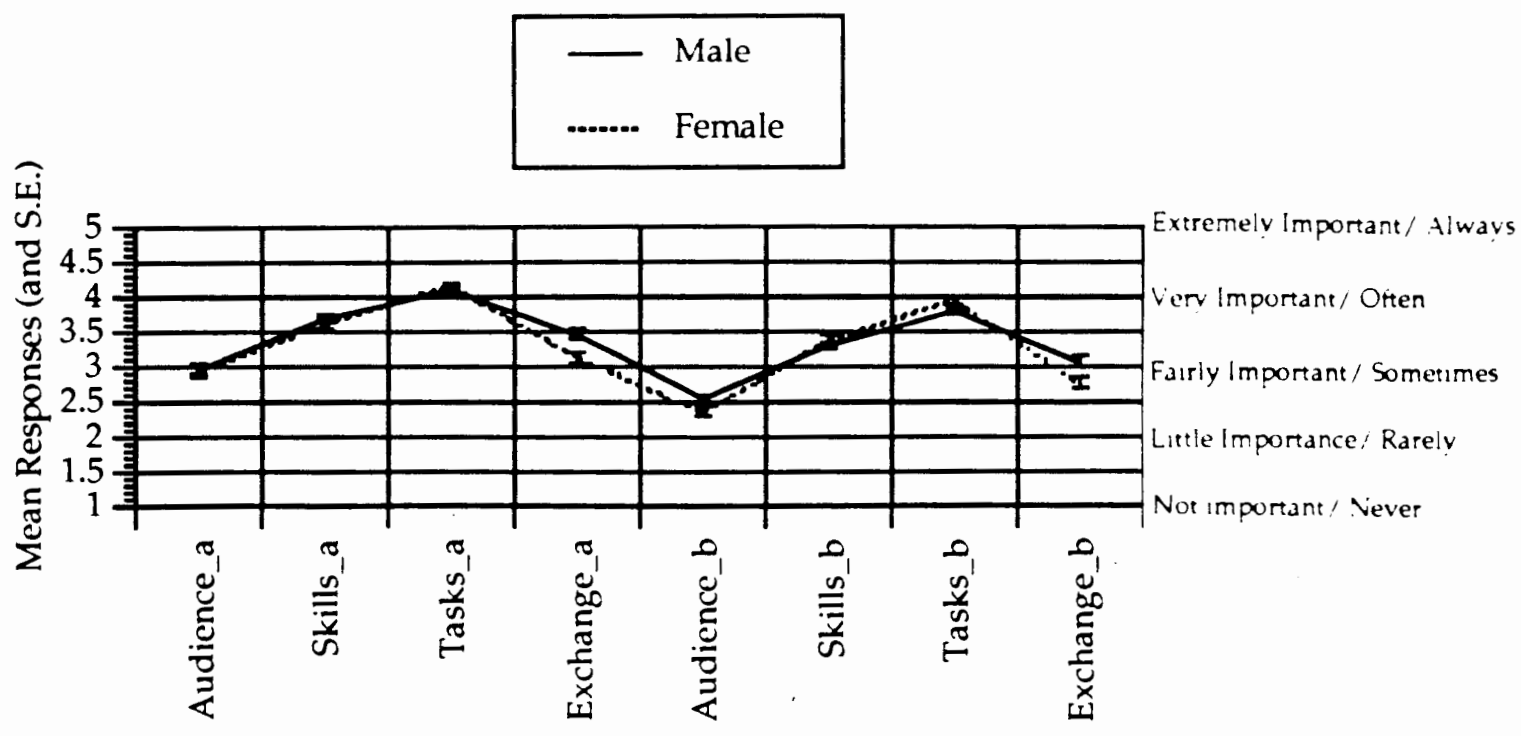

Factor groups for Importance and Frequency

Figure B1. Male and female students mean responses to the factor groups of questions $25-40$

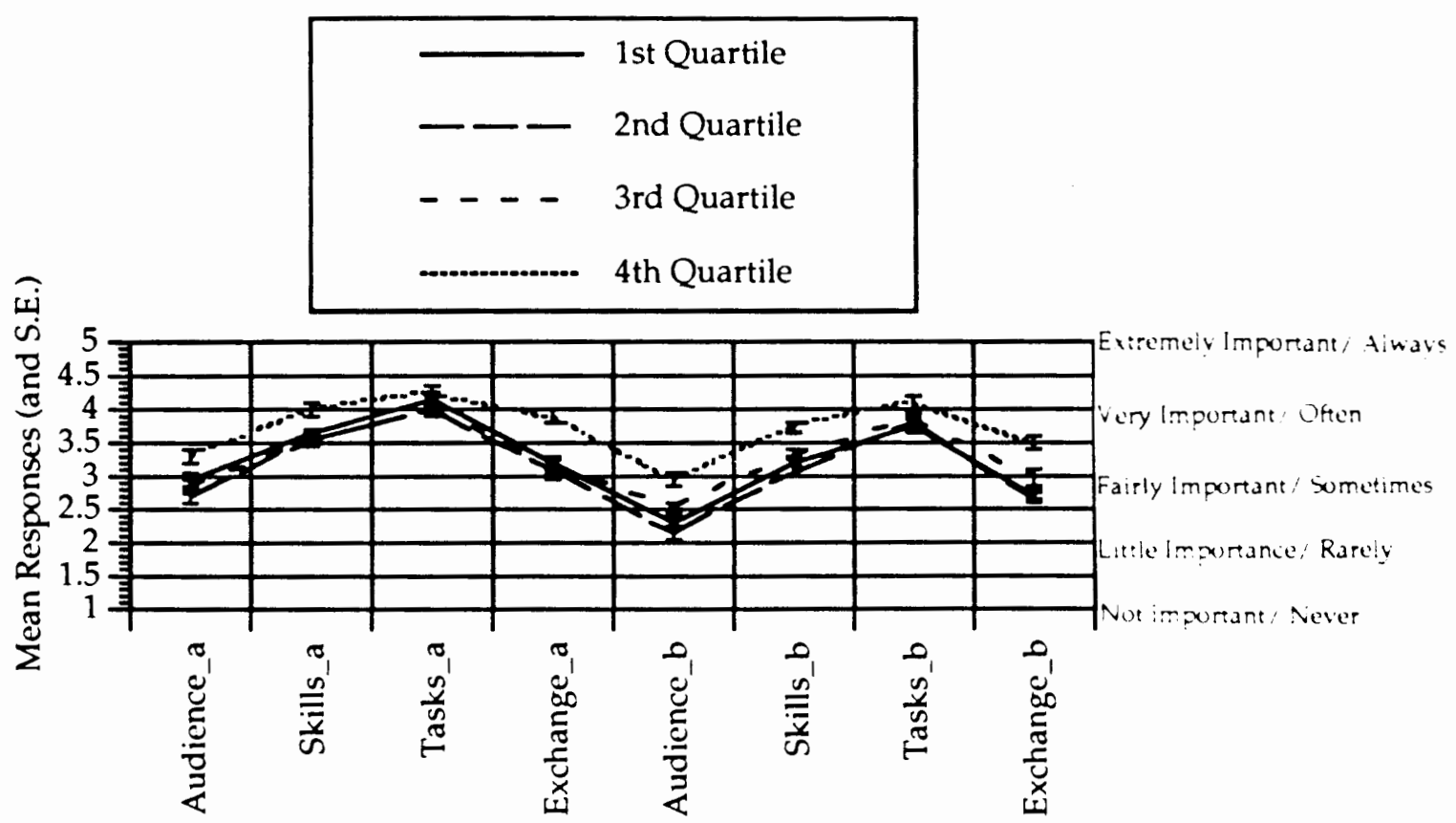

Factor groups for Information and Frequency

Figure B2. Mean responses to the factor groups of questions $25-40$ by age quartiles. Quartile $1=$ under 21 years, Quartile $2=21-22$ years, Quartile 3 $=22-23$ years, Quartile $4=$ over 23 years 


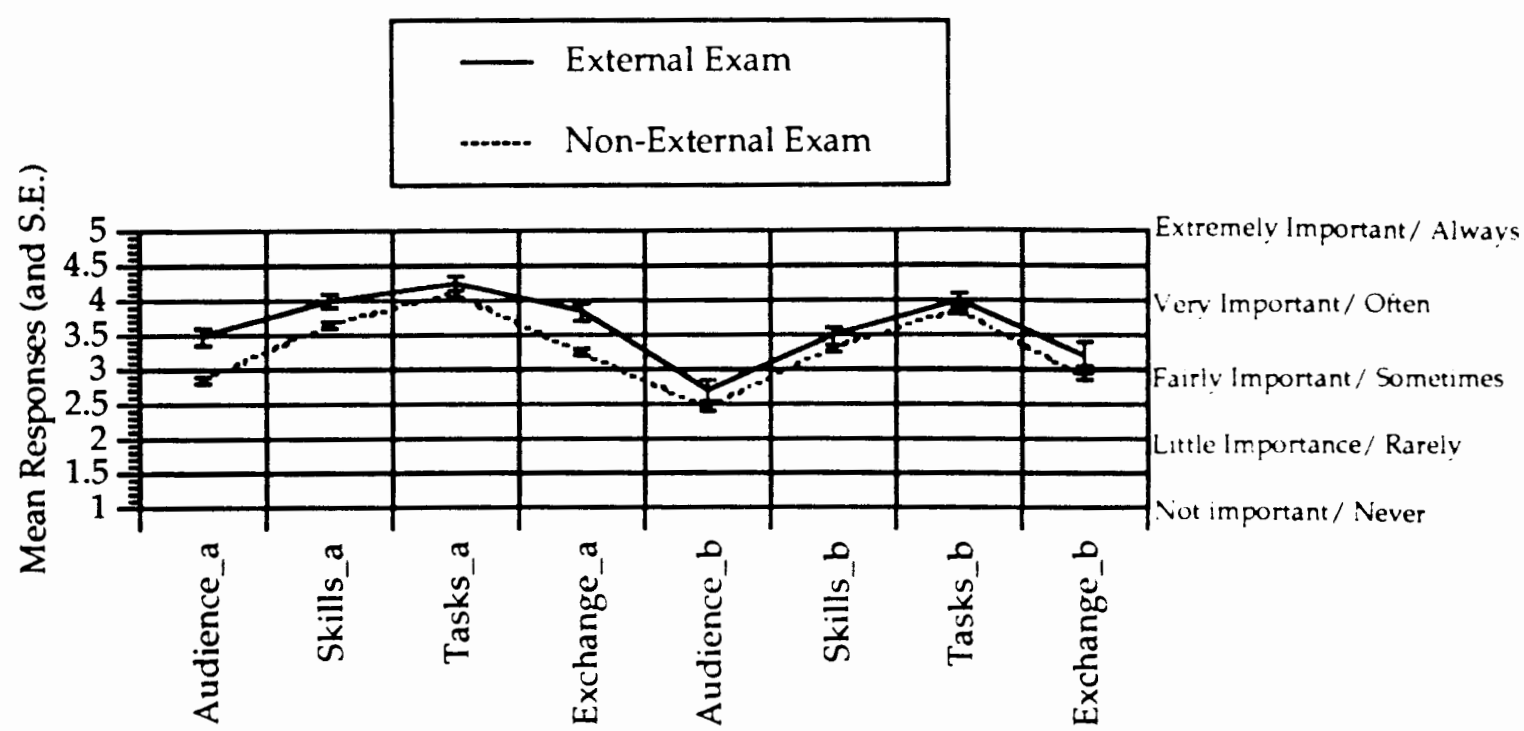

Factor groups for Information and Frequency

Figure B3. Mean responses to the factor groups of questions 25-40 according to whether students are sitting an external exam or not

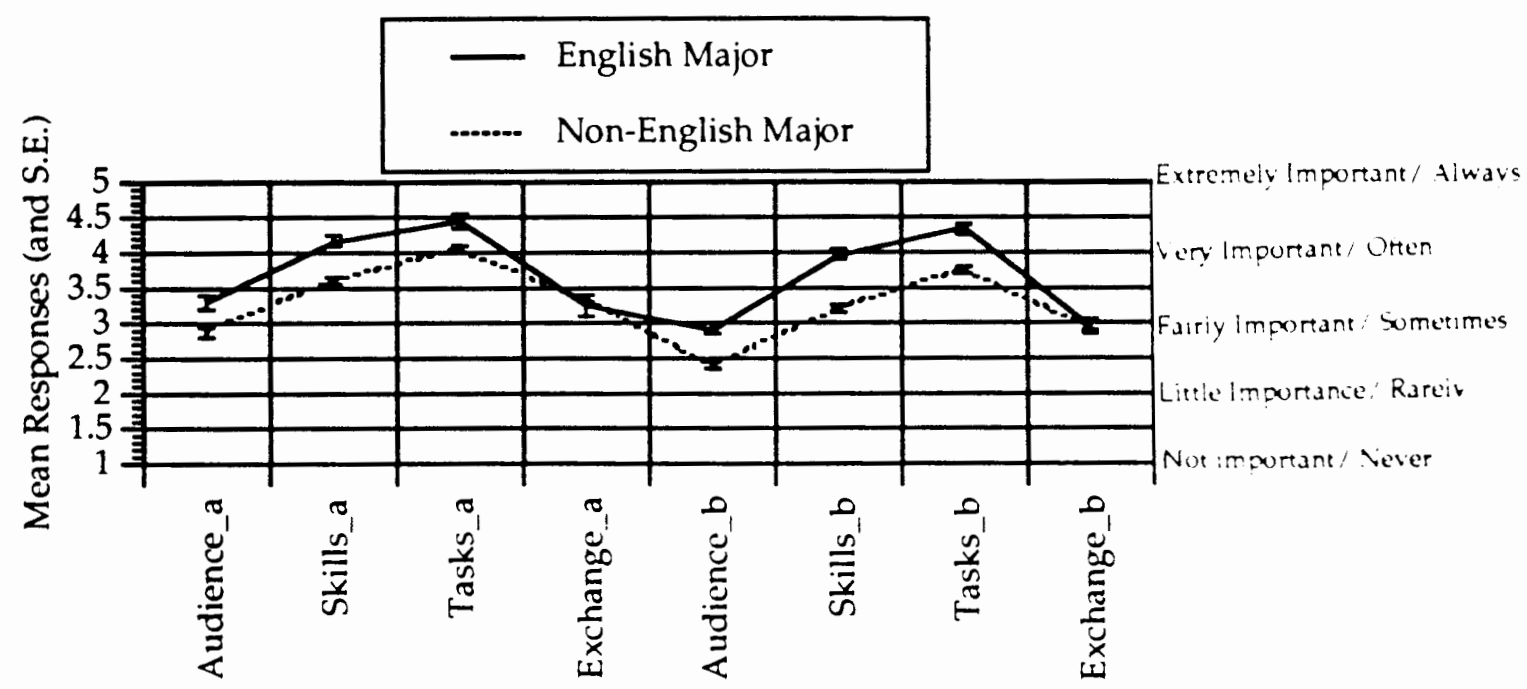

Factor groups for Information and Frequency

Figure B4. Mean responses to the factor groups of questions 25-40 according to whether or not students major subject is English 

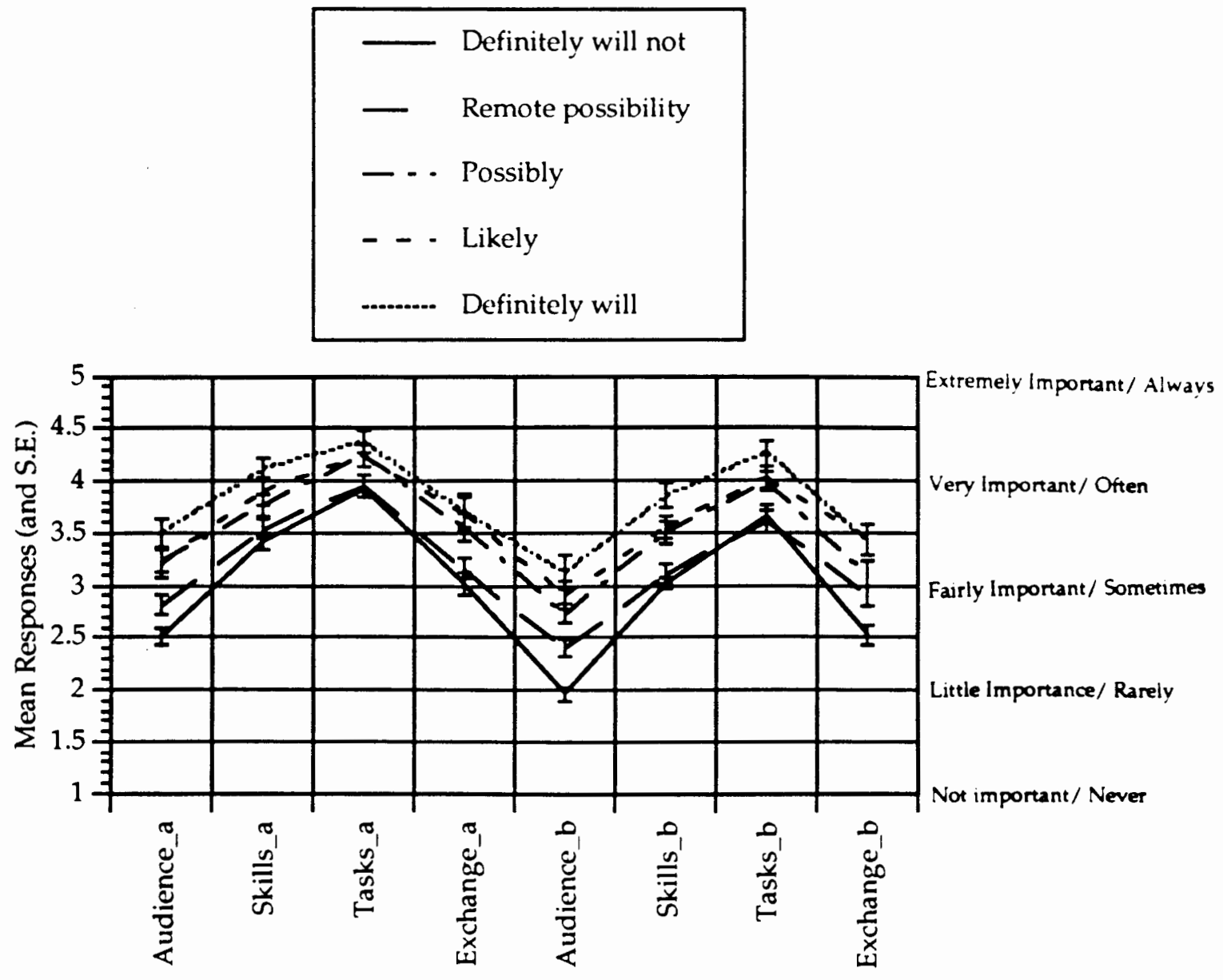

Factor groups for Importance and Frequency

Figure B5. Mean responses to the factor groups of questions 25-40 according to whether or not students are going overseas. 


\section{- Mixed \\ - All Chinese \\ - - All Neutral \\ All Western}

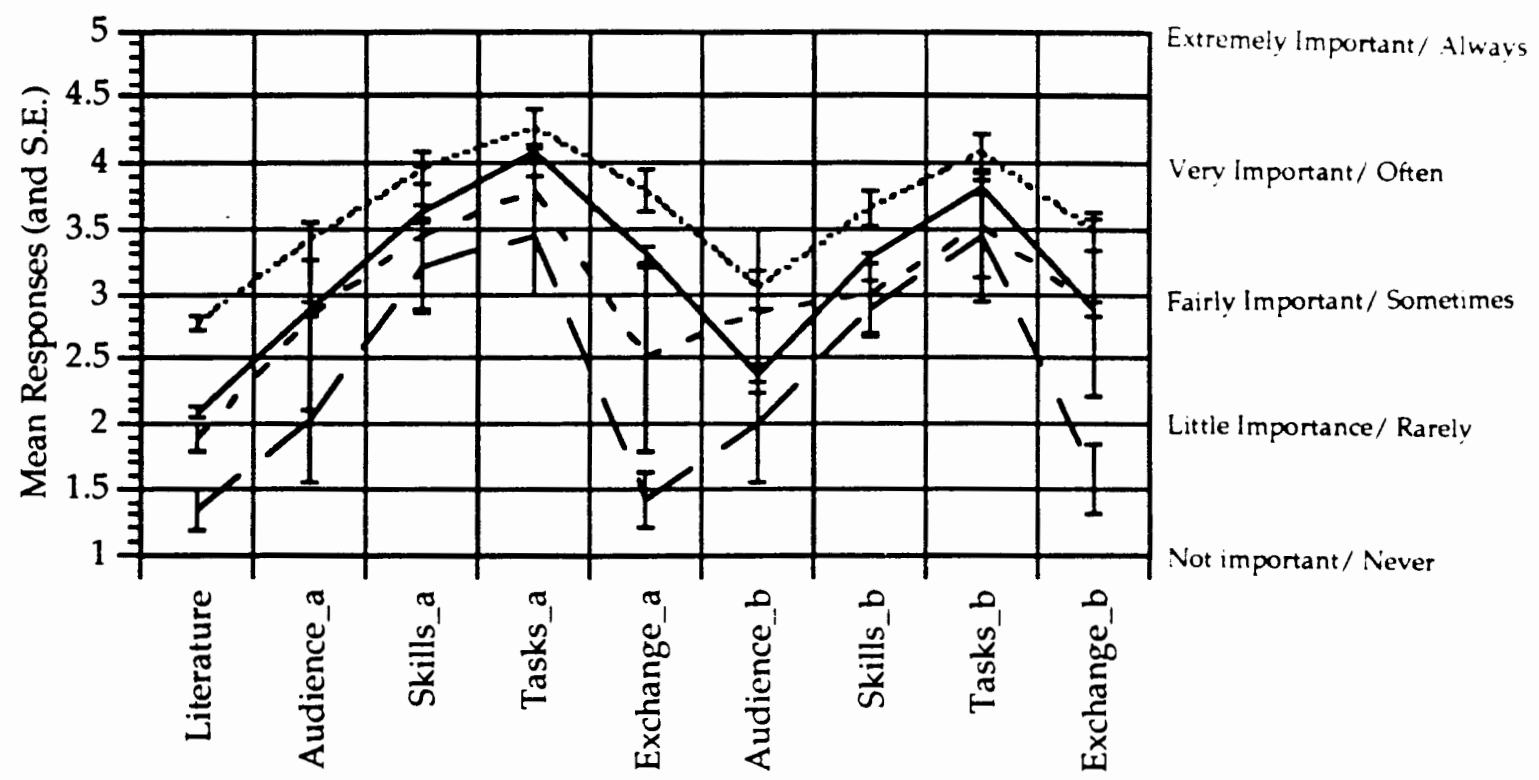

Factor groups for Importance and Frequency

Figure B6. Preferences for teacher (as shown by answers to questions 1318) and factor groups. 
APPENDIX E

TYPES OF QUESTIONS TO ASK ALONGSIDE OR INSTEAD OF QUESTIONS 41-62 
Please answer the following questions by indicating how much you agree or disagree with the statement.

\begin{tabular}{|c|c|c|c|c|c|}
\hline & s. A. & Agree & Neutral & Disagree & S.D. \\
\hline $\begin{array}{l}\text { I find it useful to repeat words and phrases after the } \\
\text { teacher. (A-L) }\end{array}$ & SA & $\bar{A}$ & $\mathbf{N}$ & $\overline{\mathrm{D}}$ & SD \\
\hline I like to practice using English in groups. (CA) & SA & A & $\mathbf{N}$ & $\mathrm{D}$ & SD \\
\hline $\begin{array}{l}\text { During class the teacher should speak most of the time. } \\
\text { (G-T, Comprehensive \& Cognitive) }\end{array}$ & SA & A & $\mathbf{N}$ & $\mathrm{D}$ & SD \\
\hline $\begin{array}{l}\text { During class, individual students should read sections of } \\
\text { the text to the class. (G-T) }\end{array}$ & SA & A & $\mathbf{N}$ & $\mathrm{D}$ & SD \\
\hline $\begin{array}{l}\text { I like to make up sentences in English that express my } \\
\text { thoughts (CA) (Holistic) }\end{array}$ & SA & A & $\mathbf{N}$ & $\mathrm{D}$ & SD \\
\hline $\begin{array}{l}\text { Translating sentences and passages from Chinese to } \\
\text { English and English to Chinese helps me to learn } \\
\text { English. (G-T) }\end{array}$ & SA & A & $\mathbf{N}$ & $\mathrm{D}$ & SD \\
\hline $\begin{array}{l}\text { I like to read long English texts to get an idea of the } \\
\text { content. (CA) }\end{array}$ & SA & A & $\mathbf{N}$ & $\mathrm{D}$ & SD \\
\hline $\begin{array}{l}\text { If I repeat a phrase enough times I will be able to use it } \\
\text { naturally. (A-L) (Stimulus-response) }\end{array}$ & SA & A & $\mathbf{N}$ & $\mathrm{D}$ & SD \\
\hline $\begin{array}{l}\text { Most students learn a language the same way (not } \\
\text { cognitive) }\end{array}$ & SA & A & $\mathbf{N}$ & $\mathrm{D}$ & SD \\
\hline I like to use English more than study it. (cognitive) & SA & A & $\mathbf{N}$ & $\mathrm{D}$ & SD \\
\hline Errors show that I am learning & SA & A & $\mathbf{N}$ & $\mathrm{D}$ & SD \\
\hline My personality affects how I learn English (Holistic) & SA & A & $\mathbf{N}$ & $\mathrm{D}$ & SD \\
\hline $\begin{array}{l}\text { Language classes should gradually move from simple } \\
\text { concepts to more difficult ones (stimulus-response) }\end{array}$ & SA & A & $\mathbf{N}$ & $\mathrm{D}$ & SD \\
\hline $\begin{array}{l}\text { Grammatical structures are more important than the } \\
\text { words which are put in those structures. (stimulus } \\
\text { response) }\end{array}$ & SA & A & $N$ & $\mathrm{D}$ & SD \\
\hline $\begin{array}{l}\text { I should be able to influence what we learn in English } \\
\text { classes. (rational-cognitive orientation) }\end{array}$ & SA & A & $\mathbf{N}$ & $\mathrm{D}$ & SD \\
\hline $\begin{array}{l}\text { I learn best when the teacher takes time to explain } \\
\text { things (not Behaviourist) }\end{array}$ & SA & A & $\mathrm{N}$ & $\mathrm{D}$ & SD \\
\hline I am responsible for what I leam (Humanistic) & SA & A & $\mathbf{N}$ & $\mathrm{D}$ & SD \\
\hline Education helps me to grow as a person. (Humanistic) & SA & A & $\mathbf{N}$ & $\mathrm{D}$ & SD \\
\hline
\end{tabular}

